
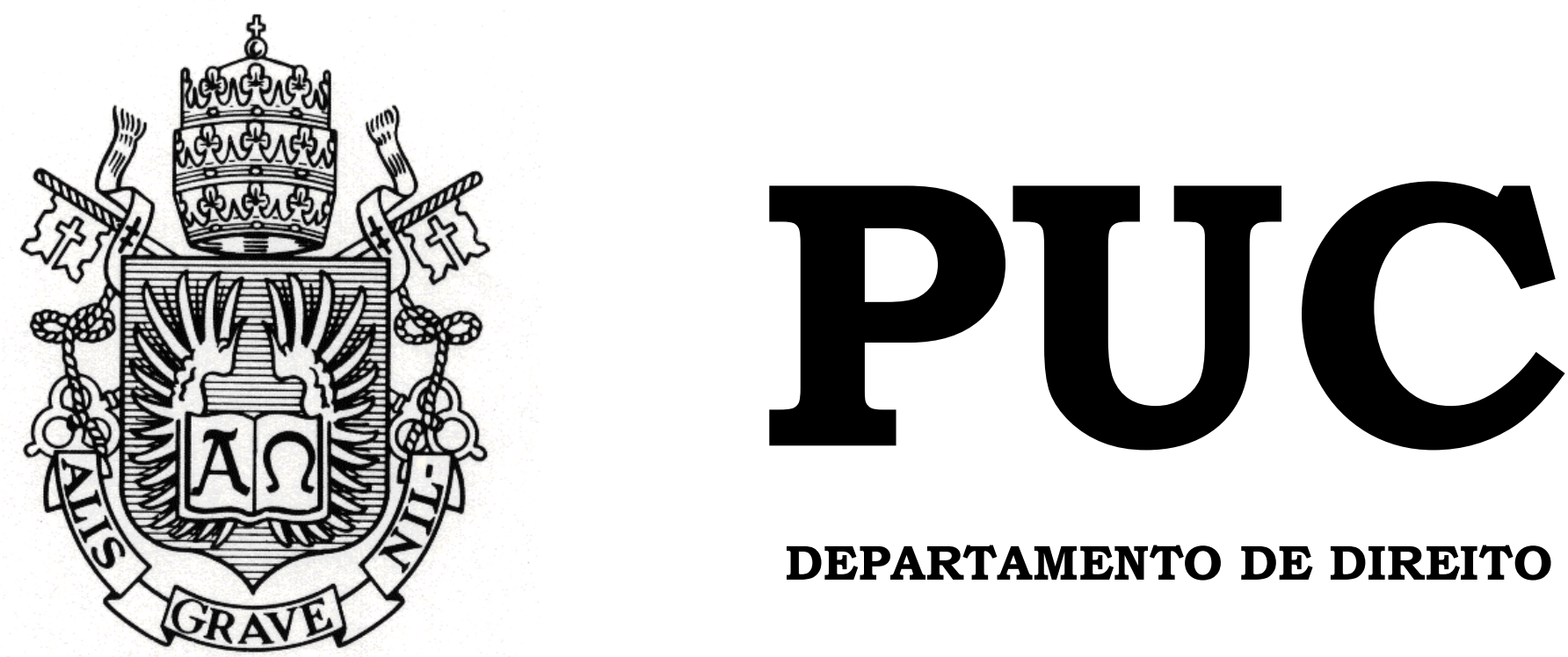

DEPARTAMENTO DE DIREITO

CONDUTAS ANTICOMPETITIVAS UNILATERAIS E VERTICAIS À LUZ DO DIREITO ANTITRUSTE BRASILEIRO

por

ALEXANDRE DE ALMEIDA CANALINI

ORIENTADOR: PEDRO PAULO SALLES CRISTOFARO 2018.1

PONTIFÍCIA UNIVERSIDADE CATÓLICA DO RIO DE JANEIRO

RUA MARQUÊS DE SÃO VICENTE, 225 - CEP 22453-900

RIO DE JANEIRO - BRASIL 


\section{CONDUTAS ANTICOMPETITIVAS UNILATERAIS E VERTICAIS À LUZ DO DIREITO ANTITRUSTE BRASILEIRO}

por

\section{ALEXANDRE DE ALMEIDA CANALINI}

Monografia apresentada ao Departamento de Direito da Pontificia Universidade Católica do Rio de Janeiro (PUC-Rio) como requisito parcial para obtenção do Título de Bacharel em Direito.

Orientador: Pedro Paulo Salles Cristofaro 
Todos os direitos reservados. É proibida a reprodução total ou parcial do trabalho sem autorização da universidade, do autor e do orientador.

\section{Alexandre de Almeida Canalini}

É mestre em Administração de Empresas pela PUC-Rio. Pós-graduado em Gestão Bancária pela Fundação Dom Cabral PUC-MG. Graduado em Administração de Empresas pela PUC-Rio. Atuou por doze anos no mercado financeiro em banco de investimento, nas áreas de crédito para corporate banking, internacional, corretora de valores e asset management. Atualmente é consultor de projetos pela FGV Projetos, professor da PUC-Rio, FGV e Ibmec.

Ficha Catalográfica

Canalini, Alexandre de Almeida

Condutas anticompetitivas unilaterais e verticais à luz do direito antitruste brasileiro / Alexandre de Almeida Canalini ; orientador: Pedro Paulo Salles Cristofaro. -2018.

148 f. : il. ; $30 \mathrm{~cm}$

Trabalho de conclusão de curso (graduação)Pontifícia Universidade Católica do Rio de Janeiro, Departamento de Direito, 2018.

Inclui bibliografia

1. Direito - TCC. 2. Direito antitruste. 3. Direito concorrencial. 4. Condutas anticompetitivas. 5. Obstrução à livre concorrência. 6. Abuso de posição dominante. I. Cristofaro, Pedro Paulo Salles. II. Pontifícia Universidade Católica do Rio de Janeiro. Departamento de Direito. III. Título. 
Para minha família pelo apoio ao longo da pesquisa. 


\section{Agradecimentos}

A Deus pela perseverança sempre presente ao longo do desenvolvimento da pesquisa.

Aos familiares que acompanharam e apoiaram a longa caminhada durante o curso.

Ao corpo docente da PUC-Rio que contribuiu não somente com o ensino das normas jurídicas, mas principalmente com a preocupação constante com o uso do direito como meio de construção de uma sociedade melhor.

Aos amigos do corpo discente que, nascidos em outra geração, ensinaramme com maestria como pensam os novos jovens.

Por fim, aos funcionários da PUC-Rio, do estacionamento à secretaria do Departamento de Direito. Todos são fundamentais para o ambiente de excelência acadêmica da Universidade. 


\section{Resumo}

Canalini, Alexandre de Almeida; Cristofaro, Pedro Paulo Salles. Condutas Anticompetitivas Unilaterais e Verticais à Luz do Direito Antitruste Brasileiro. Rio de Janeiro, 2018. 148p. Monografia - Departamento de Direito, Pontifícia Universidade Católica do Rio de Janeiro.

As condutas unilaterais e verticais são mais frequentemente objeto de preocupações e discussões em matéria de direito antitruste no exterior. No Brasil a autoridade antitruste tem dedicado a maior parte do tempo à análise dos acordos horizontais. Destarte, o objetivo do estudo foi compreender as características das condutas unilaterais e verticais consideradas ilícitas à luz do direito antitruste brasileiro. Foram realizadas pesquisas bibliográficas, dos julgados recentes pelo CADE e estudos de casos. Foram aplicados procedimentos estatísticos tanto para análise de frequência quanto para teste de hipóteses. Foram identificadas sete características de condutas que, conjugadas, caracterizam a ilicitude concorrencial, a saber: (I) como pressuposto o poder de mercado do agente; (II) produção de efeitos líquidos negativos analisados à luz da regra da razão; (III) intenção do agente em criar dificuldade à constituição, ao funcionamento ou ao desenvolvimento de concorrentes; (IV) inexistência de poder de barganha bilateral; (V) exigência de exclusividade; (VI) existência de mecanismos de coerção entre os agentes; e (VII) discriminação injustificada de agentes. Doutrina e jurisprudência foram uníssonas ao asseverar que as condutas anticompetitivas unilaterais e verticais não são ilícitas per se, todavia devem ser analisadas à luz da regra da razão a fim de sopesar efeitos líquidos ao bem-estar dos consumidores. A pesquisa inovou ao propor classificação das características das condutas anticompetitivas como pressuposto, central e satélites. Presentes tais classes conjuntamente, há fortes indícios de conduta anticompetitiva ilícita.

\section{Palavras-chave}

Direito antitruste; direito concorrencial; condutas anticompetitivas; obstrução à livre concorrência; abuso de posição dominante; condutas uniformes; cláusulas de raio; regra da razão; práticas discriminatórias e fechamento de mercado. 


\begin{abstract}
Canalini, Alexandre de Almeida; Cristofaro, Pedro Paulo Salles. Unilateral and Vertical Conducts and the Brazilian Antitrust

Law. Rio de Janeiro, 2018. 148p. Monography - Department of Law, Pontifícia Universidade Católica do Rio de Janeiro.
\end{abstract}

Unilateral and vertical conducts have more frequently been an object of concern and debate as regards Antitrust law overseas. In Brazil the competition authority has devoted most of its time to the analysis of horizontal agreements. Thus, the aim of this study is to identify the characteristics of unilateral and vertical conducts considered illicit in the light of the Brazilian Antitrust law. A review of the literature was carried out, as well as of cases sentenced by CADE (the Brazilian Administrative Council for Economic Defense) and of case studies. Statistical procedures were applied both for frequency analysis and for hypothesis test. Those identified seven characteristics in conducts which, when combined, characterize unlawful competition, to wit: (I) the agent's market power as a compulsory legal prerequisite; (II) negative net effects in the light of the rule of reason; (III) the agent's intention in creating difficulties to the constitution, operation or development of competitors; (IV) nonexistence of bilateral bargaining power; (V) exclusivity requirement clauses; (VI) the existence of coercion mechanisms between agents; and (VII) unjustified discrimination against agents. The doctrine and jurisprudence were in unison in asserting that unilateral and vertical anti-competitive practices are not illicit per se, however they must be analyzed in the light of the rule of reason in order to weigh net effects to consumer welfare. The research innovated by propounding to classify the characteristics of the anticompetitive practices as compulsory legal prerequisite, central and satellite. When combined, there is strong evidence of illicit anticompetitive practices

\title{
Keywords
}

Antitrust law; competition law; unilateral and vertical conducts; obstruction to free competition; abuse of dominant position; uniform conduct; radius clause; rule of reason; discriminatory practices; market closure. 
Sumário

1. O Problema

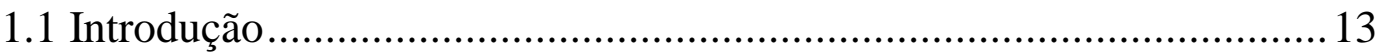

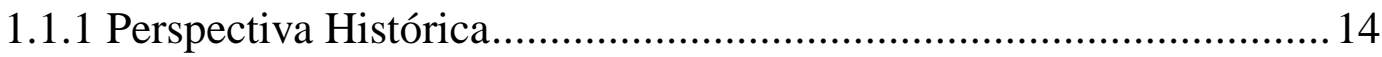

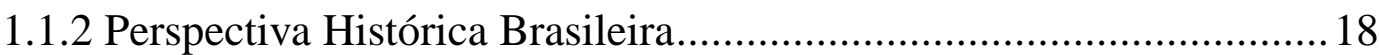

1.1.3 A Lógica do Sistema de Proteção Concorrencial ...............................21

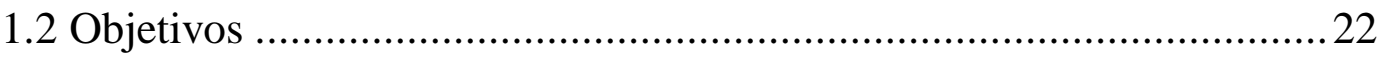

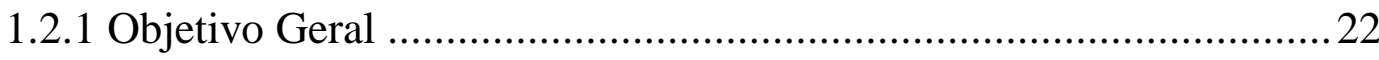

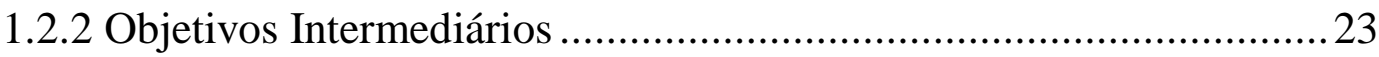

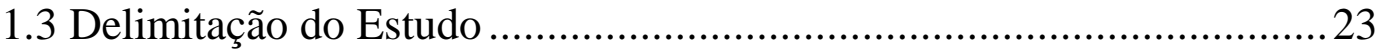

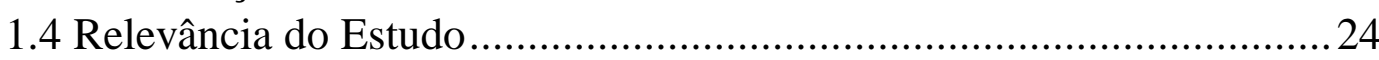

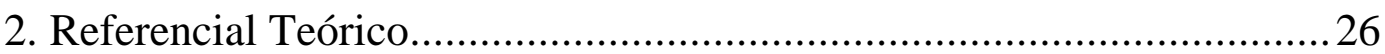

2.1 Aspectos Gerais da Repressão de Condutas Anticompetitivas .............22

2.1.1 As Condutas Anticompetitivas Horizontais e Verticais .....................27

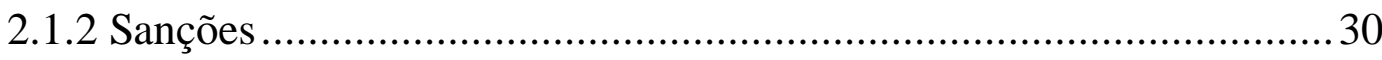

2.2 Condutas Coordenadas Horizontais ........................................................ 32

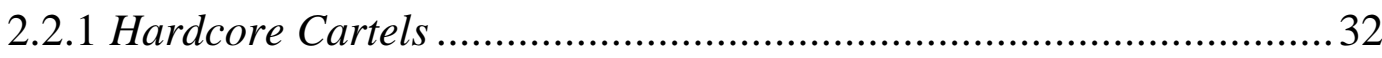

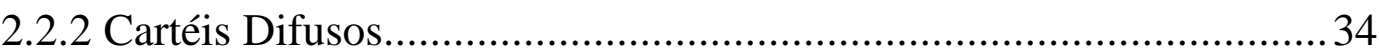

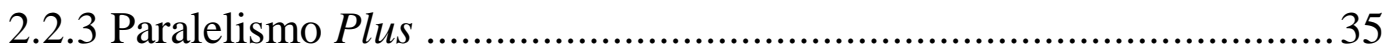

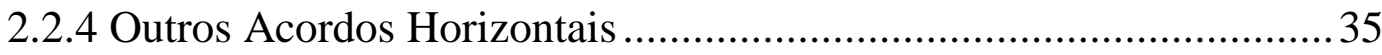

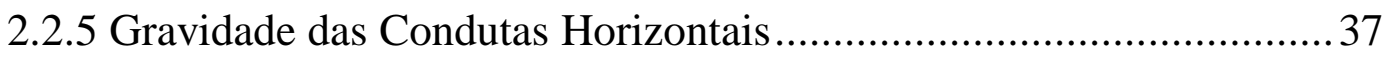

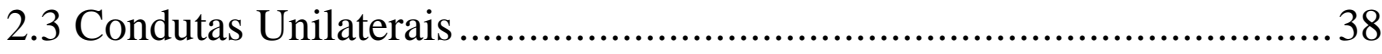

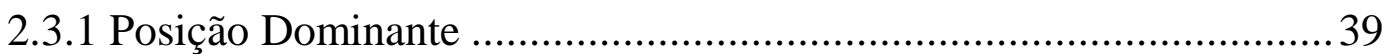

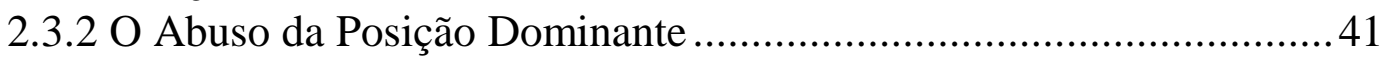

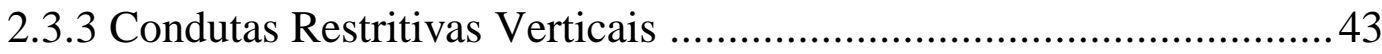

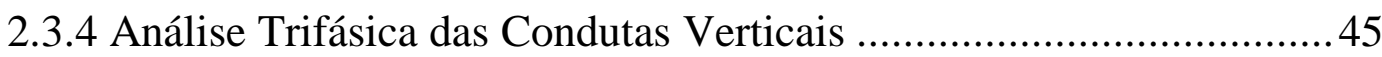

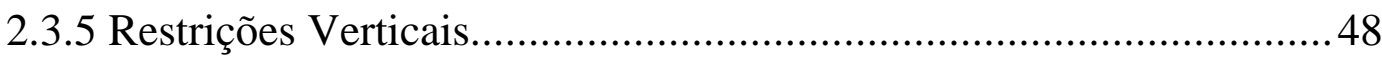

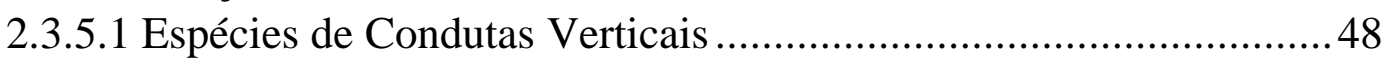

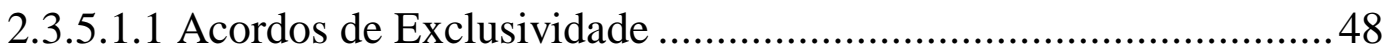

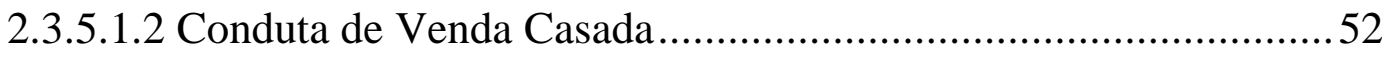

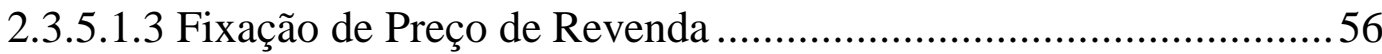

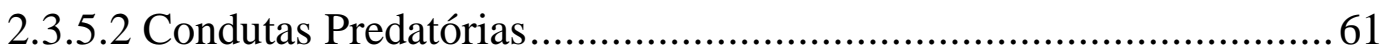

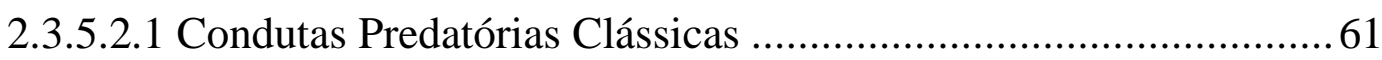

2.3.5.2.2 Novas Teorias de Predação............................................................. 70

2.3.5.3 Diversas Práticas de Abuso de Posição Dominante ......................... 71

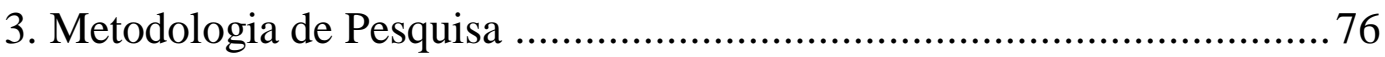

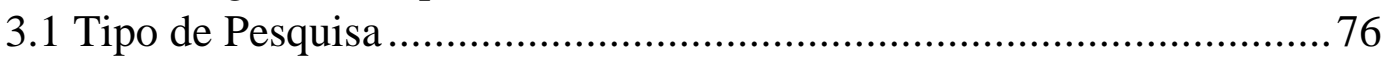

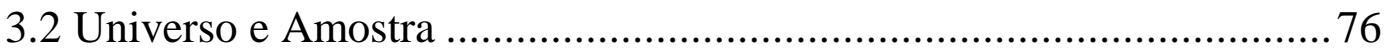

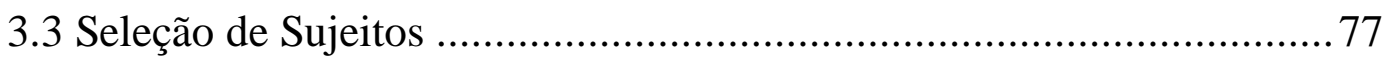

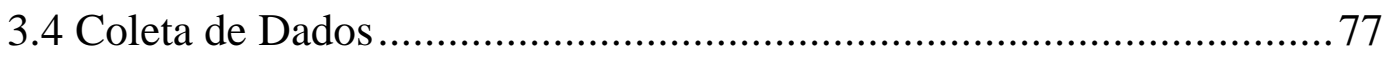




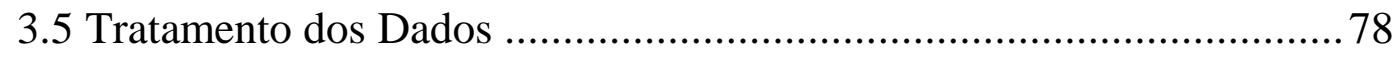

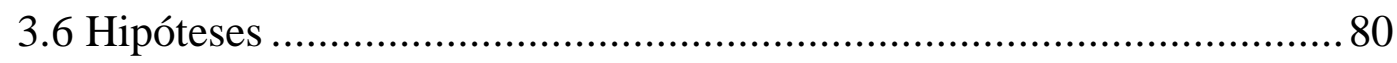

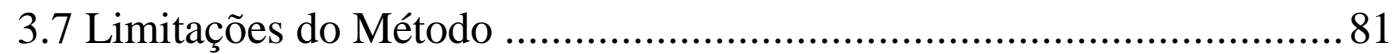

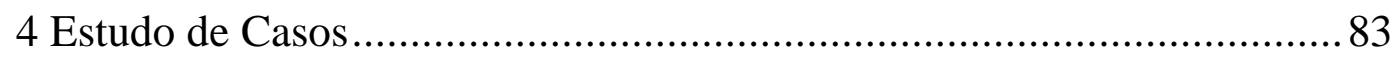

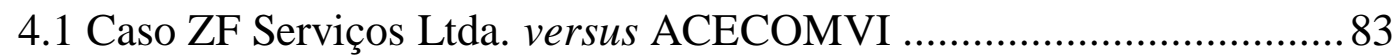

4.2 Caso Cade Ex Officio versus Unimed Missões ......................................89

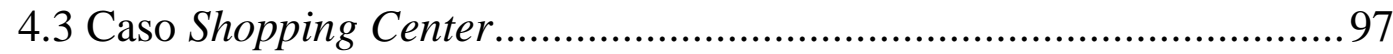

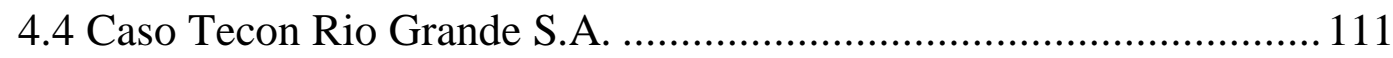

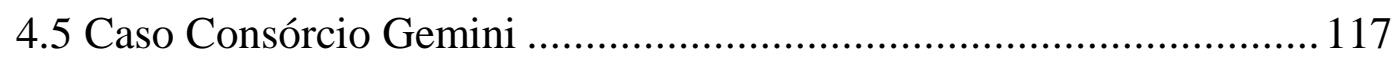

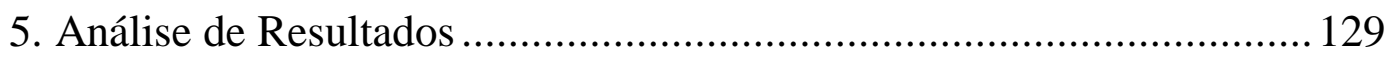

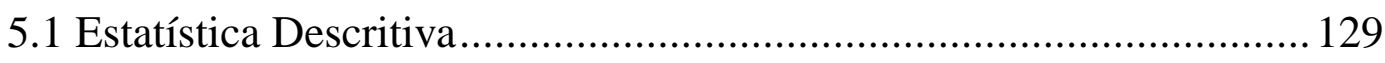

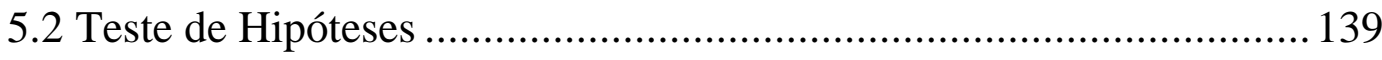

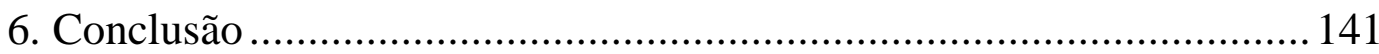

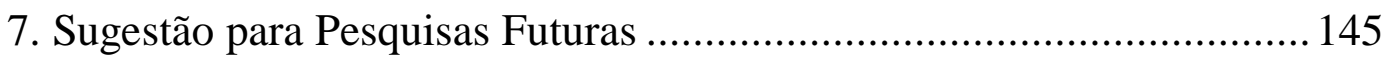




\section{Lista de Tabelas}

Tabela 1 - Condutas unilaterais e verticais recentes julgadas pelo CADE.. 77

Tabela 2 - Participação de mercado da UNIMED nos municípios ..............93

Tabela 3 - Resultado do teste estatístico.................................................. 131 


\section{Lista de Quadros}

Quadro 1 - Shopping centers membros da ACECOMVI .......................83

Quadro 2 - Shopping centers membros da ACECOMVI após desfiliações 84

Quadro 3 - Características da conduta da ACECOMVI........................ 129

Quadro 4 - Características da conduta da UNIMED Missões ................. 130

Quadro 5 - Características da conduta dos shopping centers................... 130

Quadro 6 - Características da conduta da TECON Rio Grande............... 130

Quadro 7 - Características da conduta no Consórcio Gemini.................. 131 


\section{Lista de Figuras}

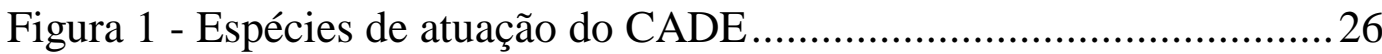

Figura 2 - Modalidades de avaliação de condutas horizontais .....................38

Figura 3 - Método de avaliação das condutas verticais ................................45

Figura 4 - Análise trifásica de condutas verticais .......................................46

Figura 5 - Fluxo da análise dos acordos de exclusividade ..........................50

Figura 6 - Fluxo da análise das práticas de venda casada ..........................53

Figura 7 - Fluxo da análise de prática de preço predatório ...........................63

Figura 8 - Faixas de análise de prática de preço predatório .........................70

Figura 9 - Fórmula utilizada no teste de hipótese Chi-Quadrado $\left(\mathrm{X}^{2}\right) \ldots \ldots . .80$

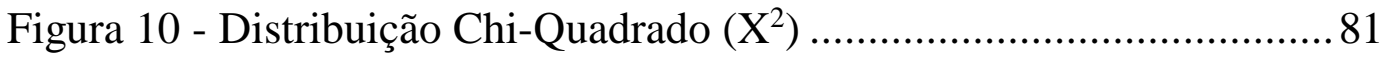

Figura 11 - Espécies de receitas dos shopping centers...............................98

Figura 12 - Área de Porto Alegre abrangida por cláusulas de raio ............102

Figura 13 - Saída do gás do duto de alta pressão para distribuição local.. 118

Figura 14 - Estrutura do Consórcio Gemini............................................. 120

Figura 15 - Classificação das características das condutas verticais.......... 144 


\section{Lista de Siglas e Abreviaturas}

ABL - Área bruta locável

ABRASCE - Associação Brasileira de Shopping Centers

ACECOMVI - Associação de Centros Comerciais Atacadistas de Santa

Catarina

ANS - Agência Nacional de Saúde Suplementar

CADE - Conselho Administrativo de Defesa Econômica

CDC - Código de Defesa do Consumidor

CDL - Companhia Distribuidora Local

CIF - Cost, Insurance and Freight

CIPE - Conselho Interministerial de Preços

Comgás - Companhia de Gás de São Paulo

CRFB - Constituição da República Federativa do Brasil

DEE - Departamento de Estudos Econômicos do CADE

DTA - Declaração de Trânsito Aduaneiro

EADI - Estações Aduaneiras Interiores

EUA - Estados Unidos da América

ERESP - Embargos de Divergência em Recurso Especial

GNC - Gás Natural Comprimido

GNL - Gás Natural Liquefeito

GLP - Gás Liquefeito de Petróleo

GNV - Gás Natural Veicular

IDH - Índice de Desenvolvimento Humano

IGP-M - Índice Geral de Preços do Mercado

INPI - Instituto Nacional da Propriedade Industrial

MPF - Ministério Público Federal

NPP - Nova Política de Preços da Petrobras

P\&D - Pesquisa e Desenvolvimento

Petrobras - Petróleo Brasileiro S.A.

ProCADE - Procuradoria Federal Especializada junto ao CADE

SEAE - Secretaria de Acompanhamento Econômico do Ministério da

Fazenda

SG - Superintendência Geral do CADE

STJ - Superior Tribunal de Justiça

STF - Supremo Tribunal Federal

SUNAB - Superintendência Nacional do Abastecimento

THC - Terminal Handling Charge

TRF - Tribunal Regional Federal 


\section{O Problema}

\subsection{Introdução}

A Constituição da República Federativa do Brasil (CRFB) de 1988 consagrou no inciso XXII do artigo 5 e no inciso II do artigo 170 o direito de propriedade dentre os Direitos Fundamentais. A Carta de 1988, ao tratar os Princípios Gerais da Atividade Econômica, traz no inciso IV do artigo 170 a livre concorrência.

A livre-iniciativa foi consagrada como princípio fundamental da República Federativa do Brasil. O inciso IV do artigo 1 da Carta Magna dispõe sobre os valores sociais do trabalho e a livre-iniciativa como valor fundamental com a mesma importância que outros valores como, verbi gratia, a dignidade da pessoa humana.

O artigo 170 da CRFB estabelece os princípios gerais que conformam a ordem econômica. A livre concorrência, prevista no inciso IV, fundamenta a ordem econômica.

O princípio da livre concorrência deve ser entendido como um princípio instrumental para se atingir o bem comum e o interesse da coletividade.

É importante destacar os referidos artigos a fim de demostrar inequívoca escolha do constituinte por um sistema de economia de mercado. A livre-iniciativa e a liberdade dos agentes são valores consagrados na Constituição da República Federativa do Brasil de 1988. Destarte, as limitações à livre-iniciativa e à livre concorrência devem ser tratadas como exceção.

As restrições por meio de regulações são justificáveis quando há abuso de poder econômico e uso do poder econômico para evitar a concorrência e para praticar atos ilícitos que prejudiquem a economia e o consumidor. Justificam-se também nos mercados regulados como, verbi gratia, os 
monopólios naturais. É o caso, por exemplo, do mercado de geração e transmissão de energia elétrica.

Regulação e concorrência coexistem de forma harmônica no mercado. É nesse contexto que o parágrafo quarto do artigo 173 da CRFB traz à baila a previsão para repressão do abuso do poder econômico utilizado a fim de dominar mercado e eliminar a concorrência.

\subsubsection{Perspectiva Histórica}

A concepção do Estado Liberal utiliza como fundamento o paradigma de que agentes econômicos, ao buscarem individualmente auferir lucros, realizariam trocas da melhor forma possível e como consequência trariam benefícios para a sociedade.

Não obstante a premissa utilizada na concepção do Estado Liberal, a história demonstrou que, nem sempre, a busca pela eficiência e o lucro individual traria necessariamente o bem-estar coletivo.

No século XIX, a liberdade dos agentes econômicos era uma das principais características da economia norte-americana. Havia constante disputa entre agentes a fim de dominar mercados. A prática, em tese, seria capaz de gerar riqueza e eficiência.

Não obstante os fundamentos do liberalismo, as distorções logo apareceram. A concepção liberal não se sobrepôs à concepção econômica presente na lei da oferta e demanda. Produtos mais escassos mostram-se mais onerosos aos consumidores, enquanto produtos mais ofertados no mercado mostram-se menos onerosos.

Em um mercado em que há concorrência perfeita os preços tendem ao equilíbrio. As curvas da oferta e da demanda encontram-se naturalmente formando o preço de equilíbrio. 
Situação diversa ocorre quando inexiste concorrência perfeita como, verbi gratia, no mercado monopolista. Se somente um agente atua em determinado mercado, os preços são determinados pelo encontro das curvas da oferta e da demanda, distinto em relação ao mercado em que há concorrência perfeita.

Nesta condição de mercado, os consumidores pagam preços mais elevados em função de somente um agente ser responsável pela produção do produto. A ausência de competição permite aumento no lucro do agente com a prática de preço distinto ao que seria possível em um mercado competitivo. Uma decisão do monopolista de reduzir o número de produtos ofertados em um mercado com demanda constante é capaz de elevar o preço e o lucro do agente.

É nesse contexto que os estados começaram a notar a necessidade de um conjunto de normas jurídicas capazes de tratar a atuação dos agentes econômicos, especialmente os que detêm mais poder econômico e poder de mercado. Surge então o Direito da Concorrência.

O estudo histórico de condutas anticoncorrenciais tem um de seus primeiros registros relatados por Aristóteles, na Grécia ${ }^{1}$. O filósofo e matemático Tales de Mileto previu abundante safra de azeitonas. Ciente de que eram necessários lagares para processar as azeitonas, decidiu alugar todos os lagares nas cidades de Chio e Mileto.

$\mathrm{Na}$ época da colheita detinha monopólio dos lagares na região. Com isso cobrou preço acima do que se pagaria para processar as azeitonas em condições normais. Aristóteles relata que Tales de Mileto pagou valor diminuto pela locação dos lagares, visto não haver muitas pessoas interessadas na locação. Uma referência inequívoca à lei da oferta e procura na formação de preço.

\footnotetext{
${ }^{1}$ FORGIONI, Paula. Os Fundamentos do Antitruste. 7.ed. rev. e atual. Editora Revista dos Tribunais. 2014. Capítulo 1, Disciplina do comportamento dos agentes econômicos nos mercados e concorrência: três momentos diversos, p. 38.
} 
A doutrina liberal defendia que o mercado livre levaria a uma situação de eficiência. Agentes livres no mercado buscariam processos e técnicas eficientes a fim de produzir mais com custos reduzidos e assim ofertar produtos no mercado a preços menores.

Da aplicação dos princípios da doutrina liberal surgiram múltiplos efeitos. Alguns, desejáveis; outros, contraditórios e indesejáveis. A preocupação tornou-se combater os efeitos indesejáveis surgidos da aplicação da doutrina liberal.

O primeiro efeito indesejado foi a conduta anticompetitiva dos agentes econômicos. Se a doutrina liberal partia da premissa de que os agentes competiriam para buscar eficiência e redução nos preços com benefício para a sociedade, o estudo histórico mostrou que os agentes passaram a estabelecer acordos para evitar a competição e frustrar a concorrência promovendo ineficiências.

Ausente um conjunto de normas capazes de regular o mercado e tendo como regra a liberdade dos agentes, acordos que visavam a reduzir a competição no mercado começaram a ocorrer, criando situações de abuso e ineficiência de mercado. Assim, formaram-se cartéis entre agentes econômicos.

Os cartéis evoluíram por meio de acordos entre os agentes. Inicialmente os acordos não eram considerados ilícitos, todavia também não permitiam às partes buscar tutela jurisdicional para a execução específica dos acordos. Daí começaram a surgir os trusts. Estes passaram a institucionalizar os cartéis norte-americanos.

O segundo efeito indesejado surgiu quando agentes econômicos com elevado poder de mercado usaram o poder para impedir, reduzir ou eliminar a concorrência. A conquista de poder de mercado e poder econômico é lícita e desejável para os agentes econômicos. Não obstante, o uso do poder conquistado de forma ilícita passou a ser objeto de preocupação dos estados. 
O poder econômico de agentes foi usado para criar barreiras para outros competidores. Tal prática limitava ou eliminava a concorrência trazendo ineficiências para os mercados e consumidores. Ausente qualquer regra de direito, o estado não atuava para coibir tais abusos.

A anomia aos poucos tornou o mercado cada vez mais ineficiente, contrário ao previsto pelos ideais liberais. A institucionalização dos cartéis com a criação de trusts foi um passo importante. A uma, solucionou os problemas de traição entre membros, uma vez que não era possível usar a jurisdição para a execução do acordo. A duas, a existência de um acordo formal e regulado entre as partes passou a ser objeto de interesse do estado a fim de avaliar se os termos pactuados seriam lesivos ao ambiente de concorrência.

Dentre os trusts mais conhecidos na época, o Standard Oil Trust. Foi o momento em que o estado americano notou que seria necessário agir a fim de garantir a existência da concorrência. Daí surgiram as campanhas e legislações antitruste.

A legislação norte-americana evoluiu para enfrentar as ineficiências observadas no mercado. A resposta do governo foi o Sherman Act em 1890, um dos primeiros atos de um governo a fim de reduzir as distorções concorrenciais observadas no mercado.

O Sherman Act pode ser resumido em dois pilares. O primeiro considerou ilícito qualquer acordo entre direitos econômicos que limite a competição entre agentes nos estados americanos. Criou multas e prisão para os agentes que deixassem de cumprir as regras. $\mathrm{O}$ segundo tratou as condutas unilaterais ou tentativas de monopolização. Novamente, tratou os atos que têm por objetivo levar à monopolização do mercado, aplicando penalidades e multas.

Não obstante ter sido publicado em 1890, o Sherman Act permanece vigente com poucas alterações; é aplicado ao direito norte-americano no 
direito antitruste. Algumas legislações surgiram ulteriormente a fim de complementar e enfrentar novos problemas surgidos com a evolução da economia.

Os problemas não se limitaram ao mercado norte-americano. Outros países observaram problemas no direito concorrencial, com isso muitos usaram o Sherman Act como referência para legislações voltadas à defesa da concorrência. A Comunidade Europeia fez presente nos artigos 85 e 86 do Tratado de Roma a garantia de existência de concorrência entre agentes econômicos.

\subsubsection{Perspectiva Histórica Brasileira}

É importante estudar o direito concorrencial no Brasil à luz da história e da política brasileira.

A livre concorrência é um princípio trazido pela Constituição da República Federativa do Brasil de 1988. O papel do Estado brasileiro e a definição de competição estão presentes desde a Constituição de 1934. Não obstante, o país demorou a construir um modelo jurídico de direito concorrencial em função do contexto político e de um mercado fechado.

Por vezes, o país incentivou o monopólio de alguns setores econômicos. Algumas sociedades tinham monopólio de exploração de áreas, monopólio de comércios, monopólio de segmentos econômicos, dentre outros. Não raro, o Governo organizou e elegeu os monopolistas.

Nos anos trinta houve um decreto considerando ilícitos determinados acordos entre agentes, todavia não foi aplicado. Em 1945, a Lei Malaia (Agamenon) tratou de Direito da Concorrência, entretanto com maior preocupação da proteção do mercado nacional contra a concorrência estrangeria. Com a saída de Getúlio Vargas da presidência, as leis perderam eficácia. 
Em 1962 surgiu a Lei 4.137 que tratava do Direito da Concorrência. Considerou ilícitas práticas da concorrência e criou o CADE (Conselho Administrativo de Defesa Econômica). O CADE nasceu como um órgão integrante da administração direta, era um conselho que integrava o Ministério da Justiça.

A Lei 4.137 definia punições e tipificava o cartel, contudo foi pouco aplicada no Brasil, uma vez que o país não tinha cultura concorrencial. Nos anos sessenta e setenta, o Estado atuava e também controlava os agentes privados; foram momentos da história com controle de preço, congelamentos e medidas impostas pelo governo.

Além da SUNAB, o CIPE fixava preços na economia. Eram cartéis organizados pelo Estado brasileiro, escolhia-se o produto líder do mercado, portanto a lei não era aplicada.

O cenário econômico do país era ainda mais desfavorável com a inflação, porquanto se perdia a referência de preço. O CADE teve atuação tímida durante tal período.

O contexto econômico do país mudou em 1994 com o Plano Real. Elaborado por um grupo de professores da PUC-Rio, promoveu estabilidade e previsibilidade na economia. O programa de privatizações, além de ter trazido alterações na composição dos mercados, aumentou a concorrência, tornando necessárias alterações nas legislações. No novo contexto surgido no Brasil foi necessário alterar o Direito da Concorrência; destarte, surgiu a Lei 8.884 de 1994.

A Lei 8.884 de 1994 alterou o Direito da Concorrência em vários pontos. Primo, o CADE deixou de ser uma entidade da administração direta e passou a organizar-se como autarquia de regime especial. Os conselheiros passaram a ser escolhidos por meio de indicação do Presidente da República com ulterior aprovação pelo Senado Federal. Secundo, as decisões do CADE passaram a ser finais no direito da concorrência. 
O CADE assumiu estrutura semelhante à das Agências Reguladoras, todavia sem produção de normas destinadas à regulação do mercado, porém passando a pautar o comportamento dos agentes econômicos.

A Lei 8.884 fez distinção relevante no Direito da Concorrência. De um lado, as condutas entendidas como práticas, atos e acordos entre agentes sobre direitos econômicos; quando necessário, aplicando penalidades. De outro, a Lei 8.884 tratou os atos de concentração, operações a princípio lícitas; todavia, em função da magnitude e concentração em um mercado, passaram a necessitar de aprovação do CADE.

As condutas podem ser definidas como práticas, atos e acordos entre agentes econômicos. A Lei 8.884 tratou as condutas e aplicou penalidades. Além das condutas, a lei tratou um segundo ponto, que são os atos de concentração. São operações em princípio lícitas, contudo em determinada dimensão causariam concentrações ao mercado, fazendo que esses atos tivessem que ser aprovados pelo CADE. Alguns atos de concentração passaram a ser submetidos ao CADE para aprovação. O direito da concorrência tornou-se realidade no Brasil.

A Lei 8.884 vigorou até o surgimento da Lei 12.529 de 2011, que passou a vigorar em 2012. A nova lei pretendeu ser um aperfeiçoamento da Lei 8.884. No cerne manteve os mesmos princípios e bases da Lei 8.884, racionalizando a atuação do Estado para concorrência.

É importante considerar as inovações trazidas pela Lei 12.529 de 2011. O CADE incorporou funções da Secretaria de Direito Econômico (Ministério da Justiça) e da Secretaria de Acompanhamento Econômico (no Ministério da Fazenda). Os atos de concentração que eram levados $a$ posteriori passaram a ter que ser submetidos ao CADE a priori.

Pode-se afirmar que houve deslocamento do objetivo do Direito da Concorrência. Subsistiu a manutenção do funcionamento do mercado de forma adequada. Mais que isso, houve consenso em que há um objetivo 
mediato ao atendimento do consumidor. Esperou-se que, por meio de um funcionamento adequado dos mercados, os consumidores teriam acesso à multiplicidade de produtos a um preço adequado. $\mathrm{O}$ sistema de defesa da concorrência tem como objetivo garantir aos consumidores preços adequados e alternativas que inexistiriam em um mercado imperfeito.

\subsubsection{A Lógica do Sistema de Proteção Concorrencial}

A proteção ao consumidor almejada na Lei 12.529 de 2011 como objetivo mediato do Direito da Concorrência não deve ser confundida com a proteção do consumidor existente no Código de Defesa do Consumidor (CDC).

O CDC protege o consumidor considerando a relação em que o consumidor é hipossuficiente; o Direito da Concorrência almeja levar produtos por preços os mais adequados possíveis e opções que inexistiriam em um sistema monopolizado.

A semelhança entre preço e custo, regra segundo a qual se produz o quanto se quiser até chegar ao preço de mercado, é aplicável para os mercados onde haja competição perfeita, pois nenhum competidor teria a possibilidade de alterar o preço do mercado.

O encontro das curvas de oferta e demanda forma o preço. Não obstante, há casos em que um agente sozinho consegue aumentar a oferta de forma relevante e levar a um preço de equilíbrio mais baixo ou, se reduz muito a quantidade, consegue elevar o preço de equilíbrio. É um funcionamento distinto do mercado perfeito.

Nos mercados perfeitos, os produtores são tomadores de preço, sabem que não podem alterar preço do mercado, portanto tomam o preço de mercado como dado externo e produzem para vender ao preço de mercado próximo ao custo. 
Tal mercado é hipotético e idealizado. Existe se há muitos produtores sem poder de mercado com produtos semelhantes sendo levados a milhares de consumidores que também não têm poder econômico.

Afastadas a existência de mercados absolutamente perfeitos e a de poucos monopólios, observam-se com mais frequência os mercados com características intermediárias. Agentes que não são monopolistas, todavia, exercem grande influência no mercado por meio de condutas independentes e indiferença em relação aos demais que atuam no mercado.

Neste contexto surgem prejuízos para os consumidores, pois passam a ter menos alternativas, preços mais elevados e alocação ineficiente dos recursos. A economia também é prejudicada ao ter mais recursos canalizados ao setor concentrado.

O busílis do Direito da Concorrência é a forma pela qual a posição dominante é conquistada e exercida. Posições dominantes conquistadas em conformidade com o sistema de mercado não são objeto do Direito da Concorrência, tampouco o é o uso do poder de mercado que não impeça a livre concorrência.

O Direito da Concorrência visa a proteger o mercado contra posições dominantes capazes de impedir acesso ao mercado, práticas de abusos de poder, limitação da concorrência e atos de concentração que tornem o mercado ineficiente.

\subsection{Objetivos}

\subsubsection{Objetivo Geral}

A pesquisa objetiva identificar as características das condutas anticompetitivas unilaterais e verticais ilícitas julgadas em 2016 e 2017 pela autoridade antitruste brasileira. Após identificar as condutas, objetiva-se 
compreender as principais características que as tornam ilícitas à luz do direito concorrencial brasileiro.

\subsubsection{Objetivos Intermediários}

Para fins deste trabalho, procurou-se inicialmente identificar e compreender as condutas anticompetitivas submetidas à análise da autoridade antitruste brasileira, bem como compreender o segmento de atuação das empresas representadas a fim de avaliar a conduta dos agentes.

A compreensão das particularidades de cada segmento econômico de atuação das empresas representadas em conjunto com as características das empresas analisadas foram etapas intermediárias relevantes a fim de identificar condutas prejudiciais ao ambiente concorrencial.

\subsection{Delimitação do Estudo}

Dentre as condutas consideradas ilícitas à luz do direito concorrencial brasileiro destacam-se duas espécies. (I) No que se refere ao número de agentes envolvidos, a conduta pode ser classificada como Acordos, quando há mais de um agente envolvido, ou Condutas Unilaterais, quando somente um agente pratica a conduta. (II) Quanto aos efeitos, a conduta pode ser classificada como vertical, quando seus efeitos afetam dois ou mais mercados relevantes, ou horizontal, quando afeta apenas um mercado relevante.

Em que pese a maior frequência de julgamentos de ilícitos concorrenciais da espécie Acordo Horizontal pela autoridade antitruste brasileira como, verbi gratia, prática de cartéis, o presente estudo limita-se a analisar julgados de condutas unilaterais e verticais.

Não obstante a existência de tais condutas em países como EUA e no continente europeu, a pesquisa limita-se a estudar as condutas unilaterais e 
verticais julgadas no Brasil, ainda que casos estrangeiros sejam aventados como mera comparação.

A pesquisa utiliza julgados recentes pela autoridade antitruste brasileira. Os casos analisados limitam-se aos julgados mais relevantes sobre o tema ocorridos nos anos de 2016 e 2017.

\subsection{Relevância do Estudo}

A CRFB de 1988 traz de forma expressa a livre-iniciativa no inciso IV do artigo 1 como princípio fundamental do Estado brasileiro. Dentre os princípios gerais da atividade econômica, o inciso IV do artigo 170 trata a livre concorrência.

A interpretação da Carta Magna mostra ser inequívoca a liberdade dos agentes para atuar no mercado. A busca pelo lucro e o ganho de eficiência naturalmente fazem que as empresas melhores ganhem poder de mercado e passem a deter maior participação de mercado.

Em que pese a naturalidade da conquista de mercado como consequência de práticas empresariais eficientes, o direito antitruste preocupa-se com abusos do poder de mercado ou com práticas ilícitas para conquista de mercado.

É neste contexto que o parágrafo quarto do artigo 173 da CRFB referese à repressão do abuso do poder econômico que vise à eliminação da concorrência e ao aumento arbitrário de lucros.

Destarte, o estudo mostra-se relevante e desafiador porque de um lado estão os valores da livre-iniciativa e da livre concorrência, de outro a preocupação do Estado com abusos de poder econômico que prejudiquem os concorrentes e os consumidores. Sopesar tais valores é tarefa de grande relevância. 
O bem-estar do consumidor também é um valor que identifica a relevância do estudo. Distinto do CDC, que se preocupa com a relação de hipossuficiência do consumidor, o direito antitruste mostra-se importante ao tratar as condutas dos que detêm poder de mercado e o usam a fim de limitar ou reduzir a concorrência em prejuízo do consumidor.

A estudo é relevante também sob o prisma econômico. Conquanto um ilícito concorrencial ocorra em determinado setor da economia, outro setor é indiretamente afetado, uma vez que há excesso de deslocamento de recursos para o setor em que há prática de preços artificiais.

$\mathrm{O}$ estudo mostra-se relevante ao limitar o poder dos agentes mais fortes quando identificada uma conduta ilícita sob a óptica concorrencial. A ação do órgão antitruste beneficia tanto os concorrentes do agente que pratica a conduta ilícita quanto os consumidores. A relevância do estudo é inequívoca pela proteção ao mercado e ao mesmo tempo o impedimento do Estado de imiscuir-se no mercado em detrimento da livre-iniciativa e livre concorrência.

Por fim, o estudo do tema é relevante visto que Acordos Verticais são práticas empresariais frequentes, que podem trazer benefícios tanto para os agentes quanto para os consumidores. Dessa forma, a falta de conhecimento quanto aos limites de validade de tais acordos gera insegurança jurídica para os envolvidos e possível prejuízo para os consumidores, que poderão não ser beneficiados por tais práticas quando lícitas. 


\section{Referencial Teórico}

O parágrafo quarto do artigo 173 da Constituição da República Federativa do Brasil dispõe sobre o tema concorrencial. Igualmente, o Título V da Lei 12.529/2011 trata as infrações da ordem econômica.

O CADE desempenha papel fundamental na defesa da concorrência. Atua em duas grandes frentes, a saber: (I) controle das operações que promovam concentração no mercado, bem como na (II) repressão de condutas consideradas anticompetitivas.

A expressão "condutas anticompetitivas" pode ser compreendida como gênero que abarca espécies distintas. Algumas características são comuns; são os aspectos gerais das condutas anticompetitivas. Dentre as duas grandes espécies podem ser identificados os Acordos (Condutas Coordenadas) e as Condutas Unilaterais.

Conquanto o escopo do presente trabalho seja analisar as condutas anticompetitivas unilaterais e verticais, passam-se em revista os aspectos gerais e os principais acordos horizontais antes de tratar as condutas unilaterais e verticais.

Figura 1 - Espécies de atuação do CADE

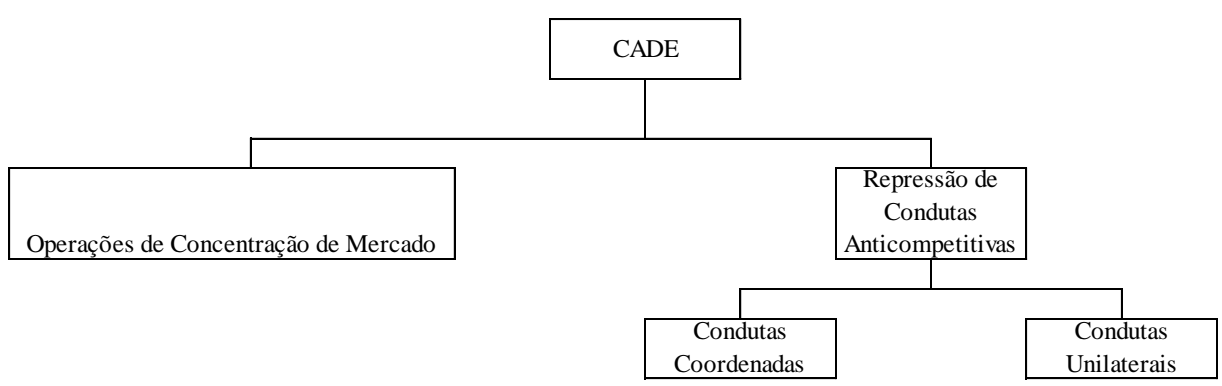

Fonte: elaboração do autor com base na leitura do site do CADE, 2018. 


\subsection{Aspectos Gerais da Repressão de Condutas Anticompetitivas}

\subsubsection{As Condutas Anticompetitivas Horizontais e Verticais}

As condutas horizontais envolvem sociedades empresariais que atuam no mesmo segmento de mercado como, verbi gratia, dois concorrentes diretos. Produzem efeitos em somente um mercado relevante.

As condutas verticais, por sua vez, envolvem sociedades empresariais que atuam em etapas distintas da cadeia de produção e distribuição. Neste caso, vê-se com grande frequência condutas anticompetitivas na relação entre fornecedores e distribuidores.

O estudo das condutas anticompetitivas à luz da Lei 12.529/2011 deve ser realizado por meio de interpretação conjunta do caput do artigo 36, incisos e parágrafo terceiro do diploma legal. O parágrafo terceiro traz hipóteses numerus apertus de condutas anticompetitivas.

Destarte, para que uma conduta presente no parágrafo terceiro do artigo 36 da Lei 12.529/2011 seja ilícita e sancionável é necessário que sejam atingidas as hipóteses previstas nos incisos do artigo 36.

É relevante buscar o entendimento da origem e da evolução histórica das leis concorrenciais estrangeiras a fim de compreender a lei nacional.

A evolução da legislação concorrencial norte-americana construiu a classificação das condutas anticompetitivas por meio da rule of reason. A regra da razão utiliza como premissa que as condutas potencialmente anticompetitivas podem trazer efeitos positivos e negativos para o mercado.

Segundo a doutrina americana, a conduta só pode ser considerada ilícita sob o prisma concorrencial se os efeitos concorrenciais negativos superarem os efeitos positivos. É a regra geral padrão utilizada pelas autoridades norte-americanas.

Não obstante, há, em caráter excepcional, casos em que as autoridades entendem que é dispensável sopesar os efeitos negativos e positivos de 
condutas anticompetitivas, uma vez que o objeto da conduta por si só é considerado ilícito. São as denominadas condutas ilícitas per se.

O entendimento da classificação das condutas anticompetitivas adotadas no mercado norte-americano não é mero exercício acadêmico, pois a espécie da conduta determina o padrão de prova nos processos anticoncorrenciais.

Se nas condutas sujeitas à regra da razão é necessário sopesar efeitos positivos e negativos ocorridos no mercado, nas condutas ilícitas em si mesmas (per se) a comprovação da conduta e da capacidade de gerar efeitos, malgrado não o gerem, será sancionada pelas autoridades.

$\mathrm{O}$ entendimento de tal classificação se mostra relevante para compreender a Lei antitruste pátria. Tanto a Lei 8.884/1994 quanto a atual Lei antitruste 12.529/2011, em conjunto com a Resolução n. 20 do CADE, consagraram a regra da infração concorrencial por efeito.

Lei 12.529/2011 Art. 36. Constituem infração da ordem econômica, independentemente de culpa, os atos sob qualquer forma manifestados, que tenham por objeto ou possam produzir os seguintes efeitos, ainda que não sejam alcançados: (Grifo meu).

I - limitar, falsear ou de qualquer forma prejudicar a livre concorrência ou a livreiniciativa;

II - dominar mercado relevante de bens ou serviços;

III - aumentar arbitrariamente os lucros; e

IV - exercer de forma abusiva posição dominante.

Resolução n. 20 CADE. Anexo I. Em diferentes graus, algumas podem também gerar benefícios em termos de bem-estar ao mercado ("eficiências econômicas"), recomendando a aplicação do "princípio da razoabilidade". Desse modo, é preciso ponderar tais efeitos vis-à-vis os potenciais impactos anticompetitivos da conduta. Portanto, uma prática restritiva somente poderá gerar eficiências líquidas caso as eficiências econômicas dela derivadas compensem seus efeitos anticompetitivos. (Grifo meu).

A leitura conjunta do artigo 36 da Lei 12.529/2012 e do Anexo I da Resolução n. 20 do CADE mostra que o Brasil adotou por padrão a avaliação dos efeitos líquidos de uma conduta para impor sanções. Nada obstante, a legislação nacional admite, em caráter excepcional, que uma conduta que tenha por objetivo produzir efeitos anticoncorrenciais seja considerada infração por objeto. 
O estudo das decisões do CADE mostra que os Acordos Horizontais conhecidos como cartéis clássicos (cartéis hardcore) são infrações consideradas ilícitas por objeto, dado que o cerne do acordo é a restrição à concorrência, isto é, o efeito vedado pela lei.

Nada obstante, mesmo no caso dos cartéis clássicos, o CADE tem avaliado a possibilidade de a conduta gerar efeitos. Entende-se como infração punível somente a ilicitude possível. A capacidade potencial de a formação do cartel gerar efeitos em conjunto com a prova da existência do cartel é suficiente para punição, dispensada qualquer análise de efeitos positivos e negativos.

É neste ponto que se observa a importância da distinção dos ilícitos por efeitos e por objeto. Nos ilícitos por objeto há presunção relativa (iuris tantum) dos efeitos da conduta. Isso significa que, uma vez que o CADE comprove a existência do cartel, caberá ao representado fazer a prova contrária a fim de afastar a presunção relativa. O representado é absolvido somente se demonstrar inexistência dos efeitos.

Nos casos em que há infração concorrencial por efeito, os requisitos para impor punição são mais rigorosos. Exige-se não somente a demonstração da existência da conduta como também seus efeitos líquidos. Nota-se que, nesse caso, há dupla exigência.

Nas infrações por objeto, ainda que as autoridades possam considerar a intenção dos agentes, a intenção não é um elemento essencial para a caracterização da infração. Nesses casos, mostram-se mais relevantes a natureza restritiva à concorrência intrínseca à conduta e a elevada probabilidade de prejuízo à concorrência.

Seguindo a jurisprudência europeia, as infrações por objeto devem ser consideradas objetivamente, isto é, independentemente da intenção do agente. Isso ocorre porque nesses casos o cerne do acordo anticompetitivo é 
a restrição à concorrência e a baixa probabilidade de efeitos positivos para o mercado.

\subsubsection{Sanções}

O Capítulo III da Lei 12.529, denominado Das Penas, define os critérios e sanções por infração da ordem econômica. Dentre as principais penas aplicáveis estão as multas, que podem atingir valores expressivos.

Art. 37. A prática de infração da ordem econômica sujeita os responsáveis às seguintes penas:

I - no caso de empresa, multa de $0,1 \%$ (um décimo por cento) a $20 \%$ (vinte por cento) do valor do faturamento bruto da empresa, grupo ou conglomerado obtido, no último exercício anterior à instauração do processo administrativo, no ramo de atividade empresarial em que ocorreu a infração, a qual nunca será inferior à vantagem auferida, quando for possível sua estimação [...].

Alguns autores criticam a manutenção da discricionariedade do CADE na aplicação da multa. Não obstante a Lei Concorrencial estabelecer um intervalo de $0,1 \%$ a $20 \%$ do faturamento bruto da sociedade empresarial no exercício anterior à instauração do processo administrativo no ramo em que ocorreu a infração, há um poder discricionário do CADE de estabelecer a reprimenda em um intervalo considerável.

Ademais, não há um critério objetivo para estabelecer o valor da multa. Inexistem parâmetros que possam ser usados para fixar a dosimetria da reprimenda. Ainda que o artigo 45 traga alguns parâmetros agravantes e atenuantes, salvo a reincidência, os demais critérios são subjetivos.

Para uns, uma grande insegurança; para outros, uma grande ferramenta. Alguns profissionais que atuam na área arguem que, fosse possível calcular o valor da multa de forma objetiva, seria fácil para a pessoa jurídica que quisesse agir de má-fé decidir pela infração sopesando a multa aplicada e as receitas que a conduta traria. Para outros, nem toda decisão de prática de ilicitude é tomada de forma tão racional. 
Quanto aos administradores da pessoa jurídica, a sanção obedece a critérios distintos. A uma, adota a responsabilidade subjetiva dos administradores, portanto deve ser comprovado o dolo na conduta. A duas, estabelece o intervalo entre um por cento e vinte por cento da multa aplicada à sociedade empresarial; neste ponto, uma inovação da Lei Concorrencial, uma vez que correlaciona a multa dos administradores à multa efetivamente aplicada à pessoa jurídica.

Art. 37. III - no caso de administrador, direta ou indiretamente responsável pela infração cometida, quando comprovada a sua culpa ou dolo, multa de $1 \%$ (um por cento) a $20 \%$ (vinte por cento) daquela aplicada à empresa, no caso previsto no inciso I do caput deste artigo, ou às pessoas jurídicas ou entidades, nos casos previstos no inciso II do caput deste artigo.

A nova Lei Concorrencial agravou as multas aplicadas às sociedades que não exercem atividade econômica. Organizações como sindicatos, associações profissionais e outras não econômicas, na falta de faturamento para servir de parâmetro de cálculo de multa, optou o legislador por definir valores nominais brutos entre cinquenta mil reais e dois bilhões de reais, notadamente elevado grau de discricionariedade dado ao CADE.

II - no caso das demais pessoas físicas ou jurídicas de direito público ou privado, bem como quaisquer associações de entidades ou pessoas constituídas de fato ou de direito, ainda que temporariamente, com ou sem personalidade jurídica, que não exerçam atividade empresarial, não sendo possível utilizar-se o critério do valor do faturamento bruto, a multa será entre $\mathrm{R} \$ 50.000,00$ (cinquenta mil reais) e $\mathrm{R} \$ 2.000 .000 .000,00$ (dois bilhões de reais) [...].

As sanções impostas aos infratores não se limitam às penas pecuniárias. Prevê o artigo 38 da Lei Concorrencial outras sanções como, verbi gratia, publicação da penalidade em jornais, proibição de contratar com a administração pública, inscrição do infrator no cadastro Nacional de Defesa do Consumidor, dentre outras penas.

Dentre as sanções previstas no artigo 38, a doutrina faz crítica especial ao inciso VII: "qualquer outro ato ou providência necessários para a eliminação dos efeitos nocivos à ordem econômica". 
Neste ponto existiria uma norma sancionatória aberta. O uso da palavra "qualquer" permitiria ao $\mathrm{CADE}$, ilimitadamente e com fundamento no referido inciso, proceder com qualquer ato necessário para eliminar os efeitos nocivos à ordem econômica. Daí surge a crítica ao possível poder irrestrito conferido ao CADE.

Conquanto o inciso VII do artigo 38 apresente a possibilidade de uma sanção aberta, deve-se observar que a aparente discricionariedade é temperada pelo princípio da proporcionalidade. Ademais, no caso do referido inciso, é necessário haver correlação entre a pena imposta e a eliminação dos efeitos anticompetitivos.

\subsection{Condutas Coordenadas Horizontais}

Em que pese ser o objetivo da presente pesquisa analisar as condutas unilaterais e verticais, é oportuno passar em breve revista os acordos ou condutas coordenadas horizontais.

As condutas coordenadas horizontais consistem em acordos realizados entre os que, em tese, deveriam concorrer. Dentre as condutas horizontais mais conhecidas estão os cartéis clássicos (hardcore cartel).

\subsubsection{Hardcore Cartels}

A legislação estrangeira concorrencial trata o cartel como prática ilícita à ordem econômica. Legislações como, verbi gratia, a norte-americana desde o início consideraram cartéis clássicos como ilícito per se. A legislação dos países europeus até a Segunda Guerra foi mais leniente com os cartéis, adotando a interpretação norte-americana com o passar dos anos.

A Lei Concorrencial pátria não menciona expressamente a palavra cartel, todavia há referência à prática. Consta no inciso I do $§ 3$ do artigo 36 da Lei 12.529/2011. 
$\S 3^{\circ}$. As seguintes condutas, além de outras, na medida em que configurem hipótese prevista no caput deste artigo e seus incisos, caracterizam infração da ordem econômica:

I - acordar, combinar, manipular ou ajustar com concorrente, sob qualquer forma:

a) os preços de bens ou serviços ofertados individualmente;

b) a produção ou a comercialização de uma quantidade restrita ou limitada de bens ou a prestação de um número, volume ou frequência restrita ou limitada de serviços;

c) a divisão de partes ou segmentos de um mercado atual ou potencial de bens ou serviços, mediante, dentre outros, a distribuição de clientes, fornecedores, regiões ou períodos;

d) preços, condições, vantagens ou abstenção em licitação pública [...].

A interpretação do texto normativo permite identificar que a legislação pátria considera cartel ajustes entre concorrentes que visem a dividir mercado ou a determinar oferta de bens e serviços ou, o caso mais conhecido, o acordo de preços.

O CADE adota a presunção relativa (iuris tantum) de efeitos negativos decorrentes da prática de cartel clássico. A autoridade administrativa tem o ônus de provar a existência do cartel clássico institucionalizado, pois os resultados nocivos à concorrência são presumidos.

A institucionalização do cartel é relevante especialmente em função da natural instabilidade dos cartéis. Daí a importância da existência de mecanismos de coação e monitoramento dos partícipes. A autoridade administrativa busca identificar se a conduta é permanente, com comportamentos padronizados, encontro periódico dos membros e unidade nas ações.

Além da institucionalização dos cartéis, o CADE avalia a estrutura do mercado investigado, uma vez que as condições de mercado podem facilitar condutas coordenadas. Tanto a Resolução n. 20 quanto a jurisprudência do CADE levam em consideração a estrutura do mercado. Os fatores são citados na referida Resolução. 
Resolução n. 20 Anexo I item 1. Alto grau de concentração do mercado, existência de barreiras à entrada de novos competidores, homogeneidade de produtos e de custos, e condições estáveis de custos e de demanda.

Destarte, a existência de um cartel será analisada à luz de dois requisitos, a saber: (I) a existência de acordo institucionalizado entre concorrentes a fim de restringir a competição; daí se presume a produção de efeitos anticompetitivos em função da (II) participação de mercado relevante dos membros do cartel. Satisfeitos tais requisitos, está comprovada a existência da ilicitude, dispensada qualquer análise de efeitos.

As provas requeridas pela autoridade antitruste estão diretamente relacionadas à espécie do ilícito. No caso em discussão, os cartéis clássicos, as provas dos efeitos são dispensadas; cabe ao CADE comprovar o acordo entre agentes com características institucionais a fim de restringir a concorrência.

\subsubsection{Cartéis Difusos}

Se os cartéis clássicos se caracterizam pelo elevado grau de institucionalidade por meio de mecanismos de monitoramento e sanção, os cartéis difusos são espécies de cartéis que não apresentam alto grau de institucionalização.

O cartel difuso caracteriza-se pela não institucionalidade e pela eventualidade. Não se evidencia a característica permanente presente nos cartéis clássicos. Apesar da menor gravidade do ilícito em função do menor potencial lesivo, o CADE também considera a formação de cartéis difusos uma conduta ilícita por objeto. 


\subsubsection{Paralelismo Plus}

A análise das decisões do CADE identifica casos em que houve sanção pela autoridade concorrencial sob acusação de prática de acordo horizontal, não obstante a ausência de provas de um acordo.

Tais decisões são fundamentadas pela Teoria do Paralelismo Plus. São casos em que se observou concomitantemente comportamento paralelo entre concorrentes e fortes indícios de acordo entre eles. São casos em que inexiste explicação racional para o comportamento paralelo entre concorrentes e há elementos que apontam para acordo entre os partícipes.

Muitas vezes baseados em provas indiretas, cada vez mais se buscam provas diretas para identificar o ilícito concorrencial. No caso da Teoria do Paralelismo Plus, isso se torna cada vez mais importante, uma vez que é natural em um mercado competitivo existir algum paralelismo entre concorrentes.

Quando um agente relevante no mercado decide alterar seu preço, naturalmente a concorrência tende a acompanhá-lo em tal decisão, especialmente em casos de elevações que possibilitam que o setor recupere margens.

Sancionar tais condutas, sem maiores evidências de ilícito concorrencial, pode gerar indesejável comunicação ambígua com o mercado. Ademais, poderia interferir na desejável concorrência que a própria autoridade administrativa deveria proteger.

\subsubsection{Outros Acordos Horizontais}

Em que pese os cartéis serem as práticas horizontais mais nocivas para concorrência, por vezes agentes realizam condutas horizontais que trazem efeitos anticompetitivos para o mercado, portanto são infrações da ordem econômica. 
Os acordos horizontais, diferentes dos cartéis, são capazes de produzir efeitos positivos e negativos na economia. É neste ponto que tais condutas se afastam dos cartéis, pois as demais condutas horizontais devem ser avaliadas sopesando aspectos positivos e negativos; portanto aplica-se a regra da análise por efeitos líquidos em vez da análise por objeto.

A Resolução n. 20 do CADE cita como exemplo iniciativas conjuntas temporárias para atingir eficiências e restrições a apenas uma parcela do mercado relevante.

Os acordos entre concorrentes são um bom exemplo. Não têm por fim restringir a concorrência, todavia podem reduzir a concorrência como efeito indireto do acordo. Visam diretamente ao ganho de eficiência e, como consequência, poderiam reduzir a competição.

Ainda que não tenham por fim restringir a concorrência, estão sujeitos ao artigo 36 da Lei 12.529/2011 e não necessitam de aprovação prévia da autoridade concorrencial. Neste contexto é necessário sopesar aspectos negativos e positivos de tais acordos, avaliando os efeitos líquidos para o mercado concorrencial. Afasta-se, assim, a presunção de efeitos aplicável aos cartéis.

Por fim, ainda como outras práticas de acordos horizontais estão as Práticas Facilitadoras. Frequentemente consistem no compartilhamento de informações entre sociedades empresariais que atuem no mesmo segmento.

Se por um lado tais compartilhamentos de informações podem gerar efeitos positivos para o mercado como, verbi gratia, ganhos de eficiência, por outro podem trazer efeitos anticompetitivos. Conhecendo informações dos concorrentes, é possível ajustar preços, alterar produção e restringir o ambiente competitivo.

Estão presentes na Lei Concorrencial no inciso II do $§ 3$ do artigo 36. Em regra, devem ser avaliadas à luz dos efeitos líquidos produzidos no 
mercado, sopesando efeitos positivos e negativos, exceto práticas de tabelamento de preços, consideradas pelas autoridades um ilícito por objeto.

\subsubsection{Gravidade das Condutas Horizontais}

A pesquisa das condutas horizontais identifica que há efeitos distintos provocados no mercado em função da espécie de conduta. Dentre as mais graves, sem dúvida os cartéis hardcore, pois o objeto é ilícito, há mecanismos institucionais para assegurar a eficácia da conduta dos partícipes e atuação permanente. São as condutas apenadas com maior severidade pela autoridade administrativa.

Em grau de gravidade logo abaixo estão os cartéis difusos. Em que pese terem por objeto práticas anticompetitivas, não têm mecanismos institucionais para dar eficácia ao seu objeto, tampouco apresentam caráter permanente.

Tanto os cartéis hardcore como os difusos são analisados pela autoridade concorrencial como infrações por objeto. Assim, não se busca verificar efeitos positivos e negativos, e sim a existência da prática. Uma vez constatada a prática, há presunção relativa (iuris tantum) dos efeitos nocivos no mercado; portanto caberá ao acusado desfazer a presunção por meio de prova contrária.

Em patamar distinto estão as condutas horizontais, que não visam a gerar efeitos anticompetitivos, todavia podem gerá-los. São condutas que são avaliadas pela autoridade concorrencial como ilícito não por objeto, e sim por efeitos. Deve-se aplicar a rule of reason a fim de avaliar a razoabilidade e os efeitos líquidos das condutas.

Dentre as espécies de condutas horizontais mais comuns sujeitas a avaliação por efeitos estão os acordos colaborativos entre sociedades empresariais concorrentes e as práticas facilitadoras. 
Figura 2 - Modalidades de avaliação de condutas horizontais

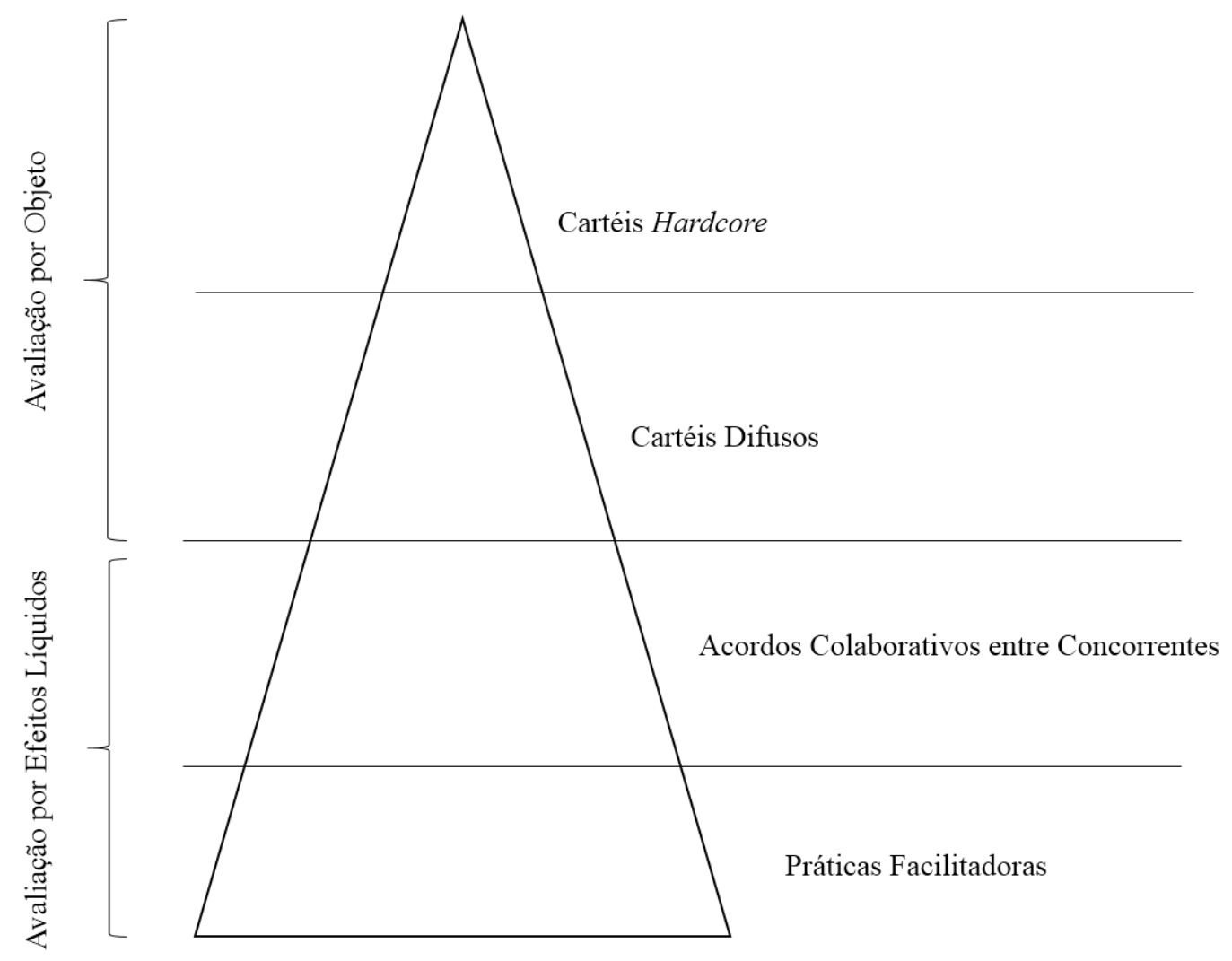

Fonte: elaboração do autor com base no livro Direito Concorrencial, 2016.

\subsection{Condutas Unilaterais}

Algumas sociedades empresariais são tão relevantes no segmento, que a conduta adotada, ainda que não pactuada com seus concorrentes, é capaz de gerar efeitos anticompetitivos no mercado.

Tais condutas são denominadas pela doutrina e pela jurisprudência de Condutas Unilaterais. Ainda que não tenham a intenção de reduzir a concorrência, são avaliadas e em alguns casos sancionadas pela autoridade concorrencial.

Previstas na legislação concorrencial pátria no artigo 36, incisos II e IV da Lei 12.529/2011, trazem especial preocupação à autoridade concorrencial quando impedem a entrada de novos competidores ou excluem concorrentes do mercado em função do poder de mercado do agente dominante. 
Art. 36. Constituem infração da ordem econômica, independentemente de culpa, os atos sob qualquer forma manifestados, que tenham por objeto ou possam produzir os seguintes efeitos, ainda que não sejam alcançados:

II - dominar mercado relevante de bens ou serviços;

IV - exercer de forma abusiva posição dominante.

Destarte, o ponto de partida do presente estudo é o entendimento do conceito de posição dominante, suas características e as práticas consideradas abusivas.

\subsubsection{Posição Dominante}

A fim de compreender o conceito de mercado competitivo e de posição dominante, utilizam-se como exemplo os mercados populares identificados nos grandes centros inspirados especialmente nas cidades do Rio de Janeiro e de São Paulo, a saber: o Mercado da Saara e o Mercado na Rua Vinte e Cinco de Março, respectivamente.

Nos mercados populares dos grandes centros há uma característica comum: os comerciantes são incapazes de impor seus preços ao mercado. Tal incapacidade decorre do elevado número de concorrentes em um mercado pulverizado.

Ao tentar impor um preço maior ao mercado, o comerciante frustrase, já que os clientes comprarão no estabelecimento ao lado por preço menor. Isso faz que os agentes sejam tomadores de preço, aceitem o preço como dado oriundo do mercado.

Em que pese a dificuldade de identificar na realidade fática mercados que tenham concorrência perfeita, os mercados populares dos grandes centros são os que mais se aproximam da concorrência perfeita.

Em tais mercados, o agente não pode atuar indiferente aos seus competidores, pois sua estratégia de atuação não é autônoma. É preciso 
avaliar a estratégia atento aos concorrentes, sob pena de perder participação no mercado e receitas.

Situação distinta dos mercados populares dos grandes centros ocorre quando se observa um mercado concentrado. Neste caso, poucos agentes atuam no mercado. Em função da concorrência diminuta, os agentes podem atuar com indiferença aos seus concorrentes.

Adotam condutas que são impostas ao mercado independentemente da concorrência. Tais condutas ocorrem quando um agente tem poder de mercado e atua de forma indiferente aos concorrentes.

A preocupação das autoridades concorrenciais está voltada aos agentes que têm poder de mercado e atuam exercendo práticas capazes de restringir a concorrência no mercado. É nesse contexto que há prejuízo aos consumidores.

A lei de defesa da concorrência pátria, no parágrafo segundo do artigo 36, traz algumas diretrizes sobre o conceito de posição dominante.

$\S 2^{\circ}$. Presume-se posição dominante sempre que uma empresa ou grupo de empresas for capaz de alterar unilateral ou coordenadamente as condições de mercado ou quando controlar $20 \%$ (vinte por cento) ou mais do mercado relevante, podendo este percentual ser alterado pelo CADE para setores específicos da economia.

A legislação pátria indica o conceito de posição dominante por meio de uma presunção relativa (iuris tantum). Para ter posição dominante, em tese, é necessário uma sociedade empresarial ou um grupo de sociedades empresariais ter no mínimo participação de vinte por cento do mercado relevante.

O market share por si só não é capaz de definir o agente como dominante, daí ser uma presunção relativa. É necessário analisar o mercado em que a sociedade empresarial atua, especialmente as barreiras de entrada. 
Em um mercado em que uma sociedade empresarial tenha mais que vinte por cento de market share e haja, verbi gratia, elevado dispêndio de capital para iniciar atividades por um potencial concorrente, nota-se a existência de barreiras de entrada.

São os casos mais preocupantes aos olhos da autoridade concorrencial, uma vez que se soma ao elevado market share a natural dificuldade de novos concorrentes, propiciando ao agente a possibilidade de impor de forma unilateral determinadas práticas ao mercado.

A caracterização da posição dominante de uma sociedade empresarial ou grupo de sociedades requer, além de elevada participação de mercado, o contexto do mercado que possibilite restringir a concorrência dos demais agentes ou dos concorrentes potenciais.

Assim, inequivocamente será considerada sociedade empresarial dominante aquela que tenha elevado market share e atue em um mercado propício ao exercício do seu poder, alterando de forma unilateral a competição.

\subsubsection{O Abuso da Posição Dominante}

Quando um pequeno empreendedor inicia a atividade empresarial, o plano de negócios elaborado visa a auferir lucros e a conquistar mercado. Não poderia ser diferente, pois as organizações naturalmente devem visar ao crescimento.

A partir de tal entendimento é possível concluir que a dominação de mercado não é ato ilícito; pelo contrário, é almejado pelo agente. Por vezes o governo atua por meio de mecanismos de fomento para que sociedades empresariais consigam crescer. 
A licitude da participação dominante, compreendida não somente pelo mercado como também pela legislação de defesa da concorrência pátria, está presente no parágrafo primeiro do artigo 36.

Art. 36. $\S 1^{\circ}$. A conquista de mercado resultante de processo natural fundado na maior eficiência de agente econômico em relação a seus competidores não caracteriza o ilícito previsto no inciso II do caput deste artigo.

O texto normativo é expresso quanto à licitude da conquista de mercado por agentes econômicos uma vez decorrente de eficiências do agente. A lei de defesa da concorrência deseja coibir a conquista de mercado que se utiliza de meios ilícitos, dentre eles o uso do poder dominante.

Em que pesem valores constitucionais como a livre concorrência e a livre-iniciativa, previstas na Carta Magna nos artigos 170, inciso IV, e 1, inciso IV, a lei de defesa da concorrência veda o abuso do direito. Não se permite que o agente dominante use seu poder de mercado para reduzir a competição.

Em um mercado competitivo, o preço é formado pela interseção das curvas da oferta e da demanda. Trata-se de fenômeno natural em um mercado competitivo. Nos mercados em que há um agente dominante, observa-se que o agente ou os agentes dominantes conseguem de forma unilateral deslocar as curvas da oferta e da demanda a fim de obter um preço de equilíbrio que os satisfaça em prejuízo do mercado.

Tal conduta pode ocorrer de diversas formas. O agente dominante pode elevar o preço de venda acima do equilíbrio natural; se os concorrentes não tiverem capacidade de produzir mais para conquistar o mercado do agente dominante, os consumidores serão prejudicados.

$\mathrm{O}$ agente dominante também pode reduzir o preço abaixo do custo a fim de gerar prejuízos para os demais concorrentes e futuramente se tornar monopolista. Quando exercer o monopólio, poderá recuperar as receitas perdidas com as vendas abaixo do custo por meio da elevação dos preços. 
As condutas podem também contemplar alteração da oferta de produtos. Se um agente dominante reduz a oferta em um mercado de demanda constante ou crescente, deslocará o preço de equilíbrio para patamar superior ao natural.

As condutas ilícitas não se restringem às políticas que envolvem preços. Podem ser utilizadas para restringir a competição dos concorrentes ou mesmo impedir que novos concorrentes acessem o mercado. Trata-se de prática comum denominada construção de barreiras.

As autoridades administrativas, não somente no Brasil, têm a árdua tarefa de distinguir quais condutas são ilícitas e prejudiciais ao desejável ambiente de competição no mercado das condutas que se caracterizam como estratégias organizacionais lícitas agressivas.

\subsubsection{Condutas Restritivas Verticais}

As condutas restritivas verticais, como já exposto, devem ser avaliadas sob a óptica dos efeitos líquidos. A autoridade concorrencial deve avaliar a conduta sopesando efeitos positivos e negativos decorrentes da conduta. Aplica-se a regra da razão em detrimento da análise do ilícito per se.

A fim de compreender uma espécie de conduta vertical e a avaliação da autoridade concorrencial, utiliza-se um exemplo. Por hipótese, uma sociedade empresarial Y que atua no segmento de mineração decide firmar contrato de fornecimento de minério de ferro com uma sociedade empresarial $\mathrm{Z}$ que atua no ramo de siderurgia.

Note que, se a siderúrgica $\mathrm{Z}$ adquirir parte significativa do minério de ferro da mineradora $\mathrm{Y}$, as demais siderúrgicas poderão ter a produção prejudicada em função da redução do insumo disponível no mercado ou da elevação do custo da matéria-prima. 
Num outro exemplo, pode-se imaginar uma sociedade empresarial A, grande produtora de bebidas, que firme contrato de exclusividade de distribuição de seus produtos com bares e restaurantes em uma cidade. Com tal prática, a produtora de bebidas dificulta significativamente a entrada de outros fornecedores concorrentes, reduzindo a competição.

Em comum entre os dois exemplos, os efeitos negativos da conduta para o ambiente competitivo. Os concorrentes terão mais dificuldade de acessar o mercado, outrossim, terão custos operacionais maiores.

Em que pesem os efeitos negativos, as duas condutas apresentam também aspectos positivos. No primeiro exemplo, o contrato de longo prazo traz estabilidade à relação entre as partes e possibilita a realização de mais investimentos, uma vez que a relação será duradoura. No segundo caso, a integração dos canais reduz custos com logística, aumenta a previsão de demanda e auxilia na previsão da quantidade a produzir.

Utilizando a metáfora da balança, a autoridade concorrencial avaliará os aspectos positivos e negativos da conduta vertical. Uma vez conhecidos os efeitos, irá sopesá-los. Se os aspectos positivos superarem os negativos, a autoridade concorrencial não poderá criar óbices quanto à prática adotada. 
Figura 3 - Método de avaliação das condutas verticais

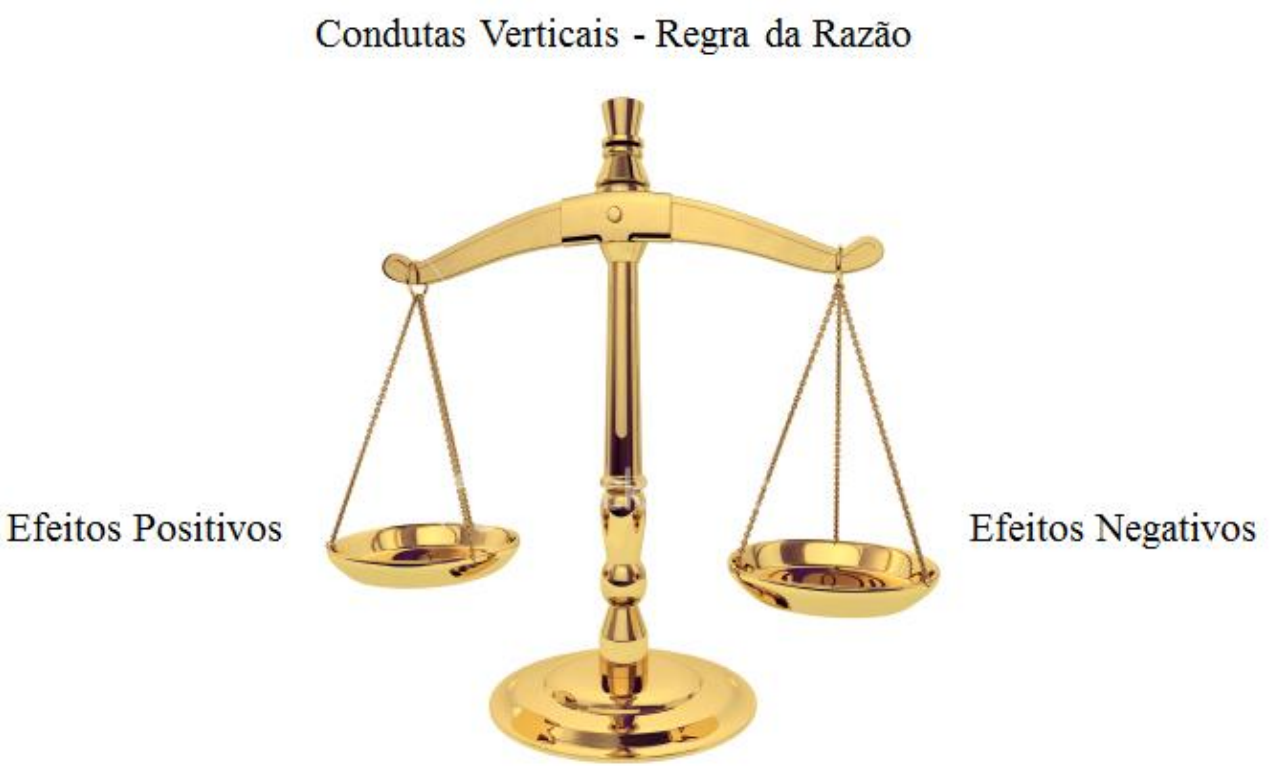

Fonte: elaboração do autor com base na doutrina de direito concorrencial.

\subsubsection{Análise Trifásica das Condutas Verticais}

As condutas verticais são capazes de concomitantemente produzir efeitos positivos e negativos ao ambiente concorrencial. Uma mesma espécie de conduta vertical pode ser lícita em um segmento e ilícita em outro.

Em decorrência das diversas consequências que uma conduta vertical pode propiciar, mister avaliar os efeitos líquidos da conduta a fim de perquirir a influência na concorrência. Caberá à autoridade concorrencial adotar critérios para avaliar as condutas verticais.

Neste sentido, a Resolução n. 20 do CADE ilumina a discussão sobre o tema. Primo, admitindo expressamente a existência de efeitos positivos e negativos. Secundo, conferindo especial importância à análise do risco de prejuízo à concorrência.

Assim, a análise das condutas verticais pela autoridade concorrencial segue um critério trifásico. A sanção ocorre quando a conduta é submetida às três fases do teste e apresenta resposta positiva. Caso em qualquer das fases 
a autoridade administrativa encontre resposta negativa, há elevada probabilidade de arquivamento. A figura ilustra o procedimento trifásico.

Figura 4 - Análise trifásica de condutas verticais

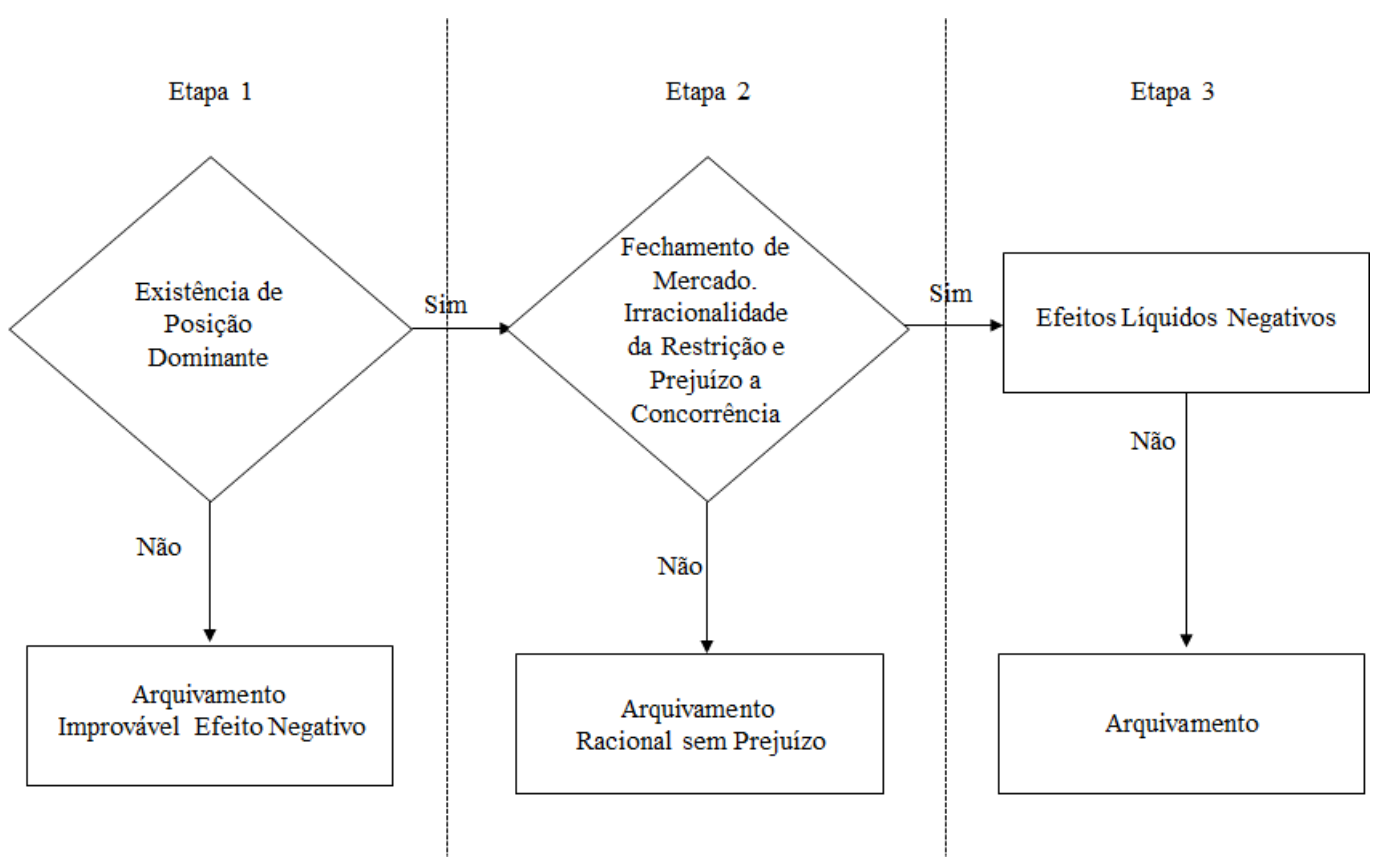

Fonte: elaboração do autor com base no livro Direito Concorrencial (pág. 142).

A autoridade antitruste inicia a análise buscando compreender se a investigada exerce posição dominante. Caso não seja possível identificar posição dominante, a conduta do agente não produzirá efeitos no âmbito concorrencial.

Toma-se como exemplo um agente que tenha participação de um por cento em um mercado com muitos concorrentes e sem barreiras de entrada. A conduta praticada pelo agente não será capaz de prejudicar a concorrência, portanto a investigação será arquivada.

Caso seja identificada a posição dominante do agente, busca-se, na segunda etapa, compreender se a conduta tem motivação racional, outrossim se seria capaz de gerar prejuízo ao ambiente concorrencial.

Nesta segunda etapa, a autoridade antitruste avaliará a motivação da conduta. É preciso existir motivação sob a óptica empresarial como, verbi 
gratia, redução de custos, ganho em produção, acesso a novos mercados, dentre outras motivações.

É natural e desejável que sociedades empresarias busquem expandir seus negócios. Neste sentido, condutas compreendidas como estratégias empresariais para expansão são lícitas, não obstante tragam alguma vantagem competitiva em relação aos concorrentes.

O que não se admite no âmbito da defesa da concorrência são condutas injustificáveis sob a óptica empresarial, condutas que visam a somente promover fechamento do mercado sem nenhuma outra motivação, lesando o consumidor ao restringir a concorrência.

Uma vez identificada a existência de posição dominante e irracionalidade da restrição ao mercado que acarrete prejuízo à concorrência, inicia-se a terceira etapa da análise da autoridade administrativa. É nesta etapa que serão investigados os efeitos líquidos.

É cediço que condutas unilaterais e verticais geram efeitos positivos e negativos para o ambiente concorrencial. Podem propiciar efeitos negativos como, verbi gratia, o fechamento do mercado, o aumento de custos para alguns agentes, dentre outros prejuízos.

Nada obstante, os consumidores podem ser beneficiados pelos efeitos da conduta. Cita-se como exemplo a redução do custo de produtos em função do ganho em eficiência, o acesso a novos produtos que antes da conduta eram inacessíveis, dentre outros efeitos positivos.

É com fundamento no estudo dos efeitos positivos e negativos que a autoridade administrativa avaliará se a conduta é um ilícito concorrencial. Ainda que nas etapas precedentes a conduta tenha as características de ilícito concorrencial, se na terceira etapa os efeitos líquidos forem positivos, a conduta não será sancionada. 


\subsubsection{Restrições Verticais}

\subsubsection{Espécies de Condutas Verticais}

\subsection{Acordos de Exclusividade}

Dentre as condutas verticais mais frequentes estão os acordos de exclusividade. Consiste em conduta segundo a qual um fornecedor pactua com um distribuidor a exclusividade na oferta de seus produtos ou um agente pactua com um fornecedor exclusividade para a aquisição de seus produtos.

A prática propicia eficiências para as partes. Ao pactuar exclusividade com distribuidores, o fornecedor passa a ter demanda constante por seus produtos. Ganha previsibilidade quanto à sua demanda, permitindo melhor planejamento de sua produção. São as denominadas ancillary restraints.

A realização de investimentos maiores e com mais segurança é uma eficiência dos acordos de exclusividade. Alguns fornecedores entendem que investimentos como, verbi gratia, treinamento de equipe de vendas sejam relevantes para a distribuição dos seus produtos.

Nada obstante, muitas vezes optam por não investir, uma vez que um vendedor não exclusivo pode usar o conhecimento adquirido no treinamento para vender um produto concorrente. Nesses casos, diz-se que o concorrente pegou uma carona (free riding) no treinamento promovido pelo seu rival. Nota-se aqui a importância da exclusividade.

Pode-se imaginar como exemplo um fabricante de carrocerias de caminhões marca $\mathrm{Z}$ que distribua seus produtos por meio de revendedores divididos regionalmente pelos estados federados. Com o intuito de melhorar a capacitação dos distribuidores, decide treiná-los; todavia, como não são exclusivos, poderão usar o conhecimento adquirido para vender o produto concorrente da marca Y. 
Busca-se compreender se as práticas de exclusividade apresentam justificativas racionais sob o prisma empresarial ou se têm por finalidade a restrição ao ambiente concorrencial (naked exclusion).

Ainda que a Lei 12.529/2011 não tenha previsão expressa que vede a prática de exclusividade, o artigo 36, $\S 3$, incisos III, IV e $\mathrm{V}$, cita consequências que podem ser alcançadas por meio dos acordos de exclusividade.

\footnotetext{
III - limitar ou impedir o acesso de novas empresas ao mercado;

IV - criar dificuldades à constituição, ao funcionamento ou ao desenvolvimento de empresa concorrente ou de fornecedor, adquirente ou financiador de bens ou serviços;

V - impedir o acesso de concorrente às fontes de insumo, matérias-primas, equipamentos ou tecnologia, bem como aos canais de distribuição [...].
}

Em que pesem as eficiências citadas, os acordos de exclusividade também podem trazer consequências negativas ao ambiente concorrencial. Assim, a autoridade administrativa avalia os efeitos líquidos; isto é, entendidos os efeitos positivos e negativos, sopesá-los-á a fim de avaliar se os efeitos positivos superam os negativos.

A análise dos acordos de exclusividade pela autoridade administrativa é feita em cinco etapas, a saber: (I) a análise do mercado relevante, (II) a existência de posição dominante, (III) a análise do fechamento, (IV) os efeitos negativos líquidos e (V) a sanção. 
Figura 5 - Fluxo da análise dos acordos de exclusividade

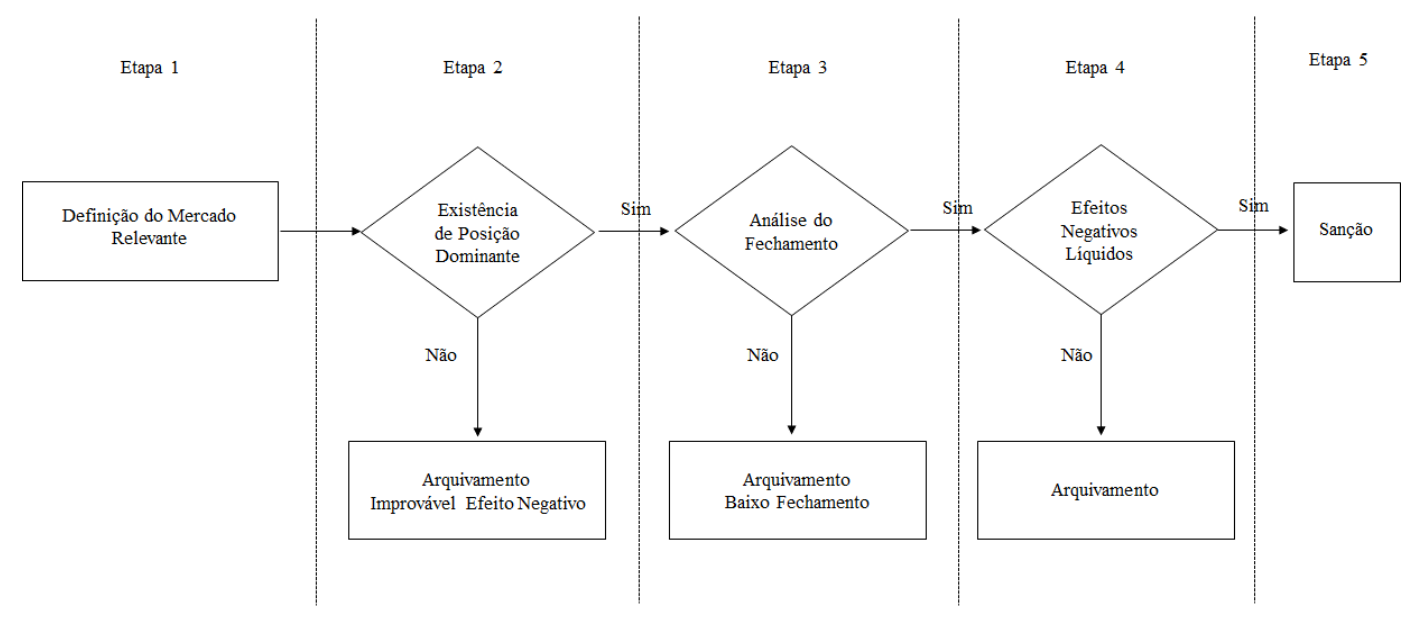

Fonte: elaboração do autor com base no livro Direito Concorrencial (pág. 144).

Os acordos de exclusividade trazem como consequência mais preocupante para a autoridade antitruste, dentre outros efeitos, o fechamento do mercado. Em função disso, há preocupação com a magnitude do fechamento do mercado que o acordo de exclusividade possa promover.

Cada acordo de exclusividade terá um método mais adequado para calcular o fechamento do mercado. Cita-se como exemplo um acordo de exclusividade de um fornecedor de bebidas com os canais de distribuição como bares e restaurantes em determinada região.

O cálculo do índice de fechamento de mercado de tal acordo pode ser realizado pelo quociente entre o volume de vendas marginais de bebidas atingidos pelo acordo de exclusividade e o volume total de vendas de bebidas na região.

Ainda hoje não há um índice de fechamento objetivo que seja considerado aceitável e seguro quanto aos efeitos concorrenciais. A autoridade administrativa realiza análise de forma casuística. Em que pese a importância da análise casuística, a ausência de um porto seguro (safe harbor) prejudica a atividade empresarial ao omitir um parâmetro importante para o planejamento organizacional dos agentes. 
Práticas de exclusividade como, verbi gratia, cooperativas de saúde que, utilizando a força de sua posição dominante, exijam exclusividade na prestação de serviços médicos (Caso Unimed) ${ }^{2}$, e cláusulas de raio ou exclusividade geográfica aplicada por shopping centers (Caso Iguatemi) ${ }^{3}$ foram práticas de exclusividade consideradas ilícitas pela autoridade concorrencial.

Por fim, as autoridades concorrenciais têm preocupação com os acordos de exclusividade que tenham características especiais como, verbi gratia, prazo longo e cláusulas de renovação automática. Ambos propiciam maior fechamento do mercado.

Os acordos de exclusividade de longo prazo propiciam maior fechamento de mercado e em consequência maior restrição ao ambiente concorrencial. Se um fornecedor estabelece com um distribuidor um contrato de exclusividade por prazo de cinco anos, isso significa que durante tal período o distribuidor ficará restrito a comercializar os produtos do fornecedor contratado.

Ainda que surjam novos produtos ou novas condições de um concorrente, o distribuidor não poderá adquirir produtos do novo fornecedor, uma vez que está impedido por um contrato. É despiciendo dissertar sobre o prejuízo aos consumidores finais decorrente do fechamento do mercado.

As cláusulas de renovação automática, também conhecidas como English clauses, têm sido analisadas com atenção pelas autoridades antitruste. Ao estabelecer renovação automática dos acordos de exclusividade, promovem maior fechamento no mercado e a indesejável redução do ambiente competitivo.

\footnotetext{
${ }^{2}$ A frequência de condenações de cooperativas médicas por prática de condutas de exclusividade fez o CADE publicar a Súmula n. 7. "Constitui infração contra a ordem econômica a prática, sob qualquer forma manifestada, de impedir ou criar dificuldades a que médicos cooperados prestem serviços fora do âmbito da cooperativa, caso esta detenha posição dominante."

${ }^{3}$ Processo Administrativo n. 08012.002841/2001-13. Representada: Condomínio Shopping Center Iguatemi e Shopping Centers Reunidos do Brasil Ltda.
} 
A Resolução n. 20 do CADE cita os acordos de exclusividade contemplando os potenciais efeitos anticompetitivos e benefícios.

Dentre os efeitos anticompetitivos a autoridade concorrencial cita a tendência de cartelização quando os acordos de exclusividade dividem mercados entre produtos; outrossim, o aumento do poder de mercado da sociedade empresarial que bloqueou a entrada dos concorrentes nos canais de distribuição.

Como benefícios o CADE cita redução de custos e proteção aos investimentos ao evitar efeitos como o free riding pelos concorrentes.

\subsection{Conduta de Venda Casada}

O artigo 36, § 3, inciso XVIII da Lei 12.529/2011 define a conduta de venda casada: "subordinar a venda de um bem à aquisição de outro ou à utilização de um serviço, ou subordinar a prestação de um serviço à utilização de outro ou à aquisição de um bem".

Utiliza-se para melhor compreensão do tema o exemplo de um grande fabricante de pastas de dente sabor menta que decida inserir um novo enxaguante bucal branqueador no mercado e condicione a venda do novo produto à aquisição da pasta de dente sabor menta.

Num caso como esse, a autoridade fará a análise da prática por meio de quatro etapas, ilustradas na figura a seguir. 
Figura 6 - Fluxo da análise das práticas de venda casada

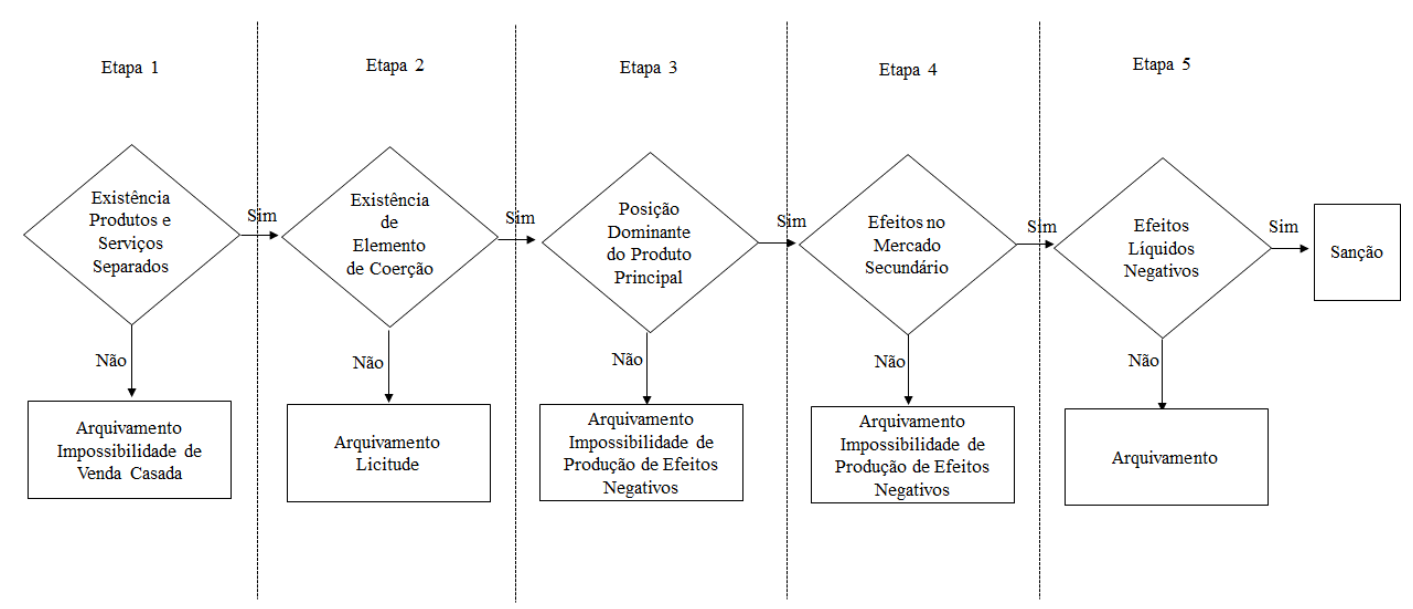

Fonte: elaboração do autor com base no livro Direito Concorrencial (pág. 147).

A primeira etapa consiste na avaliação feita pela autoridade concorrencial quanto à existência dos produtos separadamente. No exemplo estudado, será avaliado se os produtos pasta de dente sabor menta e novo enxaguante bucal branqueador existem e convivem no mercado de forma autônoma.

Observa-se que tais produtos existem autonomamente. Tanto a pasta de dente quanto o enxaguante bucal são independentes, caso não fossem a análise da autoridade concorrencial seria interrompida e a investigação arquivada, uma vez que não se pode cogitar venda casada se não há pelo menos dois produtos autônomos.

Não obstante o exemplo ajude a entender a questão, nem sempre tal compreensão é trivial. Produtos e serviços complexos exigem estudos mais apurados a fim de entender se há autonomia entre eles ou se são somente um produto. Um estudo comumente aplicado, mas nem sempre preciso, é a identificação da demanda dos produtos separadamente. Ainda que os produtos possam ser vendidos separadamente, há especial preocupação com um benefício justificável para o consumidor na comercialização conjunta

Toma-se como exemplo o mercado de carros e peças acessórias como rodas e pneus. Tanto rodas quanto pneus podem ser vendidos separadamente, 
contudo um carro não pode ser vendido sem rodas e pneus, visto que são peças fundamentais para seu funcionamento.

Daí surge o questionamento se são produtos separados ou peças integrantes de um mesmo produto. Em que pese a possibilidade de estudar a demanda dos produtos separadamente, há complexidade na definição da existência autônoma de tais produtos.

A dificuldade no entendimento da autonomia de produtos e serviços, bem como a dificuldade da aplicabilidade do teste de demanda, já foi tema de ampla discussão pela autoridade antitruste norte-americana na ação civil n. 94-1564 United States vs. Microsoft Corp. U.S. District Court.

$\mathrm{Na}$ ocasião existiam dois produtos que eram comercializados separadamente: o sistema operacional e o navegador para internet. No fim dos anos noventa, a Microsoft decidiu integrar o seu navegador Internet Explorer ao sistema operacional Windows.

Representada por venda casada, a Microsoft arguiu que a aplicação do teste de demanda pelos produtos separadamente seria um método de avaliação inadequado, uma vez que o mercado de alta tecnologia é dinâmico e usar como referência a demanda passada significaria impedir inovações que integrassem produtos distintos em benefício dos consumidores.

Após muita discussão sobre o tema e compreendida a complexidade, a Microsoft propôs um acordo com a autoridade antitruste norte-americana a fim de encerrar o processo.

Superado o entendimento da existência de dois produtos independentes, inaugura-se a segunda etapa da análise. Nesta etapa, a autoridade concorrencial avalia se há um elemento de coerção a fim de que os produtos sejam adquiridos conjuntamente.

No exemplo em estudo, se o consumidor puder adquirir a pasta de dente sabor menta e o enxaguante bucal branqueador de forma separada, não 
há que se falar em venda casada, dado que não se estaria condicionando a venda de um à aquisição de outro.

No caso em tela, trata-se de um novo enxaguante bucal branqueador, disponível somente em conjunto com a pasta de dente sabor menta. Isso faz que o consumidor que queira adquirir o novo enxaguante tenha que adquirir a pasta de dente.

Compreendida a existência do elemento coercitivo, a autoridade antitruste avança para a terceira etapa da análise. Nesta etapa, visa a avaliar se o agente tem posição dominante no mercado do produto principal.

Será necessário que a pessoa tenha posição dominante no mercado de pastas de dentes para que ocorram efeitos negativos sobre a concorrência.

Neste ponto, há dois efeitos prejudiciais ao mercado. Primero, o aumento da participação de mercado no produto dominante. Segundo, o crescimento da participação de mercado do produto secundário. A inexistência de posição dominante no mercado do produto principal leva ao arquivamento do processo, uma vez que não seria possível ter efeitos negativos no mercado.

Por fim, a autoridade concorrencial inaugura a análise da quarta etapa. Identificará os efeitos produzidos tanto no mercado do produto primário quanto no mercado do produto secundário.

No mercado secundário, se o consumidor for impelido a adquirir o produto em função da venda casada, é evidente o prejuízo para o ambiente concorrencial. No mercado primário, haverá prejuízo quando a venda casada impedir a entrada de novos concorrentes, havendo assim uma tendência de perpetuidade da posição dominante.

Assim como as demais práticas verticais analisadas, a avaliação final da autoridade concorrencial será feita ao sopesar as eficiências da conduta da venda casada em relação ao efeito anticompetitivo. Se as eficiências superarem os aspectos anticompetitivos, a conduta não será sancionada. 
Nas análises recentes da autoridade concorrencial têm prevalecido as justificativas apresentadas pelos agentes. Nota-se dificuldade da caracterização do ilícito concorrencial, uma vez que é necessário avançar e atender aos requisitos das cinco etapas do processo de análise; não atendido um requisito, a investigação é arquivada.

\subsection{Fixação de Preço de Revenda}

A fim de compreender a conduta vertical denominada fixação de preço de revenda, usa-se um exemplo de uma situação hipotética. Imagina-se um mercado no qual atue um fabricante de refrigerantes que venda seus produtos por meio de canais de distribuição como, verbi gratia, bares.

Em condições normais de mercado, o fabricante vende o refrigerante para os bares, que por sua vez, considerando variáveis de demanda, oferta, custos e clientela, definem o preço a ser vendido aos clientes finais. Trata-se da situação normal em um ambiente de livre concorrência.

Em alguns casos, as autoridades concorrenciais observaram práticas distintas. Notaram que os fornecedores dos produtos tinham alguma influência no preço que o distribuidor cobrava do cliente final. No exemplo em tela, o fabricante de refrigerantes teria alguma gerência no preço dos refrigerantes vendidos pelos bares e restaurantes aos clientes finais.

A legislação concorrencial pátria contemplou tal circunstância no inciso IX do $\S 3$ do artigo 36 da Lei 12.529.

IX - impor, no comércio de bens ou serviços, a distribuidores, varejistas e representantes preços de revenda, descontos, condições de pagamento, quantidades mínimas ou máximas, margem de lucro ou quaisquer outras condições de comercialização relativos a negócios destes com terceiros [...].

Dentre as resoluções antitruste especialmente representadas pela Resolução CADE n. 20, também há menção ao tema: "Fixação de preços de 
revenda: o produtor estabelece, mediante contrato, o preço (mínimo, máximo ou rígido) a ser praticado pelos distribuidores/revendedores."

Passa-se à análise das espécies de fixação do preço de revenda, a saber: preço máximo, preço rígido, preço mínimo e preço sugerido.

A fixação de preço máximo consiste na prática de o fabricante estabelecer o preço máximo de venda do varejista para o cliente final.

Neste caso, o risco de a conduta produzir efeitos anticoncorrenciais consiste nos contextos em que o distribuidor tenha elevado poder de mercado, consiga agregar valor ao produto oferecido e com isso possibilite a cobrança de valores maiores. Ao fixar o preço máximo, o fornecedor pode retirar tais agentes do mercado.

No caso em tela, consistiria na prática de o fabricante determinar que os bares poderiam vender o refrigerante por qualquer preço desde que não excedesse o valor determinado pelo fabricante. Por hipótese, cada lata de refrigerante deveria ser vendida por qualquer preço desde que não excedesse sete reais.

Em que pese tal prejuízo para o ambiente competitivo, a fixação de preço máximo não está entre as condutas que mais preocupam as autoridades antitruste. Tais condutas serão analisadas pela regra da razão; avaliam-se os efeitos negativos e positivos líquidos para o mercado.

Outra espécie de fixação de preço de revenda é a fixação de preço rígido. Neste caso, o fabricante determina o preço de venda a ser cobrado pelo varejista aos clientes finais.

No caso em tela, consistiria na definição pelo fabricante de refrigerantes do preço a ser cobrado pelos bares aos clientes. Por hipótese, seria o fabricante definir que cada lata de seus refrigerantes seria vendida no mercado por cinco reais. 
Com tal prática, nota-se desde $\log o$ a retirada da autonomia do varejista na definição do preço final considerando variáveis como local, clientela, custos do negócio, preços dos concorrentes, dentre outras.

A fixação de preço de revenda rígido também possibilita que os agentes dominantes do mercado ajam em conjunto com práticas como, por exemplo, cartéis. Neste caso utiliza-se a fixação de preço de revenda como mecanismo de controle do pacto entre concorrentes.

A fixação do preço rígido também contribui para que fornecedores construam barreiras que impeçam a entrada de novos distribuidores no mercado.

Outra espécie de fixação de preço de revenda é a fixação de preço mínimo. Trata-se de uma espécie de fixação de preço em que o fornecedor dá ao varejista liberdade para estabelecer o preço final cobrado do consumidor, desde que superior ao valor estipulado pelo fornecedor.

No exemplo em tela, o fabricante dos refrigerantes determinaria que os bares poderiam cobrar qualquer valor para vender os refrigerantes aos clientes finais desde que minimamente cobrassem quatro reais.

Tal definição é anticompetitiva visto que, se um bar quisesse vender um refrigerante por dois reais, estaria impedido pelo fabricante, naturalmente acarretando prejuízo ao consumidor.

Por fim, os agentes de mercado por vezes praticam a conduta de preços sugeridos. Consiste em o fornecedor sugerir um preço ao varejista sendo certo que a sugestão não vincula o distribuidor, tampouco existiriam mecanismos de controle por parte do fornecedor. Trata-se de mera sugestão.

A sugestão de preço de revenda foi tema analisado pelo CADE no início dos anos noventa quando o Sindicato dos Industriais de Panificação e Confeitaria de São Paulo representou a KIBON - Kraft Suchard Brasil S.A. por meio do Processo Administrativo n. 148/1992. 
$\mathrm{Na}$ ocasião, a representante arguiu que a Kibon definiria o preço de venda dos sorvetes nos pontos de distribuição varejistas por meio de tabelas de venda. A Kibon, por sua vez, arguiu que se tratava de preço sugerido de venda ao varejo (suggested retail price), e não prática de tabelamento. $\mathrm{O}$ referido processo administrativo foi arquivado por improcedência da representação.

Neste caso, o fabricante não monitora nem exerce controle algum sobre o preço praticado pelo varejista. A prática de preço distinto do sugerido não traz como consequência nenhum mecanismo de punição pelo fornecedor.

As autoridades antitruste consideram relevante, para fins de avaliação da conduta de fixação de preço, os efeitos intramarcas e intermarcas dos produtos.

$\mathrm{Na}$ avaliação intramarcas, a autoridade antitruste estuda os efeitos da conduta em relação a produtos de um mesmo fabricante. No exemplo em tela, consiste na avaliação dos efeitos da conduta no mercado do refrigerante A em relação ao refrigerante $\mathrm{B}$, ambos do mesmo fabricante.

$\mathrm{Na}$ avaliação intermarcas, a autoridade concorrencial avalia os efeitos da conduta em relação a produtos de diferentes fabricantes. Nota-se desde logo que há efeitos diretos no ambiente concorrencial.

No caso em tela, consiste na avaliação da conduta de fixação de preço de revenda determinado por um fabricante de refrigerantes $\mathrm{C}$ em relação aos bares, considerando os efeitos em relação ao fabricante de refrigerantes $\mathrm{T}$.

Em que pese a existência de potenciais prejuízos ao ambiente concorrencial pela fixação do preço de revenda sob a óptica intramarcas, a maior preocupação da autoridade concorrencial tem sido a avaliação sob o prisma intermarcas. Isso porque os efeitos intermarcas atingem concorrentes distintos, que poderiam promover mais competição no mercado. 
As espécies fixação de preço rígido e especialmente fixação de preço mínimo são as mais preocupantes para as autoridades antitruste, uma vez que têm capacidade potencial de trazer mais prejuízos ao ambiente competitivo.

Em regra, a análise das condutas verticais é realizada à luz da regra da razão, portanto devem ser sopesados os efeitos positivos e negativos para o ambiente concorrencial em decorrência da fixação do preço de revenda.

No que se refere à fixação de preço mínimo, há entendimento recente relevante em um julgamento do CADE. Considerando o maior potencial lesivo ao ambiente concorrencial nas condutas de fixação de preço mínimo, o uso da regra da razão foi excepcionado para aplicar-se a regra do ilícito per se. Nesse caso houve presunção iuris tantum de ilicitude, cabendo à autoridade concorrencial comprovar a existência da conduta.

O leading case que afastou a regra da razão e aplicou do conceito de ilícito per se quando há fixação de preço mínimo foi o Processo Administrativo n. 08012.001271/2001-44, tendo como Representante o PROCON de São Paulo e como Representada a SKF do Brasil Ltda.

A SKF do Brasil é uma indústria especializada na produção de rolamentos automotivos. Ao fornecer rolamentos para seus distribuidores, impôs aos distribuidores preço mínimo de revenda dos produtos aos consumidores finais.

Influenciada pela abordagem europeia presente no Tratado de Bruxelas no artigo 81 n. 3, o CADE entendeu que, na fixação de preço mínimo de revenda, a regra da razão e a análise dos efeitos líquidos utilizada deveria ser excepcionada para a avaliação da conduta por objeto.

À SKF caberia desfazer a presunção relativa (iuris tantum) de que a fixação do preço mínimo traria ganho de eficiência econômica repassada ao consumidor e que não traria prejuízo ao ambiente concorrencial. Não provada tal eficiência econômica pela representada, o CADE aplicou multa de um por cento do faturamento registrado no ano 2000. 
Ao agente que praticou a fixação de preço mínimo cabe desfazer a presunção, seja por meio de arguição de efeitos líquidos positivos, seja pela ausência de poder de mercado capaz de gerar efeitos anticompetitivos.

Notam-se, no caso da fixação de preço mínimo, duas questões relevantes, a saber: a inversão do ônus probatório e a exceção à regra da razão.

A jurisprudência recente do CADE conta somente com o caso SKF para tratar fixação de preços mínimos de revenda como ilícito per se, portanto não se pode afirmar que há mudança definitiva de entendimento da autoridade antitruste quanto à adoção de infração por objeto quando diante da conduta de fixação de preço mínimo de revenda.

\subsubsection{Condutas Predatórias}

\subsection{Condutas Predatórias Clássicas}

A conduta de prática de preços predatórios é comumente associada à política de preços de venda abaixo do preço de custo de um produto. Em tese, uma estratégia irracional, vender e auferir prejuízos.

Não obstante tal definição, a conduta de preços predatórios envolve essencialmente dois elementos, a saber: (I) a prática de venda de produtos abaixo do custo no curto prazo que acarrete prejuízos ao agente e (II) a expectativa de o agente retirar concorrentes do mercado, ulteriormente aumentar o preço e recuperar as perdas auferidas durante a prática de preço predatório.

O estudo da prática de preço predatório à luz da legislação e das normas administrativas pátrias requer a interpretação conjunta de três textos normativos, a saber: (I) Lei 12.529/2011, artigo 36, § 3, inciso XV, (II) Resolução CADE n. 20 e (III) Portaria n. 70 do Ministério da Fazenda - 
Guia de Preços Predatórios do Ministério da Fazenda. Passe-se à análise dos textos.

Lei 12.529. Art. 36. Constituem infração da ordem econômica, independentemente de culpa, os atos sob qualquer forma manifestados, que tenham por objeto ou possam produzir os seguintes efeitos, ainda que não sejam alcançados:

I - limitar, falsear ou de qualquer forma prejudicar a livre concorrência ou a livreiniciativa;

II - dominar mercado relevante de bens ou serviços;

III - aumentar arbitrariamente os lucros; e

IV - exercer de forma abusiva posição dominante.

$\S 3^{\circ}$. As seguintes condutas, além de outras, na medida em que configurem hipótese prevista no caput deste artigo e seus incisos, caracterizam infração da ordem econômica:

$\mathrm{XV}$ - vender mercadoria ou prestar serviços injustificadamente abaixo do preço de custo.

Nota-se pela interpretação conjunta do inciso XV do $§ 3$ com o caput que a venda de produtos abaixo do preço de custo, por si só, não é ilícito concorrencial. A caracterização do ilícito requer que a venda por preço abaixo do custo seja capaz de produzir os efeitos previstos no artigo 36. Inexistentes os efeitos, malgrado a conduta, não há que se falar em ilícito.

A Resolução n. 20 do CADE, por sua vez, ao tratar práticas de preços predatórios, complementa a definição acrescentando o conceito de custo variável médio. Tão importante quanto o acréscimo feito é o reconhecimento pela autoridade administrativa de que nem sempre a prática é ilícita.

Resolução n. 20 CADE. Preços predatórios: prática deliberada de preços abaixo do custo variável médio, visando eliminar concorrentes para, em momento posterior, poder praticar preços e lucros mais próximos do nível monopolista. O exame desta prática requer análise detalhada das condições efetivas de custos e do comportamento dos preços ao longo do tempo, para afastar a hipótese de práticas sazonais normais ou de outras políticas comerciais da empresa, além da análise de comportamento estratégico, avaliando-se as condições objetivas de ganhos potencialmente extraordinários posteriores suficientemente elevados e capazes de compensar as perdas decorrentes das vendas abaixo do custo. (Grifo meu).

O texto normativo traz algumas observações relevantes: (I) nem toda prática de preço abaixo do custo será ilícita; (II) há motivos razoáveis e 
justificáveis que podem fazer um agente adotar preços abaixo do custo; (III) deve-se analisar a prática à luz da regra da razão.

Ainda no campo normativo, passa-se ao estudo do Guia para Análise Econômica da Prática de Preços Predatórios previsto na Portaria n. 70/2002 da Secretaria de Acompanhamento Econômico do Ministério da Fazenda (SEAE).

Ao lançar o guia, a SEAE comunicou que um dos objetivos da adoção deste seria tanto conferir segurança jurídica ao permitir previsibilidade de resultados aos agentes quanto tornar público o critério objetivo adotado pela autoridade antitruste para analisar condutas predatórias.

O guia adotou a análise de preços predatórios em cinco etapas. Uma vez não atendidos os requisitos avaliados em cada etapa, não se admite avançar para as etapas seguintes, devendo-se arquivar o processo. Antes da compreensão de cada etapa, é importante entender o fluxograma do processo.

Figura 7 - Fluxo da análise de prática de preço predatório

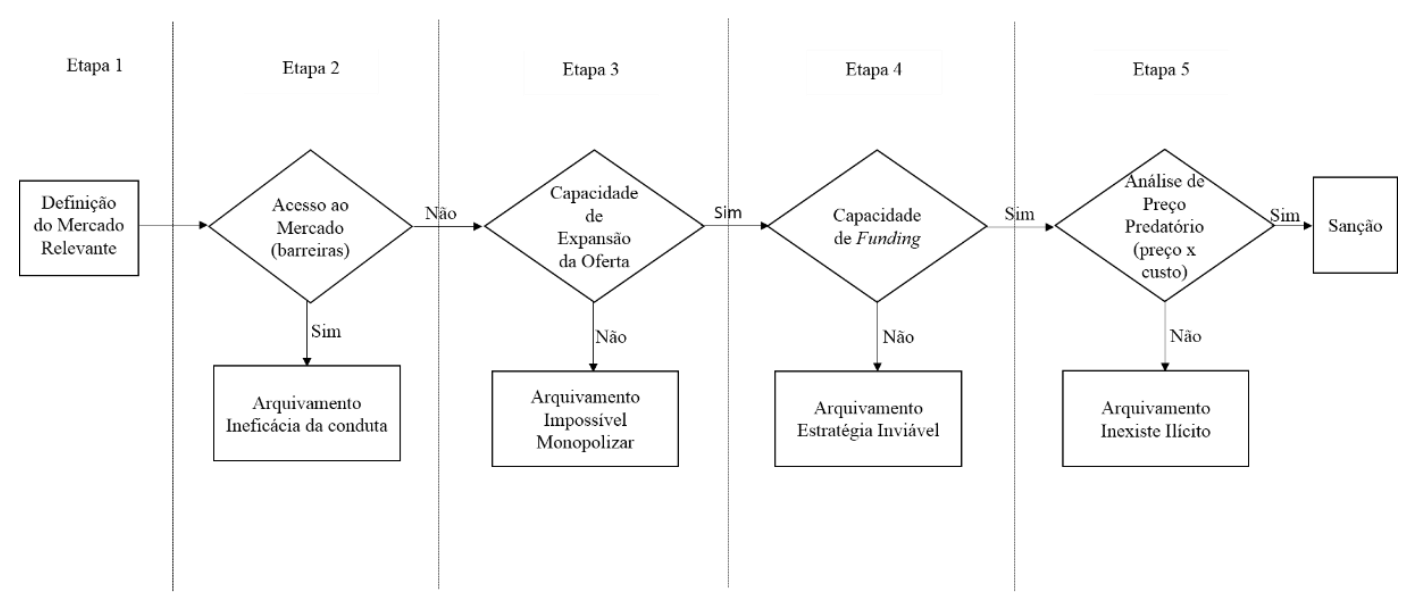

Fonte: elaboração do autor com base no livro Direito Concorrencial (pág. 155).

Conhecidas as etapas utilizadas pela autoridade concorrencial a fim de avaliar a existência de ilícito, passa-se à análise das questões perquiridas em cada etapa.

A primeira etapa consiste na definição do mercado relevante. Trata-se da delimitação do mercado afetado pela conduta do agente. A avaliação do 
mercado afetado e da estrutura do mercado permite identificar se a prática de preços predatórios é possível com produção de efeitos anticompetitivos.

Em análise recente, o CADE entendeu que um agente que detinha dez por cento do mercado relevante não seria capaz de prejudicar o ambiente concorrencial com a prática de preços predatórios. ${ }^{4}$

A fim de melhor compreender o tema, usa-se o exemplo já citado no presente trabalho dos mercados populares nas grandes capitais, em especial os mercados da Saara, no Rio de Janeiro, e na Rua Vinte e Cinco de Março, em São Paulo. Em tais mercados, a estrutura e as condições não permitem a prática de preços predatórios.

A inviabilidade da conduta é observada porquanto, dado o número de concorrentes, ainda que possível praticar preços predatórios, não seria razoável ter como resultado em momento ulterior a monopolização.

A segunda etapa consiste no estudo do acesso ao mercado relevante identificado na primeira etapa. A autoridade antitruste avalia a facilidade que um novo competidor teria para acessar o mercado relevante. Busca-se identificar a existência de barreiras à entrada de novos competidores.

Caso as barreiras sejam baixas ou inexistentes, a autoridade concorrencial arquivará o processo, uma vez que não é razoável imaginar que o agente poderia excluir os competidores e em momento ulterior aumentar os preços.

Em um mercado com barreiras inexistentes ou baixas, novos competidores poderiam entrar cobrando preço mais baixo, com isso o preço tenderia ao ponto de equilíbrio.

No exemplo em discussão, consistiria em um agente em um grande mercado popular praticar preços predatórios durante um período a fim de

\footnotetext{
${ }^{4}$ Em que pese o CADE em 16/11/2017 ter absolvido as sociedades empresariais representadas pela conduta de prática de preço predatório, condenou-as por prática de cartel. Processo administrativo n. $08012.009645 / 2008-46$.
} 
excluir seus competidores. Uma vez excluídos do mercado em função da prática de preços predatórios, o agente aumentaria o preço para recuperar as perdas.

Ocorre que em um grande mercado popular não há barreiras à entrada de novos competidores. Se alguns competidores saíssem do mercado, outros imediatamente entrariam e com isso forçariam o agente predador a continuar com a estratégia por tempo indeterminado, o que levaria a uma situação insustentável a longo prazo para o agente que pratica o preço predatório.

Decorre de tal lógica a iniciativa da autoridade concorrencial em arquivar processos de prática de preço predatório quando identifica que o mercado não tem barreiras ou apresenta baixas barreiras à entrada de novos competidores, uma vez que há o entendimento de que seria insustentável e ineficaz o exercício da conduta no longo prazo.

Se identificada a existência de barreiras à entrada de novos competidores, a autoridade concorrencial passará à análise da capacidade de oferta da sociedade empresarial que pratica preço predatório, a fim de avaliar a capacidade operacional de monopolizar o mercado.

A lógica da análise consiste em supor que o agente pratique o preço predatório a fim de excluir os competidores, monopolizar o mercado e aumentar o preço. Ainda que a intenção fosse monopolizar, o agente teria que ser capaz de aumentar a sua produção a fim de atender todos os demandantes do mercado, uma vez que futuramente seria monopolista.

Se o agente não tivesse capacidade de expandir a sua produção ou não tivesse capacidade ociosa, não teria como atender todo o mercado, portanto seria uma estratégia inviável. A demanda que excedesse a capacidade do agente continuaria sendo atendida pelos demais agentes.

Retoma-se o exemplo de um mercado popular em um grande centro. Ainda que o agente que atue no mercado carioca da Saara praticasse preço predatório e conseguisse excluir os competidores, caso não tivesse 
capacidade de atender todo o mercado em momento ulterior, a estratégia seria inviável. Seria necessário ter capacidade de atender todos os clientes da Saara carioca.

Em função de tal entendimento, a autoridade concorrencial arquiva processos de conduta de preços predatórios, uma vez observada a incapacidade do agente de expandir a produção a fim de atender todo o mercado.

Observada a capacidade de expansão da produção do agente que pratica preço predatório, a autoridade concorrencial inaugura a quarta etapa da análise. Nesta etapa, estuda a estrutura financeira do agente que pratica a conduta.

A prática de preços predatórios faz que o agente tenha prejuízos durante o período da prática até que consiga eliminar o concorrente, tornarse monopolista e aumentar o preço. Isso significa que o agente deve ter capacidade financeira para suportar prejuízos durante o período necessário para excluir os demais competidores.

Tal estratégia pressupõe robusta capacidade financeira do agente que pratica preços predatórios. Primo, porque não sabe quanto tempo deverá manter o preço abaixo do custo. Secundo, porque perderá recursos com base em uma expectativa futura de conseguir obter monopólio do mercado.

Os mecanismos de financiamento (funding) do agente podem contar com recursos próprios, recursos de terceiros ou a composição de recursos próprios e de terceiros.

Se a autoridade concorrencial entender que o agente que pratica o preço predatório não tem estrutura financeira robusta ou não é capaz de se financiar com terceiros para praticar a conduta, fará o arquivamento do processo, uma vez que seria inviável adotar tal estratégica. 
Se a autoridade concorrencial entender que o agente tem capacidade financeira para suportar a prática de preços predatórios, passará à análise da quinta etapa.

As quatro etapas precedentes indicam a possibilidade de prática de preço predatório, todavia a possibilidade não significa a efetiva prática. Buscar-se-á na quinta fase compreender a relação do custo e do preço praticado, a fim de identificar o exercício de preço predatório.

Antes de qualquer análise, destaca-se a dificuldade da autoridade concorrencial em tal etapa. Tal dificuldade ocorre não em função do preço de mercado que é conhecido e sim da estrutura de custos de cada agente. ${ }^{5}$

Em função da dificuldade de compreensão da estrutura de custos do agente, ainda não foi possível observar condenação pela autoridade administrativa pela prática de preços predatórios.

A estrutura de custos envolve informações internas do agente que nem sempre podem ser identificadas pela análise contábil. As estruturas de custos são complexas, admitem métodos distintos para atribuição de custos, divisão dos custos entre linhas de produtos distintos, dentre outras questões que dificultam a identificação pela autoridade concorrencial.

É nesta quinta fase que surge um cuidado especial por parte da autoridade concorrencial. Ao sancionar por prática de preço predatório algum agente que esteja tão somente praticando estratégia para expansão de sua atuação no mercado, prática que beneficia a concorrência e o ambiente competitivo, a autoridade concorrencial estaria inibindo a concorrência, justamente a conduta que deseja evitar.

Daí a análise da relação entre o preço final e o custo ser feita com muito cuidado por parte da autoridade antitruste. O CADE tende a adotar

\footnotetext{
${ }^{5}$ A dificuldade da compreensão do custo das sociedades empresariais mostrou-se presente na investigação sobre preço predatório em condutas de cartéis no mercado de leite. O CADE arquivou em 23/01/2017 a investigação em relação à prática de preço predatório. Processo Administrativo n. 08012.010744/2008-71.
} 
postura conservadora ao fazer tal análise, a fim de evitar que sua atuação iniba a concorrência.

Passa-se à análise da relação do preço e do custo do produto. Dedicase atenção especial aos métodos para estabelecer o custo do produto. Há ao menos dois parâmetros de custo utilizados pela autoridade concorrencial, a saber: (I) o custo variável médio e (II) o custo total médio.

O custo variável médio consiste no quociente entre a soma de todos os custos variáveis e o número de produtos produzidos. Identifica o custo variável para a produção de um produto.

$$
\text { Custo Variável Médio }=\frac{\text { Somatório dos Custos Variáveis }}{\text { Número de Produtos Produzidos }}
$$

O custo total médio consiste no quociente entre todos os custos de produção (fixos e variáveis) e o número de produtos produzidos. Identifica o custo médio total da produção de um produto.

\section{Custo Total Médio = $\underline{\text { Somatório dos Custos Fixos e Variáveis }}$ Número de Produtos Produzidos}

A partir da identificação do custo variável médio e do custo total médio, a autoridade antitruste realizará a análise da prática de preços predatórios por meio da elaboração de faixas de análise. Passa-se ao estudo das faixas.

Na primeira faixa há a identificação do preço praticado acima do custo total médio. Neste caso inexiste preço predatório, uma vez que em tal faixa ocorre o que é almejado por qualquer sociedade empresarial, a saber, o preço de venda acima do custo e consequente geração de lucros. Arquiva-se o processo se identificada tal relação entre custo e preço.

Na segunda faixa há a identificação do preço abaixo do custo total médio e acima do custo variável médio. Neste caso há alguma possibilidade de preço predatório, todavia não há certeza quanto à prática, isso porque há situações que justificam a prática de tais preços. 
Toma-se como exemplo uma redução repentina na demanda. A necessidade de escoar a produção é importante, pois gera receitas para o agente. $\mathrm{O}$ excesso de oferta na indústria seria outra situação que justificaria o preço. Nesses casos há justificativa razoável para o exercício de preço abaixo do custo total e acima do custo variável médio.

Diante da prática de preço abaixo do custo total médio e acima do custo variável total, a autoridade antitruste buscará identificar alguma situação que justifique tal conduta por parte do agente. Identificada justificativa, o processo será arquivado. Não identificada justificativa, será constatada prática de preço predatório e consequente sanção.

Por fim, a terceira faixa consiste na identificação de preços abaixo do custo variável médio. Em tese, o empresário está produzindo e gerando prejuízos, uma vez que o preço sequer cobre o custo de produção. Tal conduta se mostra irracional, visto que nenhuma sociedade empresarial existe com a finalidade de produzir prejuízos para seus sócios.

É nesse sentido que a autoridade concorrencial considera que há real possibilidade de prática de preço predatório por parte do agente quando identifica preço abaixo do custo variável médio.

Ainda assim, há motivos lícitos que podem justificar a prática de preços abaixo do custo variável médio. Toma-se como exemplo a necessidade de escoar estoque de produto perecível que não foi possível comercializar. Justifica-se a prática do preço, afastada a ilicitude.

A figura abaixo sintetiza a análise das três faixas adotadas pelo CADE, bem como a relação entre custo total médio e custo variável médio. 
Figura 8 - Faixas de análise de prática de preço predatório

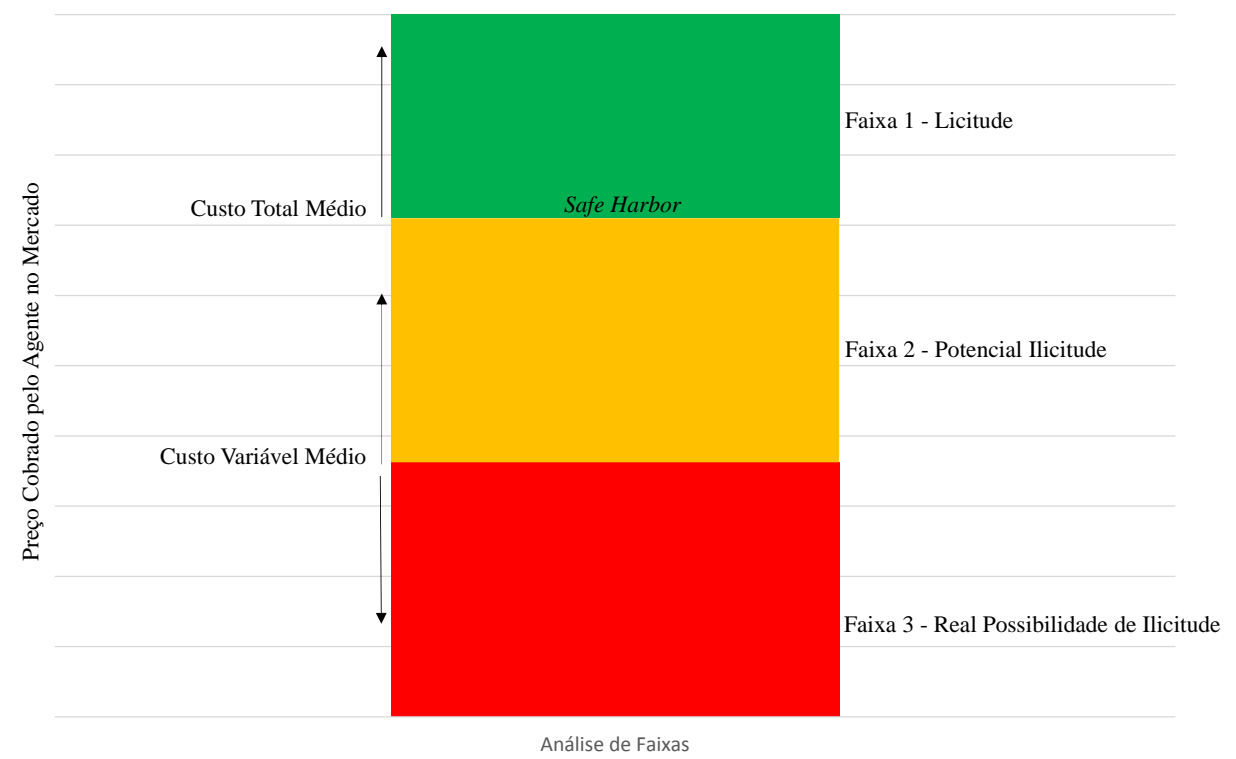

Fonte: elaboração adaptada do autor com base no livro Direito Concorrencial.

\subsection{Novas Teorias de Predação}

Enquanto a prática de preços predatórios clássica utiliza como premissa a existência de competidores e a prática de preço abaixo do custo a fim de excluir concorrentes, as novas teorias de predação partem da premissa de um mercado monopolista.

Neste caso, não há que se falar em práticas de preços a fim de excluir rivais, e sim em uso de preço predatório como meio de impedir a entrada de novos competidores. Trata-se do uso do preço predatório como mecanismo de barreira à entrada de novos competidores.

Dentre as espécies de condutas, a mais observada é a crença de que a pessoa jurídica dominante faz os competidores terem que praticará preços abaixo do custo a fim de proteger o mercado contra novos entrantes. Tratase de uma mensagem aos potenciais competidores sobre a capacidade de proteção do mercado por meio de políticas de preços predatórios.

A espécie recebe críticas das autoridades antitruste, visto que permitiria o reconhecimento de prática de preços predatórios ainda que o 
monopolista praticasse preços acima do custo médio variável, desde que a conduta tivesse por fim criar barreiras à entrada de novos competidores.

Diante da dúvida da existência quer de prática de preço predatório, quer de uma política de preços agressiva, as autoridades concorrenciais tendem a analisar tais casos com parcimônia.

Classificar uma política de preços agressiva como prática de preço predatório significaria coibir reduções de preços que promovam mais competição e bem-estar ao consumidor final; significaria a autoridade concorrencial adotar postura diversa dos seus fins.

\subsubsection{Diversas Práticas de Abuso de Posição Dominante}

A presente pesquisa tem por fim trazer à baila as principais condutas unilaterais e verticais observadas pela doutrina e pelas autoridades antitruste. Em que pese tal finalidade, nem todas as condutas estão presentes no estudo.

A dinâmica do mercado, as técnicas de administração e as políticas empresariais não permitem aos acadêmicos, tampouco às autoridades antitruste, conhecer todas as condutas unilaterais e verticais.

Nada obstante, algumas práticas unilaterais e verticais ainda podem ser citadas em função da frequência observada. Em que pese a prática de tais condutas poder ser classificada como abuso de poder dominante, nem sempre será.

Daí a importância de as autoridades antitruste avaliarem tais condutas à luz da regra da razão. Isso significa aplicar a abordagem de efeitos líquidos para o mercado.

A recusa de contratação adotada por empresas dominantes pode ser considerada conduta ilícita sob a óptica da legislação concorrencial. A prática 
consiste na recusa de fornecer insumos que sejam fundamentais para os concorrentes. ${ }^{6}$

Toma-se como exemplo uma siderúrgica que tenha participação dominante no segmento de mineração. A siderúrgica detentora de participação dominante no mercado de mineração, ao decidir não fornecer minério de ferro para as demais siderúrgicas, reduz a competitividade no setor siderúrgico.

Para que qualquer recusa de contratar não seja considerada conduta anticompetitiva, devem-se compreender alguns requisitos, a saber: (I) capacidade de fornecimento do agente para terceiros; (II) conduta de recusa de contratar pelo monopolista; (III) impossibilidade de o concorrente obter o insumo por outros meios que não a contratação com o monopolista; (IV) o controle dos insumos por um agente monopolista.

Outra conduta vertical que pode ser considerada abuso de posição dominante consiste na redução da margem do concorrente por meio do fornecimento de insumos necessários aos competidores por preços mais elevados ${ }^{7}$. Toma-se como exemplo o já citado caso de uma siderúrgica que atue no segmento de mineração.

Se uma siderúrgica detentora de posição dominante no segmento de mineração decidir fornecer minério de ferro a seus concorrentes a preço mais elevado que o praticado para sua própria siderúrgica, reduzirá a margem dos seus concorrentes.

Tal conduta pode inviabilizar a operação de seus concorrentes, portanto geraria concentração de mercado e prejuízos para o ambiente

\footnotetext{
${ }^{6}$ A Globosat recusou-se a vender para a Associação Neo TV o canal SporTV, que detinha o direito de transmissão dos principais campeonatos de futebol. Com isso retirou insumo insubstituível e fundamental para concorrentes por meio de conduta de recusa de venda. Processo Administrativo n. $08012.003048 / 2001-31$.

${ }^{7}$ Um dos ilícitos investigados pelo CADE no mercado de cimento foi a imposição de preços elevados para concorrentes. Uma vez condenados pela prática de cartel, o princípio do non bis in idem motivou o arquivamento da investigação da prática de fornecimento de insumos para concorrentes a preços mais elevados. Processo Administrativo n. 08012.011142/2006-79.
} 
concorrencial. A autoridade concorrencial deve perquirir o quão razoável ou justificável é a prática de preço superior para o fornecimento de insumo aos concorrentes.

Conduta vertical também potencialmente ilícita consiste na aquisição de insumo que exceda injustificadamente a necessidade do agente a fim de impossibilitar a aquisição de insumo por seus concorrentes.

Ciente da quantidade de insumos de que necessita para produzir, da capacidade de fornecimento por parte do mercado e da demanda de seus concorrentes, um agente pode decidir adquirir insumos em excesso a fim de impossibilitar seus concorrentes de produzir.

Como as demais condutas verticais, tal iniciativa é avaliada à luz da regra da razão. É necessário entender os efeitos líquidos da conduta e, igualmente, se há justificativa para tal prática.

Se um agente demanda uma quantidade de insumos e decide contratar com o mercado cinco vezes a sua necessidade com vistas a garantir fornecimento para expansão da produção prevista com o início da operação de novas fábricas, ainda que tal contratação em excesso reduza a quantidade de insumos disponíveis para os concorrentes, não há que se cogitar conduta ilícita anticompetitiva, uma vez que há justificativa para a conduta que reduz insumos disponíveis no mercado para os concorrentes.

A conduta que as autoridades antitruste visam a punir consiste na aquisição, em excesso, de insumos necessários aos concorrentes com a única finalidade de privá-los de produzir e concorrer.

Por fim e sem pretensão de exaurir o tema, as autoridades concorrenciais têm ficado atentas às políticas de benefícios concedidos por fornecedores mediante condições.

A prática mais conhecida é a concessão de descontos progressivos em função do volume adquirido pelo varejista. A prática por si só não pode ser 
considerada ilícita, pelo contrário, é praxe do fornecedor conceder redução nos preços quando o varejista compra quantidades maiores.

Nesses casos, a preocupação da autoridade concorrencial consiste na prática de concessão de benefícios aos varejistas em função de condições que possam gerar condutas semelhantes aos contratos de exclusividade.

Retoma-se o exemplo estudado nas condutas de exclusividade. Se um fornecedor de refrigerantes contratar com os bares varejistas de tal forma que o benefício dado pela aquisição de produtos inviabilize que outros fornecedores vendam para tais bares varejistas, o agente está realizando um contrato de exclusividade travestido de concessão de benefício condicionado $^{8}$.

Os programas de benefícios condicionados, também conhecidos como programas de fidelidade, são capazes de trazer bem-estar aos consumidores. Políticas como descontos progressivos em função do volume em que o fornecedor aproxime o preço do custo marginal de produção são benéficas.

A conduta a ser evitada são benefícios condicionados não lineares. Nesses casos, os programas excedem a concessão de descontos em função do volume; de alguma forma praticam condutas que restrinjam a concorrência.

São situações como esta que as autoridades concorrenciais desejam evitar, isto é, independentemente da denominação dada à conduta, se de alguma forma esta promover fechamento relevante do mercado, deve ser considerada ilícita sob a óptica concorrencial.

Em síntese, quando a autoridade antitruste está diante de um potencial ilícito concorrencial em função de conduta vertical, uma das principais preocupações será a análise do fechamento de mercado com exclusão dos concorrentes pelo agente dominante. Caberá aos agentes justificar as

\footnotetext{
${ }^{8}$ A Ambev foi condenada pela prática do Programa "Tô Contigo". A multa de trezentos e cinquenta e três milhões de reais foi uma das maiores já aplicadas pelo CADE. Processo Administrativo n. 08012.003805/2004-10 de 22/07/2009.
} 
condutas. Por sua vez o CADE analisará o caso à luz da regra da razão. Sopesará efeitos positivos e negativos da conduta a fim de avaliar os efeitos líquidos para o bem-estar dos consumidores. 


\section{Metodologia de Pesquisa}

\subsection{Tipo de Pesquisa}

O presente estudo utiliza como taxonomia a segmentação da pesquisa quanto aos fins que almeja atingir e quanto aos meios empregados para tal.

Quanto aos fins, a pesquisa é classificada como investigação explicativa, uma vez que tem por objetivo tornar algo inteligível. O presente trabalho tem por fim a compreensão das condutas unilaterais e verticais consideradas ilícitas à luz da jurisprudência concorrencial brasileira.

A ilicitude de condutas unilaterais e verticais inexiste per se, portanto busca-se por meio de investigação explicativa compreender quais características fazem as condutas verticais serem consideradas ilícitas.

Quanto aos meios, a pesquisa adota o método documental e o bibliográfico.

A pesquisa pode ser classificada como documental visto que utiliza documentos de órgãos públicos, especialmente os julgados, atas e publicações da autoridade antitruste brasileira (CADE).

O estudo também pode ser classificado como bibliográfico, pois utiliza-se de material publicado em livros, revistas especializadas, artigos e sítios eletrônicos que tratam temas do direito concorrencial e da regulação antitruste brasileiros.

\subsection{Universo e Amostra}

$\mathrm{O}$ universo da pesquisa compreende as condutas unilaterais e verticais julgadas pelo CADE nos anos de 2016 e 2017. O Tribunal do CADE julgou nove casos em 2016, dentre esses, seis considerados ilícitos concorrenciais. Outros dois casos foram julgados em 2017; somente um considerado ilícito. 
Tabela 1 - Condutas unilaterais e verticais recentes julgadas pelo CADE

\begin{tabular}{cccc}
\hline Ano & Conduta llícita & Conduta Lícita & Total \\
\hline 2016 & 6 & 3 & 9 \\
2017 & 1 & 1 & 2 \\
\hline
\end{tabular}

Fonte: elaboração do autor com base no site do CADE.

Na escolha da amostra utilizou-se critério não probabilístico. A seleção por tipicidade foi adotada, uma vez que, dentre as condenações pelo Tribunal do CADE no período analisado, há casos com características semelhantes como, verbi gratia, TECON Salvador, TECON Rio Grande e TECON Santos.

A fim de evitar a análise de casos semelhantes, buscaram-se condutas unilaterais e verticais com características distintas a fim de compreender como a autoridade antitruste julga tais casos. Com isso, o critério não probabilístico por tipicidade mostrou-se o mais adequado.

\subsection{Seleção de Sujeitos}

Os sujeitos da pesquisa são aqueles que fornecem os dados necessários para o estudo do pesquisador. Uma vez que os dados da pesquisa foram fornecidos pelos votos dos conselheiros do CADE, pode-se considerar o CADE e seus conselheiros como sujeitos da pesquisa desenvolvida.

\subsection{Coleta de Dados}

A coleta de dados foi realizada por meio da literatura sobre condutas unilaterais e verticais. Foram utilizadas publicações em livros, artigos especializados e especialmente os votos dos conselheiros do CADE.

A coleta de dados utilizou a pesquisa bibliográfica como meio para obter os dados necessários para a realização da pesquisa. Os dados foram 
extraídos dos votos dos conselheiros do CADE em conjunto com os pareceres da Superintendência Geral do CADE.

\subsection{Tratamento dos Dados}

A fim de identificar as características das condutas unilaterais e verticais consideradas ilícitas à luz dos julgados do CADE, foi feita a seleção de processos administrativos submetidos ao tribunal da autoridade antitruste referentes às condutas unilaterais e verticais nos anos de 2016 e 2017.

Os votos dos conselheiros foram usados como material de pesquisa a fim de identificar as características das condutas ilícitas realizadas pelas representadas.

A primeira análise consistiu na utilização de distribuição de frequência e estatística descritiva a fim de identificar quais as características mais citadas pelos conselheiros das condutas unilaterais e verticais consideradas ilícitas.

A segunda análise consistiu na utilização de experimento multinomial a fim de identificar se a proporção de uma característica excedia outra característica citada pelos conselheiros.

Se um experimento binomial se caracteriza pela existência de somente dois resultados possíveis, o experimento multinomial tem como característica a possibilidade de mais de dois resultados.

O experimento multinomial produz uma distribuição de resultados multinomial. São características das distribuições multinomiais: (1) terem sido realizadas " $n$ " tentativas repetidamente; (2) a cada tentativa há um número discreto de resultados possíveis; (3) considerando-se qualquer tentativa, a probabilidade de um particular resultado ocorrer será constante; e (4) as tentativas são independentes - o resultado de uma tentativa não interfere no resultado das demais tentativas. 
Toma-se o exemplo de uma criança que tenha colocado em uma bolsa os seguintes brinquedos: cinco cachorros, três gatos e dois cavalos. O experimento da criança consiste em colocar a mão na bolsa e retirar um brinquedo. Após retirar o brinquedo, coloca-o novamente na bolsa e faz o experimento repetidas vezes.

No experimento da criança com seus brinquedos, há três resultados possíveis, a saber: cachorro, gato ou cavalo. A probabilidade de retirar um cachorro será sempre cinquenta por cento, pois são cinco cachorros em um universo de dez brinquedos. A probabilidade de retirar um gato será sempre trinta por cento, pois há três gatos no universo de dez brinquedos. Por fim, a probabilidade de retirar um cavalo é vinte por cento, dado que há dois cavalos dentre os dez brinquedos.

Por fim, os resultados do experimento da criança com seus brinquedos são independentes, pois em uma tentativa retira o brinquedo e logo após o repõe, para fazer nova tentativa. O resultado de uma tentativa não influencia a outra tentativa, cada tentativa é autônoma.

$\mathrm{Na}$ pesquisa, a fim de identificar as características das condutas unilaterais e verticais ilícitas, há " $k$ " possíveis respostas para cada tentativa de identificar as características das condutas ilícitas. Tais características podem ser denominadas classes.

A probabilidade de uma característica permanece a mesma a cada pesquisa feita nos votos dos conselheiros. Destarte, a probabilidade de " $\mathrm{k}$ " característica é a mesma a cada análise de voto, portanto a probabilidade $\mathrm{P}_{1}$ $=\mathrm{P}_{2}=\mathrm{P}_{3}=\mathrm{P}_{4} \ldots=\mathrm{P}_{\mathrm{k}}=1$. As análises de cada voto são independentes.

A variável que interessa ao presente estudo é a contagem do número de observações que estão dentro da mesma classe estabelecida. Assim é possível identificar características comuns às condutas unilaterais e verticais consideradas ilícitas. 


\subsection{Hipóteses}

Foi realizado um teste de hipótese a fim de identificar a proporção de uma característica em relação às outras citadas pelos conselheiros.

A hipótese nula $\left(\mathrm{H}_{0}\right)$ considera que a proporção de uma característica é igual à proporção das demais características das condutas unilaterais e verticais consideradas ilícitas. Assim $\mathrm{H}_{0}=\mathrm{P}_{1}=\mathrm{P}_{2}=\mathrm{P}_{3}=\mathrm{P}_{4} \ldots=\mathrm{P}_{\mathrm{N}}$.

A hipótese alternativa considera que ao menos uma característica de conduta unilateral ou vertical ilícita excede a proporção (1/número de características), portanto existe uma tendência nas características mencionadas pelos conselheiros.

A hipótese é submetida ao teste de distribuição estatística ChiQuadrado $\left(\mathrm{X}^{2}\right)$ a fim de medir o grau de divergência entre os dados da hipótese nula. Em que pese o uso do software IBM SPSS para fazer o cálculo, a fim de aclarar o procedimento indica-se a fórmula usada.

Figura 9 - Fórmula utilizada no teste de hipótese Chi-Quadrado $\left(\mathrm{X}^{2}\right)$

$$
X^{2}=\frac{\left[n_{1}-E\left(n_{1}\right)\right]^{2}}{E\left(n_{1}\right)}+\frac{\left[n_{2}-E\left(n_{2}\right)\right]^{2}}{E\left(n_{2}\right)}+\frac{\left[n_{3}-E\left(n_{3}\right)\right]^{2}}{E\left(n_{3}\right)}
$$

Fonte: elaboração do autor com base no livro Statistics for Business and Economics, 2005.

A interpretação da fórmula é relevante para o entendimento do estudo. Cada variável " $n$ " representa uma característica de conduta unilateral ou vertical ilícita. Quanto mais distante cada característica $\left(\mathrm{n}_{1}, \mathrm{n}_{2}, \mathrm{n}_{3} \ldots \mathrm{n}_{\mathrm{n}}\right)$ estiver de cada valor esperado (np), maior será o $\mathrm{X}^{2}$ e consequentemente maior a chance de a hipótese nula ser negada.

A identificação da zona de rejeição de uma hipótese nula em um teste de hipóteses que utiliza distribuição Chi-Quadrado $\left(\mathrm{X}^{2}\right)$ mostra a área da distribuição que abriga resultados de rejeição de hipótese nula. 
Figura 10 - Distribuição Chi-Quadrado $\left(\mathrm{X}^{2}\right)$

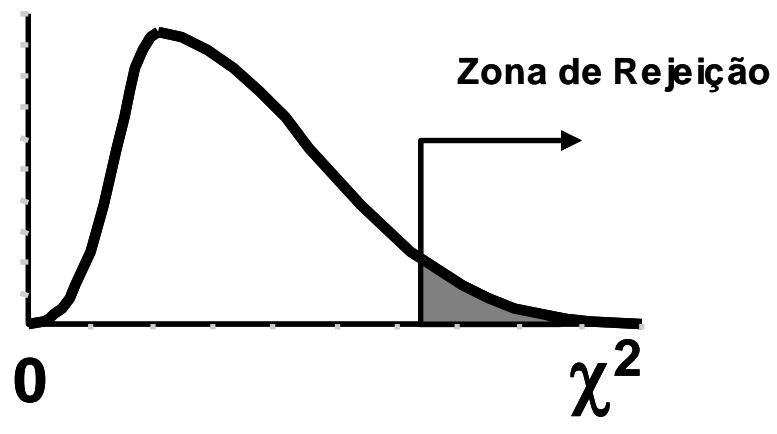

Fonte: elaboração do autor com base no livro Statistics for Business and Economics, 2005.

Utilizou-se grau de significância de um por cento para as características de condutas unilaterais e verticais ilícitas mencionadas nos votos dos conselheiros do CADE. Portanto a probabilidade de erro do procedimento utilizado é de um por cento.

Por fim, destaca-se a utilização do p-value como método para identificar erros no estudo estatístico. O p-value, também conhecido como nível de significância observada, identifica a probabilidade de rejeitar uma hipótese nula sendo a hipótese verdadeira. Em síntese, identifica a possibilidade de conclusão equivocada do pesquisador ao rejeitar a hipótese nula.

\subsection{Limitações do Método}

Recentemente observaram-se diversos ilícitos concorrenciais revelados pelos programas de colaboração premiada oriundos das diversas fases da Operação Lava Jato. A maior parte das ilicitudes concorrenciais descobertas foram formações de cartéis entre empreiteiras para a realização de obras públicas. Tais revelações fizeram as condutas horizontais dominarem as pautas das sessões de julgamento do CADE nos últimos dois anos. 
Considerando-se a necessidade de se julgarem tais casos, as condutas unilaterais e verticais não tiveram tanto espaço nos julgamentos recentes do CADE. Assim, o presente estudo desconsiderou a utilização de método estatístico quantitativo, uma vez que se mostrou inadequado para pesquisas que tenham amostra reduzida. A pesquisa adotou o método qualitativo a fim de analisar as características das condutas verticais consideradas ilícitas pelos conselheiros do CADE.

Em que pese a escolha do método mais adequado, deve-se destacar uma limitação. Os conselheiros podem considerar algumas características de condutas unilaterais e verticais ilícitas, todavia tais características podem não estar presentes na amostra dos casos selecionados. Neste caso, existiria uma característica de conduta ilícita não mencionada pelos conselheiros.

Considerando a preponderância do tempo dedicado pelo CADE à análise de condutas horizontais, a amostra disponível de condutas unilaterais e verticais nos últimos dois anos foi diminuta. A amostra reduzida limita as conclusões do método escolhido para realizar a pesquisa. 


\section{Estudo de Casos}

\subsection{Caso ZF Serviços Ltda. versus ACECOMVI}

É cediço que o Vale do Itajaí, no estado de Santa Catarina, reúne diversas sociedades empresariais produtoras de artigos têxteis. A venda de tais produtos fez surgir um polo atacadista de comercialização de produtos têxteis.

Reunidos nos shopping centers atacadistas e ulteriormente organizados pela Associação de Centros Comerciais Atacadistas de Santa Catarina (ACECOMVI), os centros comerciais atacadistas tornaram-se relevantes na comercialização de têxteis na região.

Os shopping centers atacadistas têm como principais clientes lojistas oriundos de várias partes do país para adquirir produtos no Vale do Itajaí e ulteriormente revender em outros estados.

É necessário aclarar os membros e as alterações nos quadros da ACECOMVI. Inicialmente a ACECOMVI contava com doze shopping centers associados, consoante quadro a seguir.

Quadro 1 - Shopping centers membros da ACECOMVI

\begin{tabular}{cl}
\hline Número & Nome do Centro Comercial \\
\hline 1 & Vitória Régia \\
2 & Vale Europeu \\
3 & All Shopping Atacadista \\
4 & Fabricenter \\
5 & Fetevi \\
6 & Citi \\
7 & Fiti \\
8 & Industrial Blumenau \\
9 & Bruem \\
10 & Indústrias Têxtil do Rio do Sul \\
11 & Stop Shop \\
12 & Passoline \\
\hline
\end{tabular}

Fonte: elaboração do autor com base no voto da conselheira relatora, Cristiane Alkmin, página 4 , parágrafos 59 e 60 do processo administrativo no CADE. 
Após discordância de alguns associados em relação à administração que vinha sendo conduzida pela ACECOMVI, que privilegiava alguns shopping centers ligados a membros da ACECOMVI em detrimento de outros, alguns membros decidiram deixar a associação. Após tais desfiliações, a ACECOMVI passou a contar com seis membros, consoante quadro a seguir.

Quadro 2 - Shopping centers membros da ACECOMVI após desfiliações

\begin{tabular}{cl}
\hline Número & Nome do Centro Comercial \\
\hline 1 & Vitória Régia \\
2 & Vale Europeu \\
3 & All Shopping Atacadista \\
4 & Fabricenter \\
5 & Fetevi \\
6 & Citi \\
\hline
\end{tabular}

Fonte: elaboração do autor com base no voto da conselheira relatora, Cristiane Alkmin, página 4, parágrafos 59 e 60 do processo administrativo no CADE.

A notícia de ilícito concorrencial ocorreu após seis membros solicitarem desfiliação da ACECOMVI. A autoridade antitruste foi noticiada por meio da sociedade empresarial ZF Serviços Ltda., administradora do FITI Shopping, que ônibus de turismo que transportavam clientes atacadistas passaram a ser impedidos de levar clientes aos shopping centers não associados à ACECOMVI.

O exercício de tal impedimento fez a conduta da ACECOMVI ser considerada ilícita à luz do artigo 36, inciso I, e parágrafo 3, inciso IV, da Lei 12.529/2011: “criar dificuldades à constituição, ao funcionamento ou ao desenvolvimento de empresa concorrente ou de fornecedor, adquirente ou financiador de bens ou serviços".

Após a desfiliação da ZF Serviços Ltda., o shopping center por ela administrado teve redução de quarenta e cinco por cento no lucro entre os anos de 2006 e 2007. O representante da conduta, ao investigar os motivos 
da redução no lucro, identificou que esta se deveu a condutas exclusionárias praticadas pela ACECOMVI por meio de seu presidente.

Passa-se à análise do poder de mercado; do mercado relevante; da notícia do ilícito; da conduta da ACECOMVI; do conjunto probatório apurado no processo administrativo e da sanção imposta à ACECOMVI 9 .

O CADE identificou que a ACECOMVI detinha poder de mercado. A uma, tinha elevada representatividade no comércio têxtil local. A duas, atuava como coordenadora do turismo de compras no atacado. A três, realizava o direcionamento dos guias aos centros comerciais associados. A quatro, organizava os repasses de comissões pagas aos guias pelos lojistas. A cinco, realizava cadastro dos guias e lojistas clientes dos centros comerciais. Daí se concluiu a influência da ACECOMVI no turismo de compras por atacado na região do Vale do Itajaí.

A autoridade antitruste definiu o mercado relevante como sendo o Comércio Atacadista de Têxteis no Vale do Itajaí. O turismo de compras tem como agentes importantes os guias de compras que organizam ônibus oriundos de diversos estados para adquirir mercadorias na região. Noventa e cinco por cento das receitas dos centros comerciais provêm de compras feitas pelos turistas atacadistas.

Foram imputadas diversas condutas ilícitas à ACECOMVI. Inicialmente a associação adotou conduta a fim de obstruir a visita dos guias e de seus clientes atacadistas a centros comerciais não associados. Informalmente noticiou aos guias que não deveriam visitar centro comerciais não associados.

A prática deixou o campo informal e tornou-se formal quando a ACECOMVI enviou carta assinada pelo seu presidente à sociedade empresarial Orion Turismo, organizadora de turismo de atacado, informando

\footnotetext{
${ }^{9}$ Processo Administrativo n. 08012.007155/2008-13 julgado em 14/12/2017 pelo CADE.
} 
que os guias deveriam visitar somente shopping centers associados à ACECOMVI.

A ACECOMVI ameaçou os guias com sanção de descredenciamento dos que levassem os clientes atacadistas a outros centros comerciais não associados. Uma vez que o credenciamento era fator importante para os guias, a sanção tinha por fim inibir a presença dos clientes atacadistas em centros comerciais não associados.

Não satisfeita, a ACECOMVI iniciou práticas de retaliações aos guias que visitassem outros centros comerciais. Retaliaram por meio de retenção das comissões a pagar aos guias, atraso no pagamento das comissões ou pagamento com cheque sem fundos para os guias que visitassem outros centros comerciais não associados.

A conduta ilícita não se limitou aos guias. Ao tentar fazer nova associação, foi negada admissão ao FITI Shopping sem nenhuma justificativa. Para tratar o pedido de associação do Catarina Shopping foi convocada reunião dos associados a fim de deliberar sobre a associação, que também foi negada sem justificativa.

Assim, a ACECOMVI impedia o bom funcionamento dos concorrentes, criava barreiras para a clientela frequentar outros centros comerciais e impedia novas associações a fim de inviabilizar a entrada de novos concorrentes e restringir a concorrência, em detrimento do bem-estar do consumidor. Tais condutas ocorreram entre os anos de 2007 e 2010.

Na defesa preliminar e prejudicial de mérito, a ACECOMVI arguiu quatro teses rejeitadas pelo CADE, a saber: (I) prescrição quinquenal, (II) prescrição intercorrente de três anos, (III) uso de provas ilícitas (gravações telefônicas) e por fim (IV) uso indevido de prova emprestada em processos cível e penal.

Afastadas as preliminares no mérito, a ACECOMVI arguiu que é uma instituição sem fins lucrativos e que sua função se limita a filtrar o perfil dos 
clientes que compram nos shopping centers associados. Tal filtragem consistiria no recebimento da lista dos compradores conduzidos pelos guias a fim de consultar a existência de negativação em serviços de proteção ao crédito. Ainda no mérito, arguiu que não houve boicote, e sim preferência da clientela transportada pelos guias para centros comerciais que vendiam somente no atacado.

O conjunto probatório presente nos autos do processo administrativo no CADE foi mais que suficiente para identificar a conduta ilícita da ACECOMVI e de seu presidente. Os conselheiros foram unânimes ao entender a ilicitude e votar pela condenação dos representados.

Destacam-se as principais provas apreciadas no processo administrativo. (I) Gravações de conversas telefônicas entre os guias e sócios de shopping centers não filiados, nas quais estes afirmavam que aqueles não poderiam frequentar outros shopping centers sob pena de retaliação pela ACECOMVI. (II) Os ofícios enviados pela ACECOMVI aos guias foram claros quanto à instrução de não levar clientes aos centros comerciais não filiados. (III) A matéria jornalística do vereador Dejair Machado, do Município de Brusque, informando que a ACECOMVI coagia guias para não levarem clientes aos centros comerciais não associados.

Foi apresentada ao CADE (IV) carta enviada e assinada pelo presidente da ACECOMVI destinada à Orion Operadora informando que, a partir da inauguração do All Shopping Center Atacadista em Gaspar, os clientes deveriam frequentar somente centros comerciais associados à ACECOMVI.

A autoridade concorrencial recebeu (V) a ficha de inscrição dos guias na ACECOMVI. A ficha permitia identificar o controle que a ACECOMVI teria sobre os guias e os clientes. Nos (VI) depoimentos dos Guias no processo penal que investigava o caso, o termo utilizado para a conduta imposta pela ACECOMVI foi boicote. 
A análise contábil (VII) presente nos autos identificou a queda do faturamento do FITI Shopping e o aumento do faturamento do Centro Comercial Vitória Régia, este associado à ACECOMVI e aquele prejudicado pelo direcionamento dos clientes para o associado.

Em que pese a robustez do conteúdo probatório, por amor ao debate, ad argumentandum tantum, ainda restasse dúvida sobre a conduta ilícita, foi levada aos autos (VIII) gravação de conversas telefônicas realizadas entre o presidente da ACECOMVI e os proprietários do Centro Comercial Vitória Régia e do All Shopping, cujo teor consistia na criação de meios para coagir os guias a não levarem clientes aos centros comerciais não associados à ACECOMVI. Tal conversa foi suficiente para decretar a prisão temporária dos envolvidos.

No mérito, o tribunal foi uníssono na condenação por conduta anticompetitiva por parte da ACECOMVI e do seu presidente. A associação criou dificuldade aos concorrentes, outrossim impediu a entrada de novos associados sem nenhuma justificativa. Prejudicou os centros comerciais não associados em detrimento dos associados.

No julgamento, o CADE expressou especial preocupação com o uso de entidades como associações para a realização de condutas ilícitas à luz da legislação antitruste. Tal artifício se mostra especialmente interessante uma vez que a Lei 12.529/2011 utiliza como base de cálculo para aplicar a sanção o faturamento da entidade e não de seus associados.

Segundo a conselheira relatora, Cristiane Alkmin, a penalidade imposta deveria refletir a vantagem auferida pelos associados da ACECOMVI a fim de a penalidade ser eficaz.

Em que pese a importância do método de cálculo da multa, não será abordado no presente trabalho, uma vez que foge ao escopo da pesquisa. Se por um lado a condenação foi unânime, por outro os conselheiros não foram 
uníssonos e abriram divergência sobre o método utilizado para calcular a sanção.

Os conselheiros concluíram pela condenação da ACECOMVI por infração à ordem econômica, violação ao artigo 36, inciso I, e parágrafo 3, incisos III, IV e VIII. À ACECOMVI aplicou-se multa de R\$ 148.974,00 e ao presidente da ACECOMVI dez por cento da multa aplicada à associação, no valor de $\mathrm{R} \$ 14.897,40$.

Para a conselheira relatora, Cristiane Alkmin, vencida no método proposto, a multa deveria considerar a vantagem auferida pelos associados. Os conselheiros reconheceram a necessidade cada vez mais presente da elaboração de um guia de dosimetria de multas aplicadas pelo CADE. Sobre o tema consta a indicação de pesquisas futuras nas sugestões de estudos sobre direitos antitruste.

\subsection{Caso Cade Ex Officio versus Unimed Missões}

Os profissionais que atuam no segmento de saúde, especialmente os médicos, podem optar por trabalho autônomo, emprego no regime CLT ou organização por meio de cooperativas.

No presente estudo dedica-se especial atenção à organização por meio de cooperativas. Trata-se de iniciativa por meio da qual os médicos se reúnem e organizam a atividade por meio de cooperativas médicas.

É inequívoco que a organização de profissionais por meio de cooperativas traz benefícios tanto aos associados quanto aos clientes das cooperativas: para os associados, melhor rentabilidade, e para os clientes, menor custo na prestação do serviço.

Deve-se destacar, desde já, que a organização de profissionais por meio de cooperativas é prática lícita e em muitos casos desejável, uma vez que beneficia tanto cooperados quanto clientes. 
Em que pesem os benefícios do cooperativismo, a autoridade antitruste dedica especial atenção às práticas de cooperativas que excedam seus fins e possam causar prejuízos ao ambiente concorrencial, neste caso as cooperativas poderiam cometer infrações à ordem econômica.

O caso em tela ${ }^{10}$ trata de uma notícia de ilícito concorrencial feita por um funcionário da Empresa Brasileira de Correios e Telégrafos, que informou ter dificuldade de credenciar médicos em Santo Ângelo e nos demais municípios da região de Missões, no Rio Grande do Sul.

O funcionário da Empresa Brasileira de Correios e Telégrafos relatou dificuldade de credenciar médicos para atender funcionários da empresa, visto que a Unimed Missões supostamente exigia exclusividade dos médicos na região. Uma vez credenciado pela Unimed Missões, não poderia ser credenciado por outras operadoras.

A notícia do potencial ilícito levou o Ministério Público Federal (MPF) a propor Ação Civil Pública contra a Unimed Missões. Em função da falta de evidências da conduta de unimilitância (exclusividade) e coação hierárquica, o juiz monocrático proferiu sentença de improcedência em 2014. Nada obstante, em função da especialidade, encaminhou o caso ao CADE.

O caso foi recebido pelo CADE em maio de 2015, e logo foi instaurado processo administrativo. Foi investigada a conduta da Unimed Missões à luz dos ilícitos de prática de exclusividade quando presentes a posição dominante de mercado e a proibição de os médicos se credenciarem em outras operadoras de saúde como meio de bloqueio à entrada de concorrente.

Considerando que o médico é fundamental no serviço de saúde, a vedação do credenciamento retira das demais operadoras o insumo fundamental e insubstituível para atuar no mercado.

\footnotetext{
${ }^{10}$ Processo Administrativo n. 08700.009890/2014-43. Cade Ex Officio versus Unimed Missões.
} 
A prática traz prejuízos consideráveis aos agentes que atuam no mercado. Os médicos, impedidos de trabalhar com outras operadoras, sofrem restrição à livre-iniciativa, valor constitucional tutelado no artigo 1, inciso IV da CRFB. Os clientes são prejudicados, já que a cooperativa reduz a concorrência e as alternativas disponíveis para pacientes, cometendo infração consoante artigo 36, incisos I, II e IV, e parágrafo 3, incisos IV e V, da Lei $12.529 / 2011$.

A unimilitância exigida por cooperativas de saúde tem sido tema frequente nos julgamentos do CADE. Há entendimento pacífico de que a exigência de exclusividade por cooperativas médicas em conjunto com elevado poder de mercado causa prejuízo ao ambiente concorrencial, portanto constitui infração à ordem econômica.

O entendimento é tão pacífico, e os casos, tão frequentes, que a autoridade antitruste entendeu ser oportuno publicar o Enunciado da Súmula n. 7 do CADE, que traz o seguinte conteúdo:

Constitui infração contra a ordem econômica a prática, sob qualquer forma manifestada, de impedir ou criar dificuldades a que médicos cooperados prestem serviços fora do âmbito da cooperativa, caso esta detenha posição dominante.

No mesmo sentido, o STJ por diversas vezes manifestou-se asseverando que "é inválida cláusula contratual inserida em estatuto de cooperativa de trabalho", consoante ERESP n. 191.080.

A exigência de exclusividade não somente é infração contra a ordem econômica, como também viola a legislação dos planos e seguros privados de assistência à saúde presente na Lei 9.656 de 1998. Reza o artigo 18, inciso III do referido texto legal:

Art. 18. A aceitação, por parte de qualquer prestador de serviço ou profissional de saúde, da condição de contratado, referenciado, credenciado ou cooperado de uma operadora de produtos de que tratam o inciso I e o $\S 1^{\circ}$ do art. $1^{\circ}$ desta Lei implica as seguintes obrigações e direitos:

III - a manutenção de relacionamento de contratação, credenciamento ou referenciamento com número ilimitado de operadoras, sendo expressamente 
vedado às operadoras, independente de sua natureza jurídica constitutiva, impor contratos de exclusividade ou de restrição à atividade profissional.

Nota-se que tanto o direito antitruste quanto o regulatório vedam a prática da unimilitância. A Agência Nacional de Saúde Suplementar, preocupada com o tema, também se manifestou pela vedação à unimilitância por meio da Resolução ANS n. 175/2008:

Em se tratando de pessoa jurídica organizada sob a forma de sociedade cooperativa, seu ato constitutivo deverá conter a seguinte cláusula:

Nenhum dispositivo deste Estatuto deverá ser interpretado no sentido de impedir os profissionais cooperados de se credenciarem ou referenciarem a outras operadoras de planos de saúde ou seguradoras especializadas em saúde, que atuam regularmente no mercado de saúde suplementar, bem como deverá ser considerado nulo de pleno direito qualquer dispositivo estatutário que possua cláusula de exclusividade ou de restrição à atividade profissional.

Parece não existir nenhuma dúvida quanto à vedação de práticas de exigência de exclusividade nos casos em que o agente tem posição dominante. No caso em tela, passa-se a avaliar a existência de posição dominante pela Unimed Missões.

O artigo 36, parágrafo 2 da Lei 12.529/2011 presume posição dominante a empresa ou grupo de empresas que controle vinte por cento ou mais do mercado relevante ou seja capaz de alterar unilateralmente ou coordenadamente as condições de mercado.

Considerando o mercado relevante como o mercado de serviços médicos na região de Missões no estado do Rio Grande do Sul, a participação de mercado da Unimed Missões excede vinte por cento em quase todos os municípios, tendo quase sessenta por cento de market share na região.

A tabela a seguir identifica os municípios e a participação de mercado em cada município. Há casos em que a participação da Unimed Missões alcança a totalidade do mercado, portanto não há dúvida quanto ao poder de mercado da cooperativa na região. 
Tabela 2 - Participação de mercado da UNIMED nos municípios

\begin{tabular}{lc}
\hline \multicolumn{1}{c}{ Município } & Participação no Mercado \\
\hline Bossoroca & $31 \%$ \\
Caibaté & $75 \%$ \\
Cerro Largo & $69 \%$ \\
Dezesseis de Novembro & $87 \%$ \\
Entre-Ijuís & $91 \%$ \\
Eugênio de Castro & $89 \%$ \\
Garruchos & $20 \%$ \\
Giruá & $74 \%$ \\
Guarani das Missões & $63 \%$ \\
Itacurubi & $5 \%$ \\
Mato Queimado & $69 \%$ \\
Pirapó & $24 \%$ \\
Porto Xavier & $32 \%$ \\
Rolador & $100 \%$ \\
Roque Gonzales & $50 \%$ \\
Salvador das Missões & $57 \%$ \\
Santo Ângelo & $57 \%$ \\
Santo Ângelo das Missões & $50 \%$ \\
São Borja & $17 \%$ \\
São Luiz Gonzaga & $51 \%$ \\
São Miguel das Missões & $35 \%$ \\
São Nicolau & $56 \%$ \\
São Pedro Butiá & $62 \%$ \\
Senador Salgado Filho & $74 \%$ \\
Sete de Setembro & $79 \%$ \\
Ubiretama & $100 \%$ \\
Vitória das Missões & $98 \%$ \\
Total & $58,57 \%$ \\
\hline &
\end{tabular}

Fonte: elaboração do autor com base no voto do conselheiro Márcio de Oliveira Júnior, pág. 18, parágrafo 79 .

Ao considerar UNIMED Porto Alegre, UNIMED Santa Maria e outras UNIMEDs que atuam na região de Missões, a participação de mercado totaliza aproximadamente setenta e três por cento do mercado. 
Compreendida a inequívoca posição dominante da Unimed Missões no segmento de saúde na região, o CADE analisou o conteúdo probatório a fim de avaliar a conduta de exigência de unimilitância.

Foram identificados relatos de operadoras concorrentes da Unimed Missões, que afirmaram dificuldade de credenciar médicos na região. Dentre as operadoras ouvidas, a Caixa, Cassi, SulAmérica e Assefaz. Algumas citaram que os médicos locais informaram que não poderiam realizar credenciamento em função de exigência de exclusividade da Unimed Missões.

Em função da dificuldade de credenciamento de médicos na região, algumas operadoras tiveram que firmar parceria com a Unimed Missões a fim de ter acesso aos médicos que atuam na região. Foi o caso da Assefaz.

Mister compreender a existência de dois documentos relevantes, a saber: o Estatuto Social da Unimed Missões e o Regulamento Interno da Unimed Missões.

Com o advento da Resolução ANS n. 175/2008 e o novo entendimento do STJ sobre o tema, a Unimed Missões decidiu em 2009 retirar o artigo 15 do estatuto, cujo conteúdo determinava exclusividade por parte dos médicos associados: "Além de outros motivos de direito, a Diretoria é obrigada a eliminar o associado que: (a) Venha a exercer qualquer atividade prejudicial à cooperativa que colida com seus objetivos".

Quanto ao Regulamento Interno da Unimed Missões, foi convocada Assembleia Geral Extraordinária em julho de 2014 a fim de retirar do regulamento interno o artigo 17 e parágrafos, que exigia exclusividade.

ARTIGO 17 - Na obediência de determinações legais e estatutárias, é vedado ao médico cooperado desempenhar atividades conflitantes junto a entidades privadas prestadoras de serviços da saúde de qualquer natureza que faça concorrência à Unimed, ainda que na qualidade de credenciado. (Grifo meu).

PARÁGRAFO $1^{\circ}$ - O médico cooperado que transgredir este artigo será advertido pela Diretoria, tendo o prazo máximo de 10 (dez) dias para optar entre a UNIMED e a entidade concorrente, a partir da data da notificação devidamente protocolada. PARÁGRAFO $2^{\circ}$ - Se, decorrido este prazo, não houver manifestação do 
advertido, ou se este optar pela concorrente, a Diretoria excluirá o cooperado do quadro social, tendo o mesmo o direito a recurso com efeito suspensivo, a ser apreciado na primeira Assembleia Geral extraordinária, convocada para tal fim, desde que interposto o recurso no prazo de 10 (dez) dias após a notificação. (Grifo meu).

Nota-se que entre 2000 e 2009 vigorou cláusula estatutária que exigia unimilitância no Estatuto da Unimed Missões. Entre 2000 e 2014 vigorou no Regimento Interno cláusula que exigia exclusividade, revogada somente em 2014 após o início do processo investigativo pelo CADE.

Em que pesem tais alterações tardias, a cooperativa não se manifestou sobre o artigo 5 do Regimento Interno, que abrigava práticas de unimilitância.

\begin{abstract}
ARTIGO 5 - Não será admitido, como cooperado, o médico que exerça atividade profissional em entidade de assistência médica de natureza "Mercantilista", salvo se, comprovadamente, tenha deixado de integrar o corpo clínico da mesma, inclusive em função administrativa e/ou participações sociais, por 60 (sessenta) meses, em casos de médicos ex-cooperado (sic) e, em 6 (seis) meses, para médicos que nunca tenham integrado o sistema cooperativo.

PARÁGRAFO ÚNICO - De igual forma, o médico ex-cooperado que tenha requerido sua exclusão do Sistema cooperativo e permanecido com consultório na área de ação da Singular, para ser readmitido nos quadros da UNIMED MISSÕES, deverá cumprir o prazo de 60 (sessenta) meses contados da data em que postular oficialmente o seu retorno, preenchendo todos os demais requisitos exigidos para admissão, nos termos do artigo anterior.
\end{abstract}

Identificou-se que a conduta de exclusividade encontrou meios de subsistir, seja pela prática informal, seja mesmo com fulcro no artigo 5 do Regulamento Interno, que criava barreiras para novos entrantes.

A própria UNIMED Missões confirmou que havia prática de exigência de exclusividade ao ter regras societárias que excluíam os que trabalhavam com outras operadoras. Conquanto a supressão dos artigos 15 e 17 do Estatuto e do Regulamento Interno, respectivamente, a conduta de exigência de unimilitância permaneceu, seja pela prática informal, seja pelo artigo 5 do Regulamento Interno. 
A conduta da cooperativa dificultou a entrada de novos competidores. Apesar de ser cooperativa, não poderia atuar a fim de prejudicar a concorrência. A cláusula contratual não poderia gerar efeitos negativos à coletividade.

Em síntese do processo, a defesa em preliminares arguiu trânsito em julgado do caso com efeito erga omnes na Justiça Federal. A arguição foi rejeitada, visto que é pacífico que a instância administrativa é autônoma em relação à instância cível e penal. Outrossim, o CADE destacou que o juiz federal encaminhou o caso ao CADE em função da especialidade do tema.

No mérito, a defesa da Representada com frequência arguiu que a decisão de unimilitância era de seus cooperados e que não tinha nenhuma influência ou poder sobre tal decisão. Alegou que a UNIMED Missões se limitava a atuar estritamente nas funções de uma cooperativa sem nenhum ilícito anticoncorrencial.

Sobre a defesa de mérito da Representada, destaca-se o parecer da SG CADE no SEI 0144746, consoante trecho abaixo:

\begin{abstract}
A Unimed parece, contudo, tentar transferir a responsabilidade pela decisão aos seus cooperados, como se fosse possível a existência de uma personalidade jurídica autônoma e com capacidade de decisão independente de seus membros. Trata-se de uma falácia. A tentativa de revestir essas regras de legalidade por terem sido criadas pelos próprios cooperados esbarra no fato de que a personalidade da cooperativa é apenas uma ficção jurídica, incapaz de poder decisório próprio. Toda e qualquer decisão tomada a respeito da atuação da cooperativa parte, em sua origem, de cooperados em Assembleia Geral.
\end{abstract}

A Superintendência Geral do CADE (SG), o ProCADE e o Ministério Público Federal foram uníssonos quanto ao parecer pela condenação da Unimed Missões por infração à ordem econômica nos termos do artigo 36, incisos I, II e IV, e parágrafo 3, incisos IV e V, da Lei 12.529 de 2011.

Entenderam que a exigência de exclusividade em um mercado relevante em que haja poder dominante do agente é capaz de trazer prejuízos ao ambiente concorrencial. Não somente limita o acesso de novas 
operadoras, como também cria dificuldades de funcionamento e desenvolvimento de operadoras concorrentes.

O tribunal do CADE condenou a Unimed Missões por prática de ilícito contra a concorrência. No cálculo da pena, considerou a sensibilidade do setor, uma vez que presta serviços de saúde, fundamentais para a dignidade da pessoa humana.

O tribunal do CADE também considerou ausência de boa-fé, dado que o Ministério Público por diversas vezes requereu retirada das cláusulas de unimilitância e não foi atendido. As reiteradas decisões do STJ sobre o tema e a existência do Enunciado da Súmula n. 7 do CADE são inequívocos quanto à vedação da unimilitância.

Por fim, considerou a reincidência da representada, condenada tanto pelo CADE quanto pela ANS em momentos pretéritos, e a condição financeira identificada pelo último faturamento, da ordem de sessenta e sete milhões de reais. Assim, impôs sanção de multa pecuniária de seis milhões e duzentos mil reais, além de algumas obrigações de não fazer, dentre as quais se destacam: (I) abster-se de exigir exclusividade; (II) abster-se de dificultar que operadoras façam credenciamento com seus cooperados; (III) abster-se de boicotar os planos de saúde; e (IV) abster-se de realizar descredenciamento em massa.

\subsection{Caso Shopping Center}

É importante conhecer quatro características de um shopping center antes de discutir a questão concorrencial. $\mathrm{O}$ entendimento de tais características é fundamental para compreender a questão concorrencial.

Primeira, um shopping center tem como principal receita a locação do espaço para os lojistas que desejam comercializar seus produtos. Segunda, um importante ativo de um shopping center é a composição do seu tenant mix. Terceira, a construção de um shopping center requer capital intensivo; 
o empreendedor espera retorno do capital investido em determinado período. Quarta, um shopping center atua em um mercado denominado mercado de dois lados.

As receitas de um shopping center são oriundas preponderantemente da locação do espaço. Ainda que em um mesmo contrato de locação exista remuneração fixa e variável, para fins didáticos separam-se tais receitas a fim de compreender as receitas e o problema concorrencial que se estuda a seguir.

A receita fixa da locação compreende um valor prefixado que o lojista paga ao shopping center a fim de usar o espaço para comercializar seus produtos. Ainda que o lojista não tenha sucesso nas vendas, terá que pagar a locação, pois inexiste relação entre o valor pago e o faturamento da loja.

A receita variável da locação consiste em percentual do faturamento da loja que o lojista paga ao shopping center. Trata-se de um percentual, pactuado com a administração do shopping center, que incide sobre o faturamento da loja.

Os casos estudados pela autoridade concorrencial brasileira indicam que há variação no percentual que incide sobre o faturamento das lojas, todavia encontrou-se com frequência a alíquota de cinco por cento. Utilizase no presente trabalho tal percentual, ciente de que há negociação entre as partes.

Figura 11 - Espécies de receitas dos shopping centers

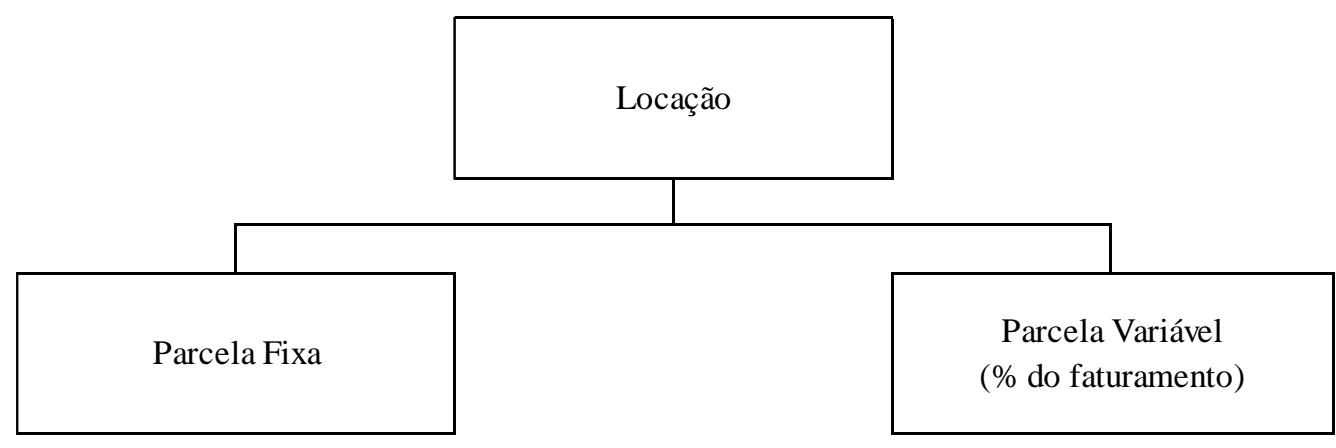

Fonte: elaboração do autor com base no voto do relator do processo no CADE, conselheiro Márcio de Oliveira Júnior, parágrafo 59, página 6. 
Em que pese a comum associação entre shopping center e cláusulas de raio, o estudo histórico do tema indica que a prática inicia ainda nos anos trinta nos EUA por proprietários de lojas situadas nas ruas. Após a crise de vinte e nove, o mercado de locação apresentava elevada vacância. Cientes de que os locatários não poderiam assumir custos fixos, os proprietários passaram a admitir contratos de locação que tinham como remuneração um percentual do faturamento do locatário, em contrapartida estabeleciam cláusulas de raio a fim de proteger as receitas da locação.

A disposição das lojas, as marcas presentes, as espécies de lojas são ativos fundamentais em um shopping center. A esse conjunto, denominado tenant mix, há natural preocupação do shopping center em protegê-lo a fim de não permitir que concorrentes copiem a estrutura elaborada.

O emprego do capital intensivo para adquirir um terreno, construir um shopping center e criar uma marca tem como premissa o retorno do investimento em prazo considerado razoável pelo empreendedor. Neste sentido, os shopping centers buscam afastar situações que criem dificuldade para retorno do investimento feito.

Por fim, o mercado de shopping center é caracterizado como um mercado de dois lados, pois há relação entre integrantes de pelo menos dois mercados distintos. De um lado, os lojistas, que locam o espaço para comercializar seus produtos; e de outro, os consumidores do varejo.

Outros tantos mercados como, verbi gratia, as operadoras de cartão de crédito, que atuam no mercado com os titulares dos cartões e os proprietários do comércio, ou os canais de televisão, que atuam na geração de conteúdo e na comercialização de espaço publicitário, são exemplos de mercado de dois lados.

Ciente da importância do tenant mix, da expectativa de retorno do investimento em determinado período e das receitas fixas e variáveis 
oriundas das locações, a indústria de shopping centers utilizou cláusulas de raio em seus contratos.

A cláusula de raio (radius clause) consiste na vedação ao locatário de iniciar/instalar/manter outro estabelecimento congênere ou similar no mesmo ramo de atividade em um espaço territorial definido no contrato. Notam-se três aspectos na cláusula de raio, a saber: temporal, subjetivo e territorial.

Nasce então o debate sobre a conduta vertical que potencialmente gere restrições à concorrência. Ao vedar que um lojista tenha loja similar em determinada distância, pode-se restringir a concorrência.

A restrição à concorrência ocorre por meios distintos. Aos lojistas impede a abertura de novas lojas similares, o que afronta o valor constitucional da livre-iniciativa previsto no artigo 170 da CRFB.

Aos concorrentes cria-se uma barreira de entrada, uma vez que, ao limitar que uma loja/marca possa estar presente em determinado raio, há impedimento de um shopping center concorrente ter tais lojas. Pode-se criar um monopólio do shopping que tem direito de exclusividade àquela loja.

O fechamento do mercado, questão tão debatida e combatida pela autoridade antitruste brasileira, pode ocorrer por meio das cláusulas de raio, que podem ser também compreendidas como cláusulas de exclusividade.

A questão é especialmente difícil de ser avaliada dado que de um lado está a autonomia da vontade, shopping centers e lojistas têm plena capacidade para determinar os termos de seus contratos, a relação é regida pela pacta sunt servanda e amparada pelo artigo 54 da Lei 8.245/1991; de outro lado estão as questões concorrenciais, especialmente a Lei 12.529/2011, que não podem ficar indiferentes aos efeitos negativos líquidos das cláusulas de raio. Passa-se ao debate sobre o tema.

O estudo da jurisprudência do CADE identifica que cláusulas de raio devem ser analisadas à luz da regra da razão. Destarte, devem ser 
considerados os efeitos positivos e negativos da prática a fim de compreender os efeitos líquidos para o bem-estar do consumidor.

O CADE entendeu, em processos administrativos precedentes ${ }^{11}$, que o uso de cláusulas de raio seria anticompetitivo quando ausente racionalidade nos parâmetros de espaço, tempo e objeto, isto é, ramo de atividade, marca e sujeito.

Há de considerar os limites de razoabilidade quanto à questão temporal, ao objeto e à área geográfica contemplada pela cláusula de raio a fim de avaliar seus efeitos líquidos.

No mesmo sentido está a decisão recente do Superior Tribunal de Justiça $^{12}$. Em que pese não ser uma decisão tomada sob a sistemática de recurso repetitivo, o STJ entendeu que as cláusulas de raio não podem ser consideradas abusivas sem uma análise casuística.

O STJ entendeu que deve haver racionalidade que fundamente a imposição da cláusula de restrição. Os limites deveriam ser observados à luz da liberdade de contratar em conjunto com a livre concorrência. O CADE, por sua vez, já manifestou que cláusulas de raio que não estabelecem limite temporal são consideradas ilícitas.

O Supremo Tribunal Federal não se manifestou expressamente sobre cláusulas de raio, todavia, por meio do Enunciado da Súmula Vinculante n. 49, tangenciou o tema: “Ofende o princípio da livre concorrência lei municipal que impede a instalação de estabelecimentos comerciais do mesmo ramo em determinada área".

Conhecidas as características de funcionamento de um shopping center, seus ativos e a jurisprudência sobre o tema, passa-se à análise do caso concreto submetido à apreciação do CADE.

\footnotetext{
${ }^{11}$ Neste caso, o Tribunal do CADE se referiu aos Processos Administrativos n. 08012.009991/9882; n. 08012.006636/97-43 e n. 08012.002841/2001-13.

${ }^{12}$ Questionado por meio da jurisdição, o STJ decidiu o tema por meio do REsp n. 1535.727/RS, de relatoria do Ministro Marcos Buzzi.
} 
O Ministério Público Federal representou contra um grupo de shopping centers situados em Porto Alegre sob o argumento de suposto comportamento abusivo de direitos que promovia fechamento do mercado na capital gaúcha, infringindo o artigo 36, inciso I, e parágrafo 3 , inciso III, da Lei 12.529/2011.

Notícia veiculada em jornal de grande circulação na capital gaúcha informava que um grande shopping center da região suspenderia o contrato com locatários que abriram lojas em shopping center concorrente que se teria instalado na frente do shopping center onde os lojistas já tinham pontos de venda.

Ao abrir novas lojas em shopping center concorrente, os lojistas estariam infringindo a cláusula de raio que vedava a instalação de lojas a dois quilômetros de raio do shopping center que já tinha as lojas que pretendiam instalar-se também no novo shopping center.

Os estudos do CADE identificaram um problema adicional. Parte relevante do município de Porto Alegre estava abrangida nas cláusulas de raio dos shopping centers instalados na cidade. Uma análise sumária dos raios no mapa da capital gaúcha mostrou que as regiões com maior Índice de Desenvolvimento Humano (IDH) eram abarcadas pelas cláusulas de raio.

Figura 12 - Área de Porto Alegre abrangida por cláusulas de raio 


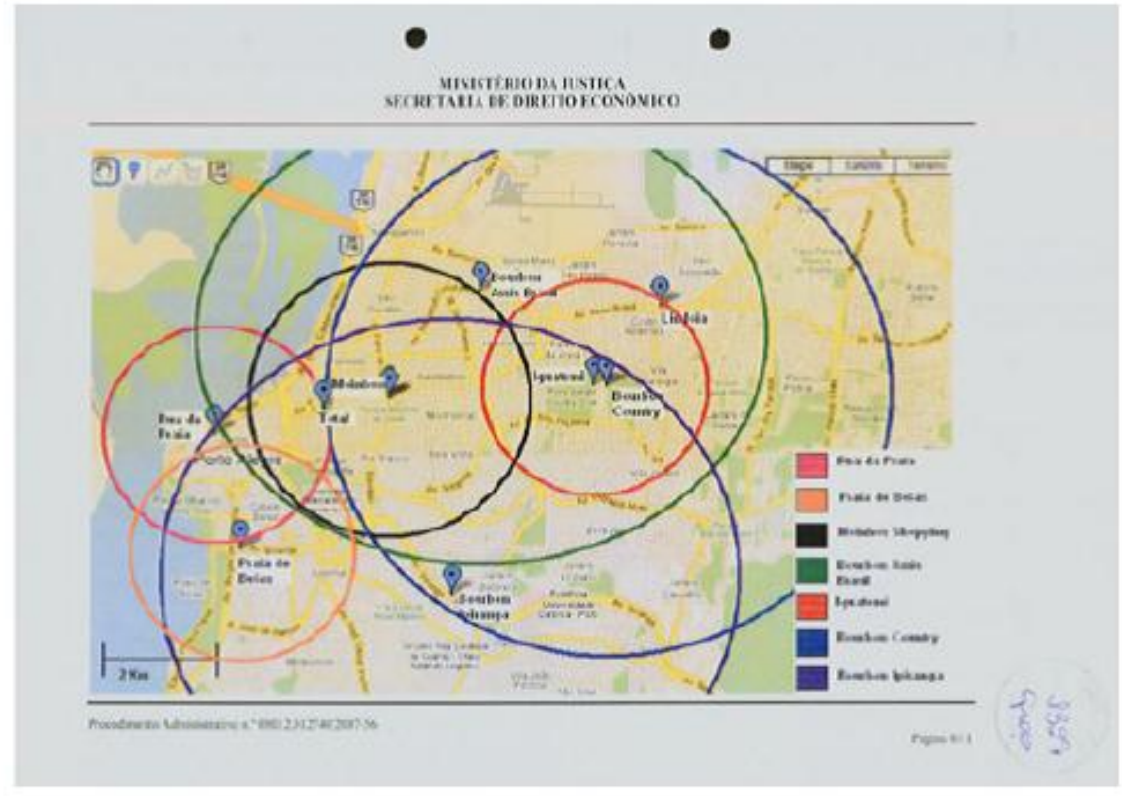

Fonte: voto do conselheiro relator, Márcio de Oliveira Júnior, § 51, página 5.

Nesse contexto foi instaurado um processo administrativo para apurar a ilicitude do uso de cláusulas de raio pelos shopping centers presentes na capital gaúcha. A Superintendência-Geral do $\mathrm{CADE}^{13}$, o Ministério Público Federal e a ProCADE foram uníssonos pela condenação da conduta. Destaque para a divergência do Ministério Público e da conselheira Cristiane Alkmin, que, não obstante concordes quanto à condenação, entenderam a conduta como ilícita per se.

No mérito, o CADE dividiu a análise considerando: (I) o aspecto territorial, (II) os sujeitos, (III) a vigência e a (IV) a forma de contratação entre as partes. Passa-se à análise de cada ponto abordado pelo CADE.

No aspecto territorial, as cláusulas de raio vedam que o lojista desenvolva atividade comercial em determinado raio. Tal dimensão varia

\footnotetext{
${ }^{13}$ A Nota Técnica n. 144 da Superintendência-Geral do CADE trouxe proposta relevante para a análise do tema. Cláusulas de raio com extensão de até dois quilômetros, com duração de até cinco anos e que abarquem somente os controladores da locatária e a marca definida são aceitas. Por sua vez, cláusulas com extensão de raio superior a cinco quilômetros e que incluam acionistas ou sócios não controladores ou outros estabelecimentos do mesmo locatário de marca diversa não serão aceitas. Por fim, raios maiores que dois e maiores que cinco quilômetros com duração superior a cinco anos deverão ser analisados caso a caso, conforme parâmetro mencionado.
} 
entre dois e cinco quilômetros dentre os shopping centers analisados. Careceu de maiores fundamentos e justificativas dos shopping centers o critério utilizado para a definição do raio.

Quanto aos sujeitos, a autoridade concorrencial observou que a vedação não se restringia aos locatários que assinaram o contrato, mas abarcava também qualquer atividade comercial similar que estes exerçam direta ou indiretamente.

Tal situação poderia, verbi gratia, vedar que um locatário de uma loja que comercialize roupas femininas abrisse/mantivesse outra loja, com outra marca, que comercializasse roupas masculinas no raio estipulado pela cláusula. Nota-se, desde já, falta de razoabilidade na vedação.

Quanto à vigência das cláusulas, a maior parte era silente sobre o tema, vinculando a vigência ao tempo do contrato da locação; outras estabeleciam tempo indeterminado. Na prática, as restrições não tinham limites temporais, eram perenes, vigiam por tempo indeterminado.

Por fim, o CADE procurou compreender se tais cláusulas eram fruto de livre negociação entre as partes ou se eram imposições das administradoras de shopping centers. O estudo dos contratos de locação evidenciou que os contratos eram da espécie adesão, alguns com edição somente no campo nome do locatário, data e assinatura das partes.

Em que pesem tais questões, o CADE empregou, consoante jurisprudência da autoridade antitruste, a análise por meio da regra da razão. Outrossim, buscou identificar os efeitos líquidos das cláusulas de raio na locação de lojas nos shopping centers. Destarte, necessário compreender o mercado relevante do tema em discussão.

O mercado de shopping center tem características que o diferenciam do mercado de lojas estabelecidas nas ruas. A segurança do local, a disposição das lojas, a estrutura climatizada, os banheiros, dentre outras 
características, diferenciam um shopping center de lojas estabelecidas nas ruas.

Nesse sentido, a autoridade administrativa entendeu que não há que considerar lojas estabelecidas nas ruas como substitutas de lojas que estão instaladas em shopping centers. São mercados distintos e não substitutos, não concorrem entre si. A jurisprudência do CADE já se tinha manifestado neste sentido em momentos anteriores ${ }^{14}$.

A autoridade concorrencial avançou na análise e identificou que, mesmo entre shopping centers, nem todos concorrem entre si. Isso ocorre pois os shopping centers são segmentados em função de vários critérios, dentre os mais conhecidos listados na Associação Brasileira de Shopping Centers (ABRASCE): área bruta locável (ABL) e tipo de shopping (tradicional ou especializado).

Nota-se que o mercado relevante de shopping centers em discussão é o mercado de shopping centers tradicionais que abarca como subcategoria os shopping centers regionais, comunitários e de vizinhança. Shopping centers especializados que abarcam as espécies outlet, temático e life style/festival center não estão no mesmo mercado relevante.

A exclusividade resultante das cláusulas de raio presentes em contrato de locações em shopping centers tradicionais é capaz de impedir que outro shopping center tenha acesso aos insumos fundamentais para os shoppings, as lojas. Igualmente, limita que o lojista abra/mantenha outra loja no raio estipulado no contrato de locação.

No entendimento da autoridade concorrencial, os contratos privados entre capazes devem ser respeitados, todavia devem ser analisados à luz da legislação concorrencial. As administradoras de shopping centers e os lojistas não podem pactuar indiferentes aos efeitos concorrenciais.

\footnotetext{
${ }^{14}$ Em julgamentos pretéritos o CADE já tinha consolidado entendimento de que lojas situadas nas ruas não competem com lojas situadas em shopping centers; neste sentido, os Processos Administrativos n. 08012.002841/2001-13, n. 08012.009991/1998-82, n. 08012.006636/1997-43.
} 
Compreendido o mercado relevante, o CADE passou ao estudo do poder de mercado dos locadores.

Em que pese a presunção legal de que um agente tenha ao menos vinte por cento do mercado relevante para ter poder de mercado, a autoridade concorrencial manifestou-se pelo afastamento de tal presunção, uma vez que se trata de presunção relativa (iuris tantum).

O CADE entendeu por bem analisar o poder de mercado no caso concreto à luz de outros critérios igualmente importantes e mais adequados que o market share. A melhor avaliação é o poder de mercado dos shopping centers em relação aos lojistas.

Neste ponto o CADE identificou algumas questões que caracterizavam o poder de mercado das administradoras de shopping centers em relação aos lojistas.

A uma, o poder de mercado restou claro, uma vez que os contratos de locação eram firmados por meio de contratos de adesão. Tivesse o lojista algum poder de mercado não se submeteria a firmar um contrato de adesão, discutiria cláusulas, condições e o contrato final seria produto da vontade das partes, e não somente do locador.

A duas, as restrições geográficas compreendidas pelo perímetro do raio mostraram-se imposições unilaterais sem nenhuma negociação entre as partes. A análise dos contratos não mostrou evidência alguma de que houve negociação do espaço de restrição do lojista.

A três, a imposição de cláusula de raio por período indeterminado foi uma evidência do poder de mercado do locador em relação ao lojista. Um critério que obedecesse à razoabilidade entre partes iguais em um contrato teria a cláusula de raio restrita ao período de recuperação do investimento feito pelo shopping center.

A quatro, a amplitude do objeto do contrato no que se refere à cláusula de raio, capaz de abarcar não somente a atividade específica do lojista como 
também atividades similares, como conjuntos de marcas e ramos de atividade, impõe uma exclusividade ilimitada, excluindo potenciais concorrentes no raio. Não tivesse um poder de mercado significativo, não seria possível impor tal restrição.

A cinco, identificou-se assimetria não somente entre shopping center e lojista como também entre lojistas distintos presentes no mesmo shopping center.

É sabido que algumas lojas/marcas são capazes de atrair consumidores para os shopping centers. Algumas com maior outras com menor poder de atração de clientela, todavia todas com alguma contribuição para a criação de externalidades positivas para o shopping center. As lojas comumente denominadas âncoras apresentam maior potencial de geração de externalidades positivas em relação às lojas satélites.

As lojas âncoras tinham como regra a inexistência de cláusulas de raio, enquanto as lojas satélites tinham como regra a existência de cláusulas de raio. Conclui-se que as lojas âncoras, sabidamente dotadas de maior poder de barganha, não se sujeitaram às cláusulas de raio. Foi mais uma evidência da imposição do poder de mercado das administradoras dos shopping centers.

A seis, os mecanismos de coerção destinados a fazer valer as cláusulas de raio foram mais uma evidência do poder de mercado das administradoras de shopping centers; dentre os mecanismos, a multa, que gera pressão concorrencial negativa no mercado.

A sete, observou-se que os efeitos das cláusulas de raio demonstravam inequívoco poder de mercado das administradoras. Geravam fechamento do mercado, criavam barreiras, possibilitavam a criação de monopólio do shopping center sobre determinada marca. Uma vez que os contratos eram impostos pelo locador, a ausência de acordo entre as partes gerava efeito negativo. 
Retomam-se nesta ocasião os três pontos que as cláusulas de raio supostamente visam a proteger, a saber: (I) a receita da locação do espaço para os lojistas que desejam comercializar seus produtos; (II) a composição do tenant mix e (III) a garantia de retorno do capital investido em determinado período. Analisam-se tais pontos à luz das cláusulas de raio.

A proteção da receita da locação tem como preocupação a receita variável que decorre da aplicação de um percentual sobre o faturamento do lojista. A administradora do shopping center toma como premissa que o lojista abrirá uma loja na região do shopping center a fim de desviar seu faturamento para tal loja e com isso não pagar ao shopping o percentual sobre a venda previsto na parcela variável no contrato de locação. Tratar-se-ia de uma falha de mercado derivada da assimetria de informação entre o shopping e o lojista (moral hazard).

A preocupação não faz sentido por vários motivos. Primeiro, o lojista teria que assumir um novo custo de locação ou compra de espaço fora do shopping, além de funcionários e estrutura. Tal custo, quase sempre, será maior que o percentual poupado pelo desvio do movimento do shopping center para a loja. Não encontra abrigo racional dobrar o custo fixo para desviar um percentual do faturamento. Quanto mais próximo do shopping, maior o custo de locação do lojista.

Segundo, a presença em um shopping center leva em conta a existência de externalidades positivas; a cobrança variável de percentual sobre o faturamento alinha interesses do lojista e do shopping.

Nota-se que o desvio de clientela para loja próxima ao shopping center se mostra improvável. Ainda que, por esforço argumentativo, fosse possível pensar em tal situação, há outras formas distintas da cláusula de raio para evitar tal situação. Poder-se-ia pensar na redução da parcela variável e aumento da parcela fixa na locação, dentre outras soluções. 
No que se refere à proteção do tenant mix, a cláusula de raio também carece de fundamentos sólidos para justificar a restrição concorrencial. Quanto ao argumento de que o tenant mix é propriedade intelectual do shopping center, deveria caber ao Instituto Nacional da Propriedade Industrial (INPI) tal reconhecimento.

A proteção de agentes que visam à inovação é justificada nos mercados em que há algum sentido a existência de um monopólio por certo período de tempo. São os chamados monopólios técnicos como, verbi gratia, proteção de patente de um medicamento.

Tais proteções se justificam uma vez que a não proteção desestimularia o investimento por parte das empresas que investem em pesquisa e desenvolvimento (P\&D) de produtos que logo poderiam ser copiados. Em que pese tal preocupação, nota-se que não se está diante de uma questão de saúde pública, educação, segurança ou nenhum outro fator que mereça a tutela do Estado.

Há, neste caso, um contrato entre privados; a tutela do Estado no uso de cláusulas de raio representaria a garantia de redução de risco dos shopping centers, a qual não se justifica à luz das preocupações do Estado.

A probabilidade de replicação do tenant mix é baixa, todavia, ainda que remota, se ocorresse, os shopping centers poderiam concorrer em outras dimensões como, verbi gratia, serviços, facilidades, estacionamento, dentre outros benefícios.

Quanto à garantia de retorno do capital investido em determinado período, a cláusula de raio também carece de fundamentos. Qualquer investimento está sujeito a algum grau de risco. As elevadas taxas de retorno dos shopping centers são compatíveis com o elevado risco assumido pelo empreendedor.

Tutelar a existência de cláusulas de raio seria mitigar o risco do investimento em shopping centers ou garantir retorno de investimentos. A 
mitigação de retorno de investimentos deve ocorrer somente em situações excepcionais, em que haja interesse direto do Estado na realização da atividade em função do bem-estar gerado para a população. A construção de shopping center não está em tal categoria.

Se os shopping centers alegam que as cláusulas de raio são indispensáveis para o sucesso do empreendimento, ficam sem resposta os inúmeros shopping centers bem-sucedidos existentes no Brasil que não utilizam cláusulas de raio. Garantir proteção a investimentos em shopping centers teria como consequência garantir proteção a outros setores, o que vai contra os fundamentos do direito concorrencial.

O CADE concluiu que cláusulas de raio com extensão territorial injustificada, vigência por período indeterminado e imposição do contrato por parte do locador como contrato de adesão configuram ilícito contra concorrência, previsto na Lei 12.529/2011.

As administradoras de shopping centers representadas que assinaram contratos com cláusula de raio foram condenadas por ilícito contra concorrência. Na dosimetria da pena foram consideradas questões como, verbi gratia, tempo de aplicação da cláusula, coerção e sanção imposta no contrato, existência de judicialização do conflito como indício de imposição da cláusula, grau de lesão ou perigo de lesão ao mercado, a situação econômica do infrator, reincidência e a individualização da conduta.

Além da multa pecuniária, os representados foram condenados a cientificar os lojistas que assinaram contratos com cláusulas de raio que tais cláusulas foram retiradas do contrato e cientificar todos os lojistas do tenant mix que cláusulas de raio não serão inseridas em instrumentos contratuais assinados entre o shopping center e lojistas. 


\subsection{Caso Tecon Rio Grande S.A.}

Antes de adentrar na questão concorrencial que envolveu o operador portuário Tecon Rio Grande, é importante conhecer as características de uma operação de comércio exterior e de seus agentes.

Toma-se como exemplo a importação de mercadoria. O processo inicia quando o importador adquire mercadorias que estão no exterior. Para que as mercadorias sejam enviadas ao Brasil, o importador contrata armadores para a execução do serviço de transporte marítimo.

Uma vez contratado o serviço de transporte marítimo, os armadores, responsáveis por enviar a mercadoria ao Brasil, contratam os operadores portuários. Os operadores portuários são concessionários de terminais portuários responsáveis pela operação de descarga dos navios, bem como pela movimentação em terra dos contêineres.

Além da execução da descarga dos navios, os operadores portuários são responsáveis também pelo recebimento da mercadoria e pela entrega no local onde a mercadoria será armazenada. Nota-se, desde já, que os operadores portuários realizam dois serviços distintos e autônomos, a saber: a descarga dos navios com a movimentação em terra até o local de armazenagem dos contêineres e a armazenagem dos contêineres.

Uma vez que o operador portuário que realiza descarga e movimentação em solo é escolhido pelo transportador marítimo (armador), cabe ao importador avaliar a contratação do serviço de armazenagem dos contêineres com o operador portuário ou terceiros.

Faculta ao importador contratar a armazenagem dos contêineres com o próprio operador portuário (armazenagem em zona primária) ou contratar tal serviço com as Estações Aduaneiras Interiores (EADIs) (armazenagem em zona secundária), também denominadas portos secos (dry port).

Quando o importador decide contratar a armazenagem com uma EADI, a carga chega ao operador portuário e, por meio do Regime de 
Declaração de Trânsito Aduaneiro (DTA), logo é enviada ao porto seco contratado. É nesta espécie de operação que nasce a questão concorrencial em discussão.

Quando o importador decide contratar uma EADI para fazer o armazenamento dos contêineres, o operador portuário preterido cobra da EADI uma taxa denominada taxa de serviço de armazenagem de contêineres de importação retirados em menos de quarenta e oito horas, em regime de DTA.

A cobrança consiste em um valor percentual de $0,41 \%$ sobre o valor CIF (Cost, Insurance and Freight) das mercadorias presentes no solo do operador portuário que ali permaneçam por menos de quarenta e oito horas.

Ocorre que, se as mercadorias fossem armazenadas pelo próprio operador portuário por período de até quinze dias, pagariam o mesmo valor percentual de $0,41 \%$ sobre o valor CIF.

A conduta do operador portuário Tecon Rio Grande S.A. fez que a EADI MultiArmazéns Ltda. e a Transportadora Simas Ltda. noticiassem à autoridade antitruste brasileira ilicitude concorrencial ao cobrar taxa de armazenamento sobre mercadoria em solo do operador portuário retirada em menos de quarenta e oito horas.

Antes do julgamento do caso pelo CADE, o STJ ${ }^{15}$ julgou ilícita a cobrança de taxa de armazenagem de quinze dias sobre mercadoria em regime de DTA pelos operadores portuários. Ao julgar o caso, o STJ contribuiu com o entendimento do tema. Destacam-se os principais pontos do julgado.

Primeiro, entendeu a cobrança ilícita, dado se tratar de cobrança por serviço não prestado. Segundo, identificou a cobrança como prejudicial ao ambiente concorrencial. Terceiro, entendeu que a cobrança desestimula o

\footnotetext{
${ }^{15}$ A discussão sobre a licitude da cobrança da taxa de armazenamento de mercadorias em regime de DTA tinha sido submetida ao CADE por meio do Recurso Especial n. 1.181.643 - RS.
} 
rápido desembaraço e ulterior envio para uma EADI, uma vez que, permanecendo ou não por mais de quarenta e oito horas, há pagamento da taxa de armazenagem por período de quinze dias.

Além da decisão, o STJ contribuiu para o entendimento e a distinção entre os conceitos de carga pátio e carga armazenada. A carga pátio consiste em uma mercadoria ainda não recebida e não armazenada, uma vez que está na área demarcada e sob jurisdição da Receita Federal do Brasil. Nesse sentido, não pode receber cobrança de carga armazenada por período de quinze dias. Trata-se de carga em trânsito.

$\mathrm{O} \mathrm{CADE}^{16}$ iniciou a análise do caso pela definição do mercado relevante. O operador portuário Tecon Rio Grande S.A. atua em dois grandes segmentos de serviços autônomos: descarga dos contêineres e movimentação em terra (mercado upstream) e armazenagem alfandegada dos contêineres (mercado downstream).

Uma vez que a definição do operador portuário é do armador e ao importador cabe a definição da armazenagem na zona primária com o operador portuário ou na zona secundária com as EADIs, o mercado relevante foi definido como o de armazenagem alfandegada (mercado downstream) na região do Porto do Rio Grande.

Definido o mercado relevante e considerando tratar-se de conduta unilateral, o CADE procurou identificar a existência do poder de mercado da Tecon Rio Grande S.A.

Primeiro, ciente de que a escolha do operador portuário compete ao armador, compreende-se que, uma vez escolhida, o operador portuário tem poder de mercado e monopólio sobre a descarga e movimentação em solo, portanto há poder de mercado.

\footnotetext{
${ }^{16}$ Julgamento do Processo Administrativo n. 08012.005422/2003-03.
} 
Segundo, os contêineres recebidos pelo operador portuário são insumos essenciais aos que realizam armazenagem alfandegada. Uma vez que as EADIs não têm acesso ao mar e necessitam dos contêineres, os operadores portuários têm capacidade de impor condutas anticompetitivas.

A participação da Tecon Rio Grande S.A. no mercado de armazenagem alfandegada, utilizando o critério de área alfandegada disponível na região, era de 32,5\%. No ano de 2002, a Tecon Rio Grande S.A. foi responsável por $95,5 \%$ da movimentação total de contêineres no porto. Restou inequívoco o poder de mercado da Tecon Rio Grande S.A.

A análise da conduta da representada foi dividida em dois períodos. $\mathrm{O}$ primeiro, compreendido no período em que vigia o prisco Regulamento de Exploração do Porto do Rio Grande. O artigo 96 do referido regulamento dispunha sobre o critério temporal da armazenagem e a remuneração do serviço.

Art. 96. A remuneração pelo serviço de armazenagem será estabelecida e divulgada pelo depositário e será sempre devida desde o dia de entrada das mercadorias nos armazéns de qualquer natureza até o dia a sua saída.

Observa-se, desde já, que o Regulamento de Exploração do Porto do Rio Grande vigente até o ano de 2002 permitia a cobrança de armazenagem desde a entrada das mercadorias nos armazéns até a sua saída. Durante tal período não foi possível identificar ilicitude na cobrança da taxa de armazenamento pelas operadoras portuárias.

Com o advento da Instrução Normativa n. 248/02 da Secretaria da Receita Federal (SRF), o termo inicial da cobrança foi modificado. O artigo 71 fez nova previsão.

Art. 71. O prazo de permanência de carga em área pátio é de vinte e quatro horas contadas, nos dias úteis, a partir da chegada da carga nessa área.

$\S 1^{\circ}$. Excedido esse prazo e não registrada e desembaraçada a declaração de trânsito, a carga será armazenada.

$\S 2^{\circ}$. Havendo motivo que o justifique, a fiscalização aduaneira poderá determinar o armazenamento da carga que se encontre no pátio ou verificar o seu conteúdo. 
$\S 3^{\circ}$. O prazo estabelecido neste artigo será de quarenta e oito horas nos portos alfandegados.

O parágrafo terceiro expressamente determina que a remuneração do operador portuário inicie somente quando a carga permanecer no pátio por mais de quarenta e oito horas. Destarte, a partir do dia vinte e cinco de novembro do ano de 2002 a cobrança pode ser considerada ilícita também sob a análise do prisma jurídico.

Em que pese a mudança na legislação, a Tecon Rio Grande S.A. não alterou a cobrança; manteve a taxa de armazenamento de $0,41 \%$ sobre o preço CIF de cargas em DTA que permaneciam no pátio por menos de quarenta e oito horas como se a permanência fosse de quinze dias.

Compreendidas a alteração na legislação e a conduta do operador portuário representado, o CADE passou à análise dos efeitos da conduta. Como conduta unilateral, mister sopesar efeitos positivos e negativos para o ambiente concorrencial. Foram identificados três efeitos negativos.

Primeiro, a conduta da Tecon Rio Grande tendia a excluir do mercado os recintos alfandegados de armazenagem não vinculados ao operador portuário. A cobrança da taxa de armazenagem de $0,41 \%$ sobre o preço CIF por período de quinze dias, malgrado o contêiner permaneça menos de quarenta e oito horas, desestimula os importadores a optar pelo regime de DTA e ulterior envio dos contêineres para uma EADI independente, pois representa custos adicionais.

A potencial exclusão dos recintos alfandegados independentes reduz a variedade dos serviços disponíveis aos importadores, pois as EADIs são especializadas e oferecem serviços que os operadores portuários não ofertam. Ao excluir os recintos alfandegados independentes, os operadores portuários têm menos concorrentes ou até mesmo podem tornar-se monopolistas no segmento de armazenagem, portanto tendem a elevar o preço do serviço de armazenagem alfandegada. 
Segundo, a atividade de movimentação de contêineres no solo do operador portuário já era devidamente remunerada pelo importador, pois além do frete paga ao armador o Terminal Handling Charge (THC). O THC nada mais é que o custo da movimentação em solo do contêiner pelo operador portuário. Assim, a cobrança da taxa de armazenamento de cargas em trânsito no pátio torna-se uma fonte de recurso extra da atividade de movimentação de contêineres previamente remunerada.

Terceiro, é possível identificar o poder do operador portuário de elevar o custo dos concorrentes no segmento de armazenagem alfandegada. Ao cobrar das EADIs a taxa de armazenamento de $0,41 \%$ sobre o preço CIF, o custo dos serviços das EADIs já inicia $0,41 \%$ sobre o preço CIF maior que o custo da prestação do mesmo serviço por parte dos operadores portuários.

O poder de elevar o custo dos concorrentes não somente afeta os concorrentes presentes no mercado, como também desestimula a entrada de novos concorrentes. Prejudica o ambiente concorrencial presente e futuro ao reduzir a atratividade do setor.

A cobrança da taxa de armazenamento de contêineres retirados em menos de quarenta e oito horas do local do operador portuário tornou ainda maior o poder de barganha da Tecon Rio Grande S.A. em relação aos demais concorrentes no segmento de armazenagem alfandegada, especialmente às EADIs. Prejudica diretamente os concorrentes e indiretamente o consumidor final.

Considerando tal análise, o CADE julgou ilícita a cobrança de taxa de armazenamento de contêineres retirados em até quarenta e oito horas do pátio do operador portuário, consoante artigo 36, incisos I, II e IV, e parágrafo 3, incisos III, IV e XII, da Lei 12.529.

A autoridade concorrencial definiu multa de $\mathrm{R} \$ 4.788 .450,00$ a ser paga em trinta dias, bem como a publicação em meia página no jornal Zero Hora do extrato da decisão condenatória por dois dias seguidos, por duas 
semanas consecutivas. Conquanto o fato ter ocorrido na vigência da Lei 8.884/94, a dosimetria da sanção pôde considerar a Lei 12.529/11 ulterior mais benéfica.

Ao fixar a sanção, o CADE levou em consideração a elevada gravidade da infração, a ausência de boa-fé do operador portuário, a consumação da vantagem indevida, o valor da vantagem indevida, o grau de lesão à livre concorrência nacional, a situação econômica do infrator e os efeitos econômicos produzidos no mercado.

\subsection{Caso Consórcio Gemini}

O entendimento do funcionamento do mercado de gás natural precede a discussão concorrencial que envolve o caso. É necessário compreender a utilização do gás natural e os níveis da cadeia produtiva.

O gás natural é usado como combustível para geração de energia elétrica, geração de calor e processos industriais. Também pode ser utilizado em veículos, como o Gás Natural Veicular (GNV), e para aquecimento de ambientes comerciais ou residenciais.

Os produtos substitutos são aqueles capazes de transformar algum tipo de energia em energia térmica como, verbi gratia, o Gás Liquefeito de Petróleo (GLP) e o óleo combustível. Sabidas as características do gás natural, passa-se ao entendimento da cadeia produtiva.

A cadeia produtiva do gás natural pode ser dividida em três etapas, a saber: exploração de áreas naturais, produção e envio para as refinarias (upstream); processamento e transporte em gasodutos (alta pressão) a fim de distribuir o gás natural (midstream); por fim, distribuição local do gás natural por meio de dutos (baixa pressão) ou a granel. O nível upstream não está no escopo da discussão concorrencial. 
Após a produção do gás natural, a Petrobras coloca-o em gasodutos que percorrem longas distâncias. Em determinados pontos, os gasodutos têm aberturas que permitem direcionar o gás natural para as distribuidoras locais. A distribuição local é feita por empresas que atuam na ponta da cadeia produtiva; são os que têm contato direto com o consumidor final.

A figura ilustra um gasoduto de alta pressão. Após passar pelo duto principal, o gás é redirecionado até o distribuidor local, que por sua vez comercializa o gás natural para o consumidor final.

Figura 13 - Saída do gás do duto de alta pressão para distribuição local

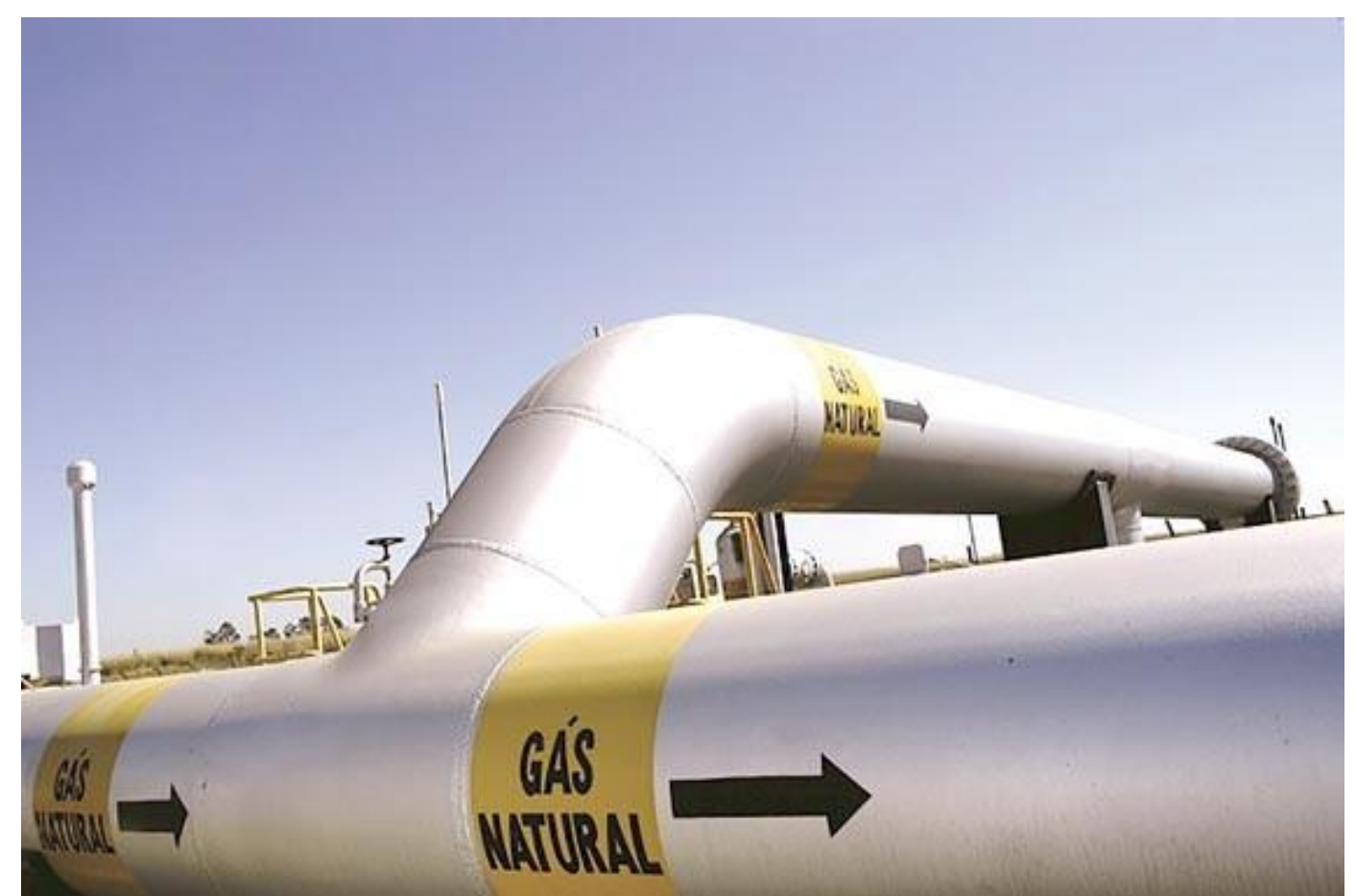

Fonte: site da Agência Alagoas publicada no dia 07 de janeiro de 2016, disponível no link $<$ http://www.agenciaalagoas.al.gov.br/noticia/item/229-algas-inicia-as-obras-dogasoduto-penedo-arapiraca-nesta-segunda>.

Pode-se notar que a Petrobras tem o monopólio de distribuição do gás natural por meio dos gasodutos de alta pressão. Ao direcionar o gás natural para uma distribuidora local, cobra pela venda do produto, neste ponto há a primeira discussão comercial: o preço cobrado para cada distribuidora local. 
Uma vez que o distribuidor local receba o gás natural do duto principal, a distribuição ao consumidor final pode ser feita de duas formas, a saber: dutos de baixa pressão ou a granel.

Numa avaliação preliminar, poder-se-ia entender que a distribuição do gás natural por meio de dutos ou a granel seriam substitutas, todavia tal conclusão é equivocada. A distribuição a granel envolve não somente custos com compressão e transporte como também perdas na liquefação; é, portanto, mais onerosa que a distribuição por meio de dutos.

$\mathrm{Na}$ compressão do gás natural para armazenamento e ulterior distribuição a granel, pode-se usar o gás natural comprimido (GNC) ou o gás natural liquefeito (GNL).

$\mathrm{Na}$ distribuição a granel, o GNC e o GNL são complementares. O GNC mostra-se mais vantajoso quando se trata de distribuição de baixa demanda e curta distância. Por sua vez, o GNL é mais vantajoso quando há longa distância e baixa demanda. Por fim, a distribuição mais vantajosa quando há transporte por longa distância e elevados volumes será por gasodutos de alta pressão.

Em que pesem tais distinções, é possível observar que há uma zona de concorrência entre as distribuições do gás. Entre GNC e GNL, a competição é contínua entre duzentos e trezentos quilômetros, entretanto, se instalado duto, a distribuição a granel deixa de fazer sentido, uma vez que é mais onerosa. Isso faz que o distribuidor a todo instante avalie a viabilidade de instalar dutos em vez de fazer a distribuição a granel.

Tal dinâmica permite duas conclusões: se há duto disponível, a distribuição a granel não faz sentido, uma vez que é mais onerosa; o distribuidor local é monopolista na comercialização por dutos de baixa pressão, ainda que outros concorrentes possam comercializar o gás a granel.

Compreendida a dinâmica do mercado, surge a necessidade de entender os envolvidos na discussão concorrencial. De um lado, como 
representada, a Petróleo Brasileiro S.A. (Petrobras), White Martins Gases Industriais Ltda. e a GNL Gemini e Comercialização e Logística de Gás Ltda.; de outro, a representante Companhia de Gás de São Paulo - Comgás.

Em 2004 foi submetida ao $\mathrm{CADE}^{17}$ a formação de uma joint venture denominada GásLocal (estrutura societária quarenta por cento propriedade da Petrobras e sessenta por cento propriedade da White Martins). A GásLocal era parte do Consórcio Gemini, que também tinha como membros a Petrobras e a White Martins.

O funcionamento do consórcio dava-se, na primeira etapa, pelo fornecimento do gás natural pela Petrobras diretamente à White Martins. Na segunda etapa, a White Martins liquefazia o gás natural e o enviava à GásLocal. Na terceira e última etapa, a GásLocal recebia o gás e o distribuía ao cliente final. A figura a seguir ilustra a dinâmica do Consórcio Gemini.

Figura 14 - Estrutura do Consórcio Gemini

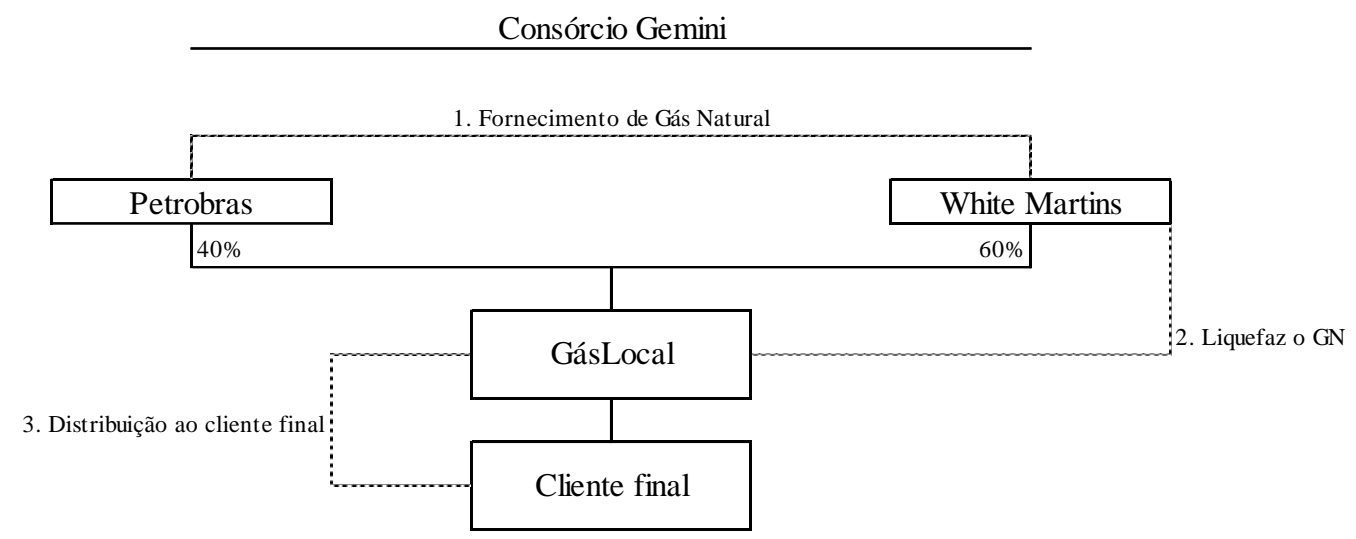

Fonte: elaboração do autor com base no volume 1 do anexo na página 7 do processo administrativo elaborado pela Superintendência Geral do CADE e parágrafo 65 do voto do relator, Paulo B. da Silveira.

\footnotetext{
${ }^{17}$ A constituição da joint venture GásLocal na estrutura do Consórcio Gemini foi submetida à aprovação do CADE. A aprovação foi feita mediante condições, consoante Ato de Concentração n. 08012.001015/2004-08.
} 
A estrutura do Consórcio Gemini inovou ao promover uma integração vertical. A Petrobras ao mesmo tempo passou a ser fornecedora e também, indiretamente, distribuidora local, uma vez que detinha participação societária na GásLocal.

Observou-se que a Petrobras, como monopolista na produção e distribuição por gasodutos de alta pressão, permaneceu fornecedora das demais distribuidoras e também passou a ser fornecedora para o consórcio de que participava.

Dois problemas decorrem da nova estrutura formada no Consórcio Gemini. Primeiro, a ausência de regulação de tal estrutura ainda inexistente no Brasil. Enquanto a White Martins recebe o gás diretamente da Petrobras para realizar a liquefação, os concorrentes recebem-no por meio das Companhias Distribuidoras Locais (CDL), geralmente empresas estatais ou privadas delegadas pelos Estados. Naturalmente, a inexistência de um intermediário reduz o custo do gás.

Segundo, no processo conhecido como city gate há despressurização do gás quando este sai do duto principal e é enviado para o duto local. Nesse momento há uma alteração regulatória, pois deixa de incidir regulação federal para incidir regulação estadual. Uma vez que não há CDL nem city gate, nota-se um vácuo regulatório, uma vez que, em tese, incidiria somente regulação federal.

A discussão foi de tal magnitude, que foi endereçada ao $\mathrm{STF}^{18}$. Em decisão liminar, o STF entendeu que a Petrobras não poderia fornecer o gás diretamente à White Martins; deveria fornecê-lo por meio da CDL da região de Paulínia, que era realizada pela Comgás. Apesar da decisão, as partes manifestaram impossibilidade de cumpri-la, em função de impedimentos operacionais.

\footnotetext{
${ }^{18} \mathrm{O}$ vácuo regulatório observado na operação da estrutura criada fez a discussão ser submetida ao STF por meio da Reclamação n. 4.210-3/SP.
} 
Segundo a SG do CADE (parágrafo 157, SEI n. 0202147), o vazio regulatório da nova estrutura vertical criada trouxe problemas concorrenciais. Primeiro, a GásLocal não pagava a distribuição regulada à distribuidora de gás canalizado (Comgás), assim havia redução de custo em relação aos concorrentes. Segundo, o custo do gás pago pelo Consórcio Gemini à Petrobras não seguia o preço público fixado, outrossim era sigiloso. $\mathrm{O}$ Consórcio Gemini sabia quanto os concorrentes pagavam pela aquisição do gás, todavia os concorrentes não sabiam quanto o Consórcio Gemini pagava pelo custo do gás.

Como consequência natural da nova estrutura vertical criada, quando $\mathrm{o}$ ato de concentração foi submetido ao $\mathrm{CADE}^{19}$ foram impostas restrições à sua aprovação. A aprovação ocorreu mediante publicidade do documento Anexo n. 6 do Acordo Operacional, das demonstrações financeiras da GásLocal e de contratos entre clientes e a GásLocal. A restrição tinha como objetivo dar aos concorrentes os meios necessários para identificar práticas potencialmente discriminatórias.

As restrições impostas pelo CADE à aprovação do ato foram objeto de questionamento judicial; na prática, nunca foram cumpridas. Os concorrentes permaneceram sem nenhum mecanismo de controle dos contratos firmados e de prática discriminatória.

Em função da falta de transparência e da avaliação da concorrente Comgás de que havia prática discriminatória, foi requerida de medida preventiva ${ }^{20}$, logo deferido pelo CADE em 2015, a fim de cessar tratamento discriminatório no fornecimento do gás.

A medida preventiva foi confirmada pelo Tribunal do CADE, suspensa pelo Poder Judiciário e finalmente confirmada pelo STJ. Em que

\footnotetext{
${ }^{19}$ A aprovação ocorreu mediante condições do Ato de Concentração n. 08012.001015/2004-08.

${ }^{20}$ Ciente da possibilidade de a criação da GásLocal trazer prejuízos ao ambiente concorrencial, a aprovação foi condicionada a uma série de medidas impostas pelo CADE, consoante SEI n. 0032321.
} 
pese a vigência, as representadas alegaram dificuldade no cumprimento por questões regulatórias, formais e estruturais.

Neste contexto surgiu a representação feita pela Companhia de Gás de São Paulo - Comgás em desfavor da Petróleo Brasileiro S.A., White Martins Gases Industriais Ltda. e GNL Gemini e Comercialização e Logística de Gás Ltda.

A Comgás noticiou ao CADE a prática de subsídio cruzado e a discriminação de preços no fornecimento do gás natural ao Consórcio Gemini, prejudicando os demais fornecedores presentes no mercado.

Considerando a avaliação feita pela Comgás no mercado e a falta de monitoramento em função do não cumprimento das restrições impostas no ato de concentração ${ }^{21}$ pelas representadas por decisão do Tribunal Regional Federal (TRF) da Primeira Região, a representante entendeu que havia conduta anticoncorrencial por parte das representadas.

Passada a análise do poder de mercado das representadas, o CADE identificou nítido poder econômico da Petrobras. A uma, em função da capacidade monopolista no mercado de transporte (mercado a montante). A duas, relevante participação no mercado de distribuição (mercado a jusante), bem como na oferta de produtos substitutos. Considerando a participação estatutária, comercial e estratégica da Petrobras no Consórcio Gemine, restou claro o poder de mercado.

No contexto em que o Consórcio Gemini estava inserido, o CADE identificou uma série de elementos propícios à prática anticoncorrencial, especialmente no que se refere a preços discriminatórios.

Primo, o Consórcio Gemini mostrou-se uma estrutura sui generis sob a óptica regulatória em função da integração vertical. Ao operar em um vácuo regulatório, não somente era menos regulado, como também tinha diferencial

\footnotetext{
${ }^{21}$ Ato de Concentração n. 08012011881/2007-41.
} 
competitivo na formação do preço em função de menos um intermediário na cadeia produtiva.

Secundo, quando ocorreu a aprovação do ato de concentração da formação do Consórcio Gemini, houve especial preocupação do CADE em função do fornecimento do gás diretamente da Petrobras à White Martins e ulteriormente à GásLocal, sociedades empresariais que não estavam sujeitas às exigências tarifárias e regulatórias.

Tal situação possibilitaria prática de preços artificialmente mais competitivos dentro da área de atuação da Comgás, assim gerando fechamento de mercado dentre outros danos. Em consequência disso, ao aprovar o ato de concentração, o CADE impôs restrições como condições à aprovação da formação do Consórcio Gemini. Nada obstante, tais restrições não foram cumpridas em função do questionamento judicial feito pelas representadas.

Diante de tal contexto, o CADE procurou identificar provas de tratamento diferenciado no fornecimento do gás natural ao Consórcio Gemini em detrimento dos demais concorrentes.

A primeira prova identificada consistiu na constatação do fornecimento do gás natural ao Consórcio Gemini a preços inferiores aos fornecidos aos concorrentes que atuam no mercado.

Neste ponto é importante compreender os contratos de fornecimento de gás. $\mathrm{O}$ fornecimento de gás frequentemente é contratado com cláusula take-or-pay e ship-or-pay. Isso significa que o comprador do gás paga por um volume mínimo entre sessenta por cento e oitenta por cento mesmo que não faça o uso do volume comprado.

Destarte, a Petrobras é dotada de um estoque de gás já pago e não utilizado pelos compradores. Tal sobra seria perdida pela Petrobras, não obstante ter sido paga pelo contratante. Assim, a sobra representa custo de 
oportunidade zero para a Petrobras, portanto gera incentivo para a comercialização subsidiada abaixo do mercado para o Consórcio Gemini.

A Petrobras se beneficiaria, uma vez que participava da estrutura societária da GásLocal. Assim, criou-se a oportunidade de um produto já pago que seria desperdiçado tornar-se insumo subsidiado para um consórcio de que a Petrobras auferia lucro no resultado final.

O Departamento de Estudos Econômicos (DEE) realizou estudo que identificou que o preço do gás fornecido ao Consórcio Gemini era inferior ao preço do gás fornecido à Comgás, considerando a Nova Política de Preços da Petrobras (NPP).

Identificou-se racionalidade no fornecimento do gás a preços subsidiados, uma vez que a Petrobras precisava destinar as sobras de gás em estoque e já pagas.

O CADE também identificou contratações atípicas de fornecimento de gás pela GásLocal em condições que seriam naturalmente mais competitivas do que o fornecimento pela Comgás. Tais contratações ocorreram em locais onde o fornecimento de GNC pela Comgás seria naturalmente mais competitivo que o fornecimento de GNL pela GásLocal.

A inobservância da lógica natural despertou indícios da prática de preços subsidiados no fornecimento de gás da Petrobras à White Martins e ulterior venda pela GásLocal. Tal fato foi identificado no contrato associativo entre a GásLocal e a Gasmig no município de Pouso Alegre (MG). Quando o contrato foi submetido ao $\mathrm{CADE}^{22}$, a contratante, indagada sobre a racionalidade da decisão informou o preço oferecido pela GásLocal pela venda do produto, valor inferior à tarifa regulada da Comgás.

Assim foi possível concluir que o gás natural era fornecido pela Petrobras ao Consórcio Gemini a preço inferior ao praticado no mercado.

\footnotetext{
22 Contrato associativo entre GásLocal e Gasmig objeto do Ato de Concentração n. $08700000137 / 2015-73$.
} 
A segunda prova identificada pelo CADE foram as cláusulas contratuais presentes no contrato de fornecimento de gás entre a Petrobras e o Consórcio Gemini. As cláusulas eram não somente atípicas como também nitidamente mais vantajosas em relação a outros contratos de fornecimento de gás pela Petrobras. Tais práticas se mostraram discriminatórias em relação aos concorrentes da GásLocal.

Dentre as principais cláusulas mais vantajosas e propícias a tratamento diferenciado capaz de gerar conduta anticoncorrencial, o CADE identificou: (I) duração do contrato, (II) reajuste com base no Índice Geral de Preços do Mercado (IGP-M) em vez de na cesta de óleo, (III) precificação em reais e não em dólares americanos e, por fim, (IV) a inexistência de cláusulas takeor-pay ou ship-or-pay.

A terceira prova identificada pelo CADE foi a prática de captura de clientes âncoras e fechamento do mercado por parte da GásLocal. Mister definir cliente âncora e sua importância no contexto da distribuição do gás.

Clientes âncoras são grandes empresas que demandam grande quantidade de produtos em escala tal, que dilui o custo fixo da chegada dos dutos nos locais de fornecimento do gás. Destarte, logo se nota que o cliente âncora traz externalidade positiva para a comunidade local, uma vez que viabiliza a instalação de dutos e fornecimento de gás a menor custo.

Considerando que a GásLocal celebrou contratos com clientes âncoras na região de fornecimento de gás da Comgás, tais contratações inviabilizaram a escala mínima necessária para justificar os investimentos em dutos, portanto as externalidades positivas propiciadas à comunidade local foram perdidas. Tais contratos só seriam possíveis por meio de práticas de preços subsidiados e mecanismos de fidelização de clientes âncoras.

A quarta prova identificada pelo CADE foi a ausência de racionalidade econômica que justificasse a prática discriminatória. Em que 
pesem os argumentos apresentados pelas representadas, não foi possível justificar de nenhuma forma as condutas discriminatórias.

Tanto na imposição das medidas preventivas em 2005 quanto na aprovação da formação do Consórcio Gemini, o CADE mostrou-se preocupado com as práticas discriminatórias que poderiam ocorrer em função do poder de mercado do Consórcio.

Foi neste contexto que o CADE condenou as representadas por práticas anticoncorrenciais no Consórcio Gemini por violação ao artigo 36, incisos I, II e IV, e parágrafo 3, incisos III, IV, V, VII, X, XI e XV, da Lei 12.529/2011.

As sanções impostas foram divididas em duas classificações, a saber: (I) estruturais e (II) pecuniárias.

As sanções estruturais consistiram, em primeiro lugar, na confirmação do inteiro teor da medida preventiva ${ }^{23}$ imposta pela Superintendência Geral (SG). Em síntese, visava a cessar o tratamento discriminatório no fornecimento do gás pela Petrobras ao Consórcio Gemini. Neste ponto o CADE almejou dar transparência e clareza no preço do fornecimento do gás natural pela Petrobras ao Consórcio Gemini.

Uma vez que as partes reiteradamente alegaram impossibilidade técnica do fornecimento de gás nas condições impostas pelo CADE, o Tribunal propôs como obrigação alternativa o fornecimento de gás da Petrobras ao Consórcio Gemini utilizando a Nova Política de Preços (NPP) da Petrobras.

Com isso o CADE almejou afastar qualquer prática de preços discriminatórios por parte da Petrobras em relação aos demais clientes diferentes do Consórcio Gemini. Qualquer desconto, benefício ou vantagem contratado entre Petrobras e Consórcio Gemini deveria ser estendido aos

\footnotetext{
${ }^{23}$ As medidas preventivas já tinham sido relacionadas no SEI n. 0032321. A sanção somente reiterou tais medidas.
} 
demais clientes no mercado. Suspendeu-se o Anexo n. 6 do contrato de fornecimento entre Petrobras e Consórcio Gemini.

Caso as representadas optassem pela obrigação alternativa, duas condições deveriam ser cumulativamente atendidas, a saber: (i) a aderência à obrigação alternativa deveria ser realizada por todas as empresas participantes do Consórcio Gemini, isto é, Petrobras, White Martins e GásLocal; (ii) que existisse auditoria independente aprovada pelo CADE e remunerada pela Petrobras e White Martins a fim de apresentar relatórios trimestrais que avaliem o cumprimento dos compromissos assumidos pelas representadas.

No campo das sanções pecuniárias, o CADE considerou como referência para estabelecer a multa o valor de $0,1 \%$ a $20 \%$ do valor do faturamento bruto da empresa ou conglomerado no exercício imediatamente anterior ao início do processo administrativo, limitado ao ramo de atividade empresarial em que ocorreu a infração, portanto seguiu os critérios previstos no artigo 37 da Lei 12.529/2011.

À Petrobras aplicou-se multa de R\$ 15.262.683,88; à White Martins aplicou-se multa de R \$ 6.214.166,05; e, por fim, à GásLocal aplicou-se multa de $\mathrm{R} \$$ 96.680,00. A dosimetria levou em consideração a reincidência, a situação econômica do infrator, os efeitos econômicos produzidos pela conduta, o grau de lesão à livre concorrência, a vantagem auferida, a boa-fé do infrator e, por fim, a gravidade da lesão. 


\section{Análise de Resultados}

O presente capítulo analisa as características das condutas verticais consideradas ilícitas à luz da interpretação dos conselheiros do CADE. É importante aclarar que foram estudados cinco julgados, que apresentavam casos distintos.

\subsection{Estatística Descritiva}

As condutadas unilaterais e verticais estudadas têm particularidades que as diferenciam. Em que pesem tais diferenças, a análise busca compreender características comuns às condutas ilícitas.

Antes da análise estatística dos dados coletados, buscou-se relacionar as características das condutas unilaterais e verticais e as das pessoas jurídicas representadas em cada caso que fizeram os conselheiros do CADE identificarem ilicitude concorrencial. Em síntese, apresentam-se os quadros a seguir.

Quadro 3 - Características da conduta da ACECOMVI

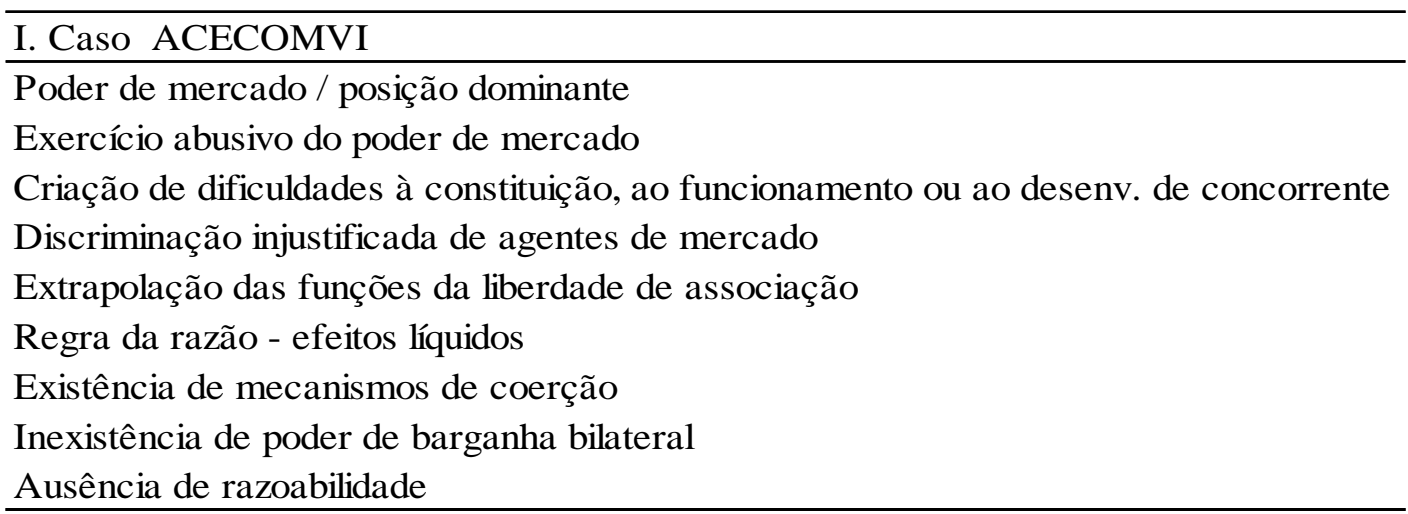

Fonte: elaboração do autor com base nos votos dos Conselheiros do CADE. 
Quadro 4 - Características da conduta da UNIMED Missões

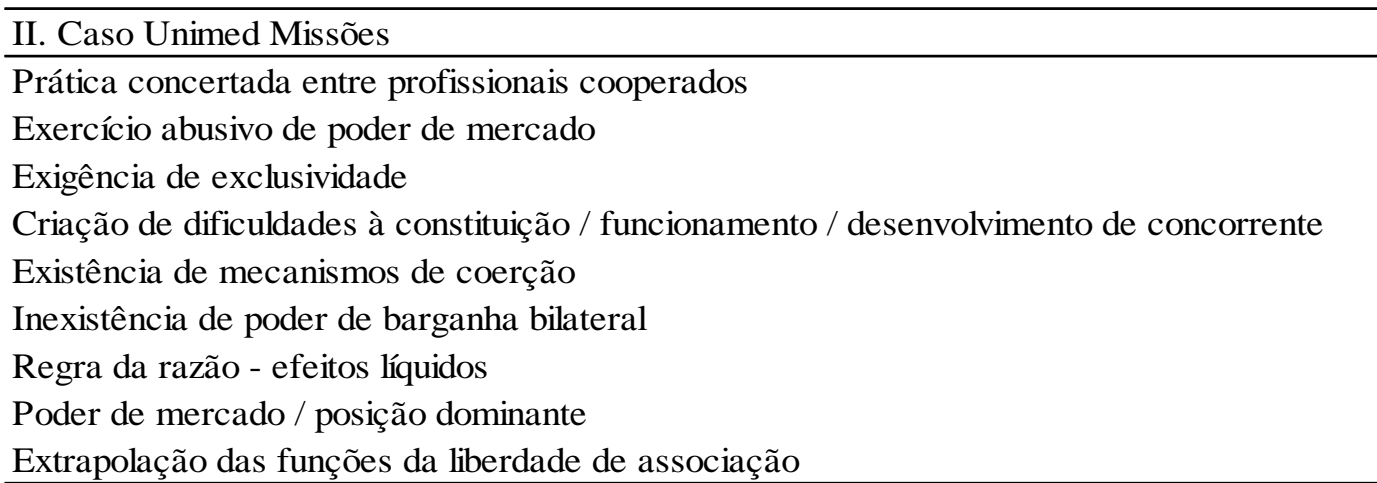

Fonte: elaboração do autor com base nos votos dos Conselheiros do CADE.

Quadro 5 - Características da conduta dos shopping centers

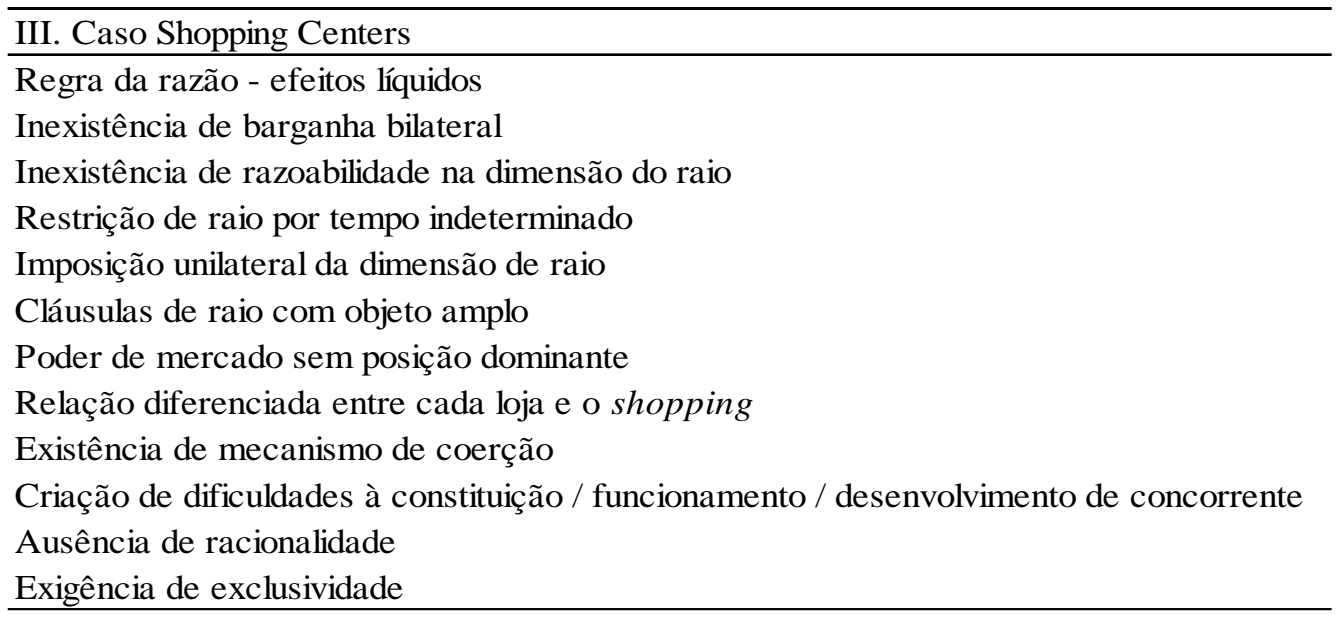

Fonte: elaboração do autor com base nos votos dos Conselheiros do CADE.

Quadro 6 - Características da conduta da TECON Rio Grande

\begin{tabular}{l}
\hline IV. Caso Tecon Rio Grande \\
Exercício abusivo do poder de mercado \\
Criação de dificuldades à constituição / funcionamento / desenvolvimento de concorrente \\
Capacidade de elevação de custo dos concorrentes
\end{tabular}

Fonte: elaboração do autor com base nos votos dos Conselheiros do CADE. 
Quadro 7 - Características da conduta no Consórcio Gemini

\section{Caso Consórcio Gemini}

Tratamento discriminatório de concorrentes

Fechamento de mercado

Ausência de racionalidade

Poder de mercado sem posição dominante

Ausência de regulação da atividade

Inobservância de restrições impostas pelo CADE

Conduta abusiva

Regra da razão - efeitos líquidos

Fonte: elaboração do autor com base nos votos dos conselheiros do CADE.

Passa-se à análise estatística das características das condutas das representadas. Buscou-se identificar as características mais frequentes nos votos dos conselheiros do CADE.

A análise utilizou o software IBM SPSS a fim de dar o tratamento estatístico adequado aos dados da pesquisa. O resultado do teste estatístico é apresentado na tabela a seguir.

Tabela 3 - Resultado do teste estatístico

\begin{tabular}{|c|c|c|c|c|c|}
\hline \multicolumn{6}{|c|}{ Características } \\
\hline & & Frequência & Percentual & $\begin{array}{l}\text { Percentagem } \\
\text { válida }\end{array}$ & $\begin{array}{r}\text { Percentagem } \\
\text { acumulativa }\end{array}$ \\
\hline \multirow[t]{22}{*}{ Válido } & Poder de mercado & 14 & \begin{tabular}{|c|}
9,8 \\
\end{tabular} & 9,8 & 9,8 \\
\hline & Exercício abusivo do poder de mercado & 6 & 4,2 & 4,2 & 14,0 \\
\hline & Regra da razão - efeitos líquidos & 16 & 11,2 & 11,2 & 25,2 \\
\hline & Inexistência de poder de barganha bilateral & 14 & 9,8 & 9,8 & 35,0 \\
\hline & Criação de dificuldades à constituição / funcionamento / desenvolvimento de concorrente & 15 & 10,5 & 10,5 & 45,5 \\
\hline & Discriminação injustificada de agentes de mercado & 12 & 8,4 & 8,4 & 53,8 \\
\hline & Extrapolação das funções da liberdade de associação & 6 & 4,2 & 4,2 & 58,0 \\
\hline & Existência de mecanismos de coerção & 12 & 8,4 & 8,4 & 66,4 \\
\hline & Prática concertada entre profissionais cooperados & 1 &, 7 &, 7 & 67,1 \\
\hline & Exigência de exclusividade & 13 & 9,1 & 9,1 & 76,2 \\
\hline & Ausência de racionalidade & 11 & 7,7 & 7,7 & 83,9 \\
\hline & Capacidade de elevação de custo dos concorrentes & 1 &, 7 &, 7 & 84,6 \\
\hline & Inexistência de razoabilidade na dimensão do raio & 2 & 1,4 & 1,4 & 86,0 \\
\hline & Restrição de raio por tempo indeterminado & 5 & 3,5 & 3,5 & 89,5 \\
\hline & Imposição unilateral da dimensão de raio & 2 & 1,4 & 1,4 & 90,9 \\
\hline & Cláusulas de raio com objeto amplo & 3 & 2,1 & 2,1 & 93,0 \\
\hline & Relação diferenciada entre cada loja e o shopping & 1 &, 7 &, 7 & 93,7 \\
\hline & Fechamento de mercado & 5 & 3,5 & 3,5 & 97,2 \\
\hline & Ausência de regulação da atividade & 1 &, 7 &, 7 & 97,9 \\
\hline & Inobservância de restrições impostas pelo CADE & 2 & 1,4 & 1,4 & 99,3 \\
\hline & Ausência de razoabilidade & 1 &, 7 &, 7 & 100,0 \\
\hline & Total & 143 & 100,0 & 100,0 & \\
\hline $\begin{array}{l}\text { Qui-quadrado } \\
\text { df }\end{array}$ & $\begin{array}{l}91,818^{\mathrm{a}} \\
20\end{array}$ & & & & \\
\hline Significância Assintótica &, 000 & & & & \\
\hline
\end{tabular}

Fonte: elaboração do autor com base nos testes utilizando software IBM SPSS.

A análise por meio de estatística descritiva pesquisou a frequência das características das condutas consideradas ilícitas pelo CADE. As sete 
características mais frequentes mencionadas pelos conselheiros foram: (I) existência de poder de mercado pelo agente; (II) efeitos líquidos negativos analisados à luz da regra da razão; (III) criação de alguma espécie de dificuldade à constituição ao funcionamento ou ao desenvolvimento de concorrentes; (IV) inexistência de poder de barganha bilateral; (V) exigência de exclusividade; (VI) existência de algum mecanismo de coerção por parte das representadas; e, por fim, (VII) discriminação injustificada de agentes de mercado.

A análise das condutas unilaterais e verticais à luz da regra da razão esteve presente expressamente em quatro dos cinco casos analisados. No caso em que não foi citada expressamente, esteve presente nos fundamentos da análise do Tribunal.

É inequívoco o entendimento da autoridade antitruste brasileira quanto à avaliação das condutas unilaterais e verticais à luz da regra da razão. Significa asseverar que até o presente momento, exceto o tratamento dado ao caso SKF, a autoridade antitruste entende que não há ilícitos per se quando se avalia uma conduta unilateral e vertical.

O tratamento dado ao caso SKF é uma exceção à regra geral, a qual confirma a regra da avaliação dos ilícitos unilaterais e verticais pela regra da razão. A exceção observada consta somente em um caso, portanto, por ora, não há que se falar em tendência a partir de uma única decisão.

Ademais, no caso SKF, o conceito de ilícito per se não foi tomado de forma absoluta, todavia resultou de inversão do ônus da prova. Houve significativa divergência dos conselheiros nos votos apresentados em tal caso.

As condutas verticais devem ser analisadas sopesando os efeitos negativos e positivos. É importante realizar análise casuística sem possibilidade de ex ante determinar licitude ou ilicitude. Cada caso apresenta 
suas idiossincrasias, que merecem estudo detalhado a fim de compreender se a conduta é ilícita.

No caso ACECOMVI, de um lado, a liberdade de associação e os benefícios naturais conquistados pelos partícipes da associação e pelos clientes. De outro, os efeitos anticoncorrenciais das condutas da associação. Sopesados tais efeitos, a conduta apresentou mais efeitos negativos que positivos, portanto foi caracterizado o ilícito concorrencial.

No caso UNIMED Missões, a reunião dos médicos em cooperativas traz benefícios tanto para os médicos quanto para os pacientes. Não obstante, a conduta da representada trouxe mais efeitos negativos que positivos ao bem-estar dos pacientes. Foi neste sentido considerada conduta ilícita.

O caso das cláusulas de raio dos shopping centers, segundo relato de um dos conselheiros do CADE, mostrou-se um dos mais difíceis e desafiadores enfrentados pelos Tribunal. De um lado, efeitos positivos como a tutela do investimento dos shopping centers, a proteção contra desvios de faturamento para outras lojas, a tutela do tenant mix, dentre muitos outros pontos arguidos pelos shopping centers.

Em que pese a legitimidade dos argumentos que tutelam as cláusulas de raio, a prática foi considerada ilícita no caso julgado, uma vez que apresentou mais efeitos negativos que positivos ao ambiente concorrencial.

No caso Consórcio Gemini, as representadas apresentaram uma série de argumentos que fundamentavam a estrutura do Consórcio. O CADE conseguiu identificar efeitos positivos na estrutura do Consórcio, contudo os efeitos negativos superaram aqueles. A discriminação dos concorrentes, o fechamento do mercado e a ausência de racionalidade na conduta, dentre outras questões, fizeram o CADE considerar a conduta ilícita à luz da regra da razão.

A existência de poder de mercado por parte do agente esteve presente em todos os votos analisados. Trata-se de uma característica pressuposta, 
uma premissa para a conduta ser considerada ilícita. Neste ponto, duas observações importantes quanto ao tema.

Primeira, o simples fato de um agente ter poder de mercado não faz de nenhuma conduta unilateral e vertical um ilícito concorrencial. A conduta precisa ser exercida por um agente com poder de mercado e também precisa gerar efeitos líquidos negativos para ser um ilícito.

Segunda, não se pode confundir poder de mercado com participação de mercado. Por diversas vezes os conselheiros consideraram poder de mercado nos casos em que as representadas tinham menos de vinte por cento de market share.

Isso mostra que a lei faz uma presunção iuris tantum (presunção relativa) de que participações de pelo menos vinte por cento confeririam poder de mercado ao agente. Apesar da presunção, foi observado que tanto nos julgados analisados quanto nas citações de decisões pretéritas o CADE pode considerar agentes que tenham menos de vinte por cento como detentores de poder de mercado.

Nos casos ACECOMVI e UNIMED Missões, a participação de mercado excedia consideravelmente a presunção legal, portanto não restou nenhuma dificuldade para a identificação da característica. O caso dos shopping centers, por sua vez, não somente identificou poder de mercado para detentores de menos de vinte por cento do mercado como citou diversos precedentes do CADE no mesmo sentido.

Observou-se, nos casos analisados, que as representadas tiveram a intenção de criar alguma dificuldade à constituição ou ao funcionamento ou ao desenvolvimento de empresa concorrente.

Em que pese o entendimento de que as estratégias empresariais para conquista de mercado tais como diferenciação, políticas agressivas de conquista de clientes, ganho de eficiência sejam condutas lícitas, observouse a criação de dificuldade aos concorrentes utilizando o poder de mercado. 
$\mathrm{O}$ uso do poder de mercado para criar qualquer dificuldade aos concorrentes acarreta fechamento de mercado e prejuízo ao bem-estar dos consumidores.

Tais dificuldades são indesejadas e combatidas pelas autoridades antitruste em vários países. No Brasil, a autoridade antitruste busca compreender se a conduta tem por fim reduzir a concorrência ou é um efeito de alguma outra circunstância.

Observada a criação de alguma dificuldade para empresas concorrentes, a autoridade concorrencial pode impor medidas a fim de retirar os óbices à concorrência de demais empresas.

Em que pesem tais possibilidades, quando a criação de dificuldade para empresas concorrentes competirem se mostra como objeto da conduta da empresa detentora de poder de mercado, a conduta é ilícita.

Nos casos pesquisados, a autoridade antitruste entendeu que a criação de dificuldades aos concorrentes teve animus de reduzir a concorrência. As representadas tiveram intenção de criar barreiras aos concorrentes e prejudicar o ambiente concorrencial, portanto caracterizou-se ilícito concorrencial.

No caso ACECOMVI, a proibição de os guias frequentarem shopping centers não associados claramente tinha por fim restringir a concorrência e prejudicar os não associados.

A UNIMED Missões, ao vedar o credenciamento dos médicos nas seguradoras concorrentes, promoveu o fechamento do mercado e a redução de médicos credenciados por seguradoras de saúde na região. Não só impedia a entrada de concorrentes, como também restringia as opções dos pacientes.

Os shopping centers, ao imporem cláusulas de raio, tanto criaram dificuldade à livre-iniciativa dos lojistas como também promoveram fechamento do mercado. Ao impedirem que um lojista estabelecesse 
comércio em outros shopping centers, impediram que concorrentes tivessem acesso ao insumo principal do negócio.

No caso TECON Rio Grande, a cobrança pela armazenagem por período de quinze dias, ainda que a carga fosse retirada do pátio em até quarenta e oito horas, desestimulou a transferência para Estações Aduaneiras Interiores, uma vez que a armazenagem já estava paga por quinze dias.

A inexistência de poder de barganha bilateral entre os envolvidos nas condutas verticais foi identificada como uma característica do ilícito concorrencial.

Em situações em que haja equilíbrio de forças entre as partes, dificilmente se observarão abuso do poder de mercado e condutas ilícitas à luz do direito concorrencial. Tal situação pode não ocorrer quando há desequilíbrio de forças.

Quando um agente de mercado detém mais força que outro tende a impor a sua política. Nesses casos é mais frequente a possibilidade de condutas ilícitas.

$\mathrm{O}$ agente com menos força tende a se submeter ao mais forte, não obstante a conduta imposta seja ilícita. Foi o caso dos guias de turismo em relação à conduta da ACECOMVI, dos médicos em relação à UNIMED Missões e das lojas não âncoras em relação aos shopping centers.

A grande dificuldade mencionada pelos conselheiros do CADE foi a identificação do limite entre a autonomia privada e a ocorrência de ilícito concorrencial. Conquanto a máxima pacta sunt servanda deva ser protegida, a tutela do ambiente concorrencial se sobrepõe em alguns casos em função da proteção da coletividade.

Os conselheiros do CADE identificaram a exigência de exclusividade como característica de conduta ilícita à luz da lei concorrencial. É necessário aclarar que a exigência de exclusividade, assim como demais condutas verticais, não são ilícitas per se. 
Em alguns casos, explorados no referencial teórico da presente pesquisa, admite-se exigência de exclusividade sem que haja ilício concorrencial. Nos casos analisados, observou-se ausência de qualquer razoabilidade capaz de justificar a exigência de exclusividade.

No caso ACECOMVI, a exclusividade exigida dos guias de turismo de compra para frequentar somente shopping centers associados careceu de justificativa. Tinha por fim somente criar barreiras à ida dos consumidores a outros shopping centers atacadistas.

A UNIMED Missões, ao exigir que os médicos cooperados não realizassem credenciamentos em concorrentes, promoveu duplo prejuízo ao ambiente concorrencial. A uma, dificultou que os clientes dos planos de saúde contratassem outros planos de saúde, assim restringiram a oferta aos consumidores. A duas, criaram barreiras a novos entrantes, uma vez que, sem o insumo fundamental (os médicos), foi inviável novos concorrentes entrarem no mercado.

Os shopping centers, por sua vez, também incorreram em ilícito concorrencial ao impor cláusulas de raio nos contratos. A cláusula de raio tem como principal efeito a exigência de exclusividade do lojista em relação ao shopping center.

Em que pese a conduta da TECON Rio Grande não ter sido exigência de exclusividade, o ilícito concorrencial teve como gênese uma exclusividade. $\mathrm{O}$ armador, ao contratar o operador portuário, confere exclusividade no serviço de descarga e movimentação da carga no pátio. Com tal monopólio, o operador portuário foi capaz de exercer ilícito concorrencial ao cobrar pelo armazenamento por período de quinze dias, não obstante a carga ser retirada do pátio em menos de quarenta e oito horas.

Os conselheiros do CADE identificaram que as condutas verticais ilícitas tinham algum mecanismo de coerção por parte do agente que tinha maior força. 
A ACECOMVI exercia coerção em relação aos guias, retendo ou não pagando comissões, por vezes realizando descredenciamento. A UNIMED Missões tinha o poder de descredenciar médicos que aceitassem convênio com concorrentes. Os shopping centers exerciam coerção em relação aos lojistas não âncoras por meio de multas ou mesmo denúncia contratual.

Observa-se em comum algum mecanismo existente para fazer valer a imposição da parte mais forte na relação comercial, a fim de produzir efeitos prejudiciais ao ambiente concorrencial. Tal mecanismo caracterizou a ilicitude da conduta das representadas.

Por fim, os conselheiros identificaram como característica de conduta ilícita a discriminação injustificada de agentes de mercado. Em condições normais de mercado há liberdade dos agentes para contratar nas relações comerciais.

A discriminação na contratação é conduta estranha ao ambiente concorrencial, merecedora de análise apurada a fim de identificar alguma justificativa razoável para a recusa.

No caso ACECOMVI, a recusa de os guias frequentarem os shopping centers não associados careceu de fundamento racional. No caso UNIMED Missões, observou-se a recusa injustificada de os médicos cooperados contratarem com seguradoras de saúde ou demais cooperativas.

No caso Shopping Centers, em que pese a justificativa da presença da cláusula de raio para que os lojistas não contratassem com outros shopping centers, a imposição da restrição de raio mostrou-se injustificada. No caso Consórcio Gemini, a discriminação na comercialização do preço do gás mostrou-se desprovida de fundamento, salvo subsídio ilícito no preço do insumo. 


\subsection{Teste de Hipóteses}

Analisadas as características das condutas por meio de estatística descritiva, passa-se à análise das características por meio do teste estatístico Chi-Quadrado $\left(\mathrm{X}^{2}\right)$.

A hipótese nula $\left(\mathrm{H}_{0}\right)$ considera que as proporções das características das condutas concorrenciais ilícitas são iguais. Isso significa que a hipótese nula pressupõe que $H_{0}=P_{1}=P_{2} \ldots=P_{21}$. A hipótese alternativa $\left(H_{a}\right)$ significa que pelo menos uma das proporções excede $1 / 21$, assim existe uma tendência nas respostas dos entrevistados.

Se a hipótese nula é verdadeira $\mathrm{H}_{0}=\mathrm{P}_{1}=\mathrm{P}_{2} \ldots=\mathrm{P}_{21}$, o valor esperado de cada característica será $\mathrm{E}\left(\mathrm{n}_{1}\right)=\mathrm{np}=(\mathrm{n}) 1 / 21$, assim como outra característica teria valor esperado $\mathrm{E}\left(\mathrm{n}_{2}\right)=\mathrm{np}=(\mathrm{n}) 1 / 21$ e assim por diante até a vigésima primeira característica identificada.

O teste com distribuição Chi-Quadrado $\left(X^{2}\right)$ mede o grau de discordância entre os dados de uma hipótese nula $\left(\mathrm{H}_{0}\right)$. Quanto mais distante cada característica de conduta ilícita $\left(\mathrm{n}_{1}, \mathrm{n}_{2}, \mathrm{n}_{3} \ldots \mathrm{n}_{21}\right)$ estiver do valor esperado $(\mathrm{np})$, maior será o $\mathrm{X}^{2}$ e maior a chance de a hipótese nula $\left(\mathrm{h}_{0}\right)$ ser negada.

O teste Chi-Quadrado $\left(\mathrm{X}^{2}\right)$ considerando o valor vinte como grau de liberdade (degree of freedom - df) gerou resultado de 91,81. O resultado do teste está localizado na zona de rejeição da hipótese nula.

Corrobora a rejeição da hipótese nula a significância assintótica observada com valor aproximadamente zero. A significância assintótica, mais conhecida como $p$-value, identifica a possibilidade de negar a hipótese nula sendo tal hipótese verdadeira. Indica a probabilidade de erro na rejeição de uma hipótese nula.

$\mathrm{O} p$-value zero indica que a probabilidade de erro ao rejeitar a hipótese nula é aproximadamente zero. Considerando o grau de significância usado na pesquisa de um por cento, pode-se rejeitar a hipótese nula. 
Assim, ao rejeitar a hipótese nula, há noventa e nove por cento de certeza estatística de que as proporções das características dos ilícitos concorrenciais nas condutas verticais analisadas são distintas. Admite-se erro de um por cento em tal afirmação.

A análise estatística identifica que há características mais presentes nas condutas verticais consideradas ilícitas. As sete características citadas no início do presente capítulo, sendo o poder de mercado um pressuposto, são as que mais caracterizam a ilicitude.

Em que pese tal certeza estatística, não se pode olvidar que as condutas verticais não são ilícitas per se. Tanto a doutrina quanto a pesquisa realizada identificam condutas verticais como condutas que devem ser analisadas à luz dos efeitos líquidos produzidos.

A característica mais frequente entre todas as pesquisadas é a avaliação das condutas por efeitos líquidos segundo a regra da razão. Isto posto, não se pode afirmar que, uma vez presentes as principais características identificadas neste estudo como ilícitos concorrenciais, a conduta vertical seria ilícita.

Uma vez presentes tais características, há indícios de que a conduta tenha boa probabilidade de ser ilícita, contudo deve sempre ser analisada à luz da regra da razão. É fundamental compreender os efeitos líquidos produzidos. Caso os efeitos positivos superem os negativos e não haja prejuízo ao ambiente concorrencial, a conduta deve ser considerada lícita. 


\section{Conclusão}

O objetivo do presente estudo foi identificar as principais características das condutas verticais e unilaterais consideradas ilícitas à luz dos julgados dos conselheiros do CADE, fundamentados na legislação antitruste nacional.

A doutrina e o estudo de cinco julgados, nos anos de 2016 e 2017, de condutas unilaterais e verticais consideradas ilícitas identificou sete características, a saber: (I) exercício por agente com poder de mercado, (II) efeitos líquidos negativos analisados à luz da regra da razão, (III) intenção do agente em criar dificuldade à constituição, ao funcionamento ou ao desenvolvimento de concorrentes, (IV) existência de relação comercial em que inexista poder de barganha bilateral, (V) exigência de exclusividade pelo detentor de poder na relação comercial, (VI) existência de mecanismos de coerção da parte mais forte na relação comercial e, por fim, (VII) discriminação injustificada de agentes de mercado.

A compreensão de uma conduta vertical e unilateral deve ser realizada à luz da regra da razão. Devem ser cotejados efeitos positivos e negativos da conduta. Uma vez que os efeitos positivos superem os efeitos negativos, conclui-se que houve melhoria no bem-estar dos consumidores. Nesses casos não há que falar em ilicitude concorrencial.

Dentre as conclusões do presente estudo, a compreensão da conduta à luz dos efeitos líquidos é inequivocamente a mais relevante. Tanto a doutrina quanto os votos dos conselheiros do $\mathrm{CADE}$, exceto no caso de fixação de preço mínimo pela SKF, anterior ao período da pesquisa, asseveram que condutas unilaterais e verticais não podem ser consideradas ilícita per se.

O poder de mercado consiste em uma característica do agente que realiza a conduta. É um pressuposto para a existência de um ilícito antitruste. Inexistente o poder de mercado, a conduta não é capaz de produzir efeitos relevantes no ambiente concorrencial, daí a impossibilidade de ser 
considerada conduta ilícita. Toma-se, portanto, o poder de mercado como premissa.

As políticas e iniciativas que almejam conquista de mercado e ganho de eficiências são naturais e esperadas em uma economia de mercado. Segundo a doutrina e os votos dos conselheiros do CADE, a ilicitude ocorre quando um agente usa o poder de mercado para realizar conduta que prejudique o ambiente concorrencial.

Neste ponto, é fundamental observar que o ilícito é caracterizado pela efetiva possibilidade de ocorrência de dano à concorrência independente de culpa do agente.

A desigualdade de forças entre agentes de mercado, frequentemente citada pelos conselheiros como inexistência de poder de barganha bilateral, foi uma característica identificada nas condutas consideradas ilícitas. Não significa asseverar que toda relação comercial desigual traga consigo uma conduta unilateral e vertical ilícita, todavia há maior probabilidade de tais relações terem alguma ilicitude. Isso ocorre em função de a parte mais fraca estar sujeita às imposições da parte mais forte na relação comercial.

Os julgados estudados identificaram que condutas verticais que exigiram exclusividade de um agente tinham a capacidade de reduzir o ambiente concorrencial e com isso prejudicar o bem-estar dos consumidores.

Assim como as demais condutas verticais, a exigência de exclusividade foi analisada à luz dos efeitos líquidos segundo a regra da razão. Nesta análise faltaram fundamentos que justificassem a prática de exclusividade. Nos julgados ficou claro que a exigência de exclusividade imposta pelo agente com maior poder de barganha tinha por fim prejudicar o ambiente concorrencial, portanto foi considerada conduta ilícita.

Por fim, duas características de condutas verticais e unilaterais ilícitas foram identificadas nos votos dos conselheiros do CADE: a existência de 
algum mecanismo de coerção por parte do agente com maior poder de mercado e a discriminação injustificada de agentes de mercado.

Os mecanismos de coerção funcionam como meio para dar eficácia à conduta imposta pelo agente com maior poder de mercado. Mecanismos como multas, descredenciamento, denúncia contratual, dentre outros, foram observados nos casos julgados.

A discriminação de um agente em uma economia de mercado causa natural estranheza. Em condições normais, não fornecer um insumo ou fornecê-lo por valor subsidiado a um agente deve apresentar alguma justificativa razoável.

Nos casos em análise, a discriminação injustificada de agentes de mercado mostrou-se característica de conduta ilícita. Deixar de fornecer ou fornecer insumo a preço subsidiado sem justificativa foi considerada conduta ilícita pelos conselheiros do CADE.

A pesquisa na doutrina e nos julgados identificou características de condutas verticais e unilaterais ilícitas. Em que pese a identificação, a existência de tais condutas não faz da conduta um ilícito concorrencial. As condutas devem sempre ser analisadas pelos seus efeitos líquidos à luz da regra da razão.

Destarte, foi possível concluir que a caracterização de uma conduta vertical e unilateral ilícita deve ser feita à luz de uma característica pressuposta, qual seja, o poder de mercado; uma característica central e características satélites, a saber: respectivamente, os efeitos líquidos negativos analisados à luz da regra da razão e as espécies de condutas identificadas pelos julgados.

Partindo do poder de mercado, característica pressuposta, quando há o encontro de uma ou mais características satélites com a característica central observa-se a conduta ilícita. 
Figura 15 - Classificação das características das condutas verticais

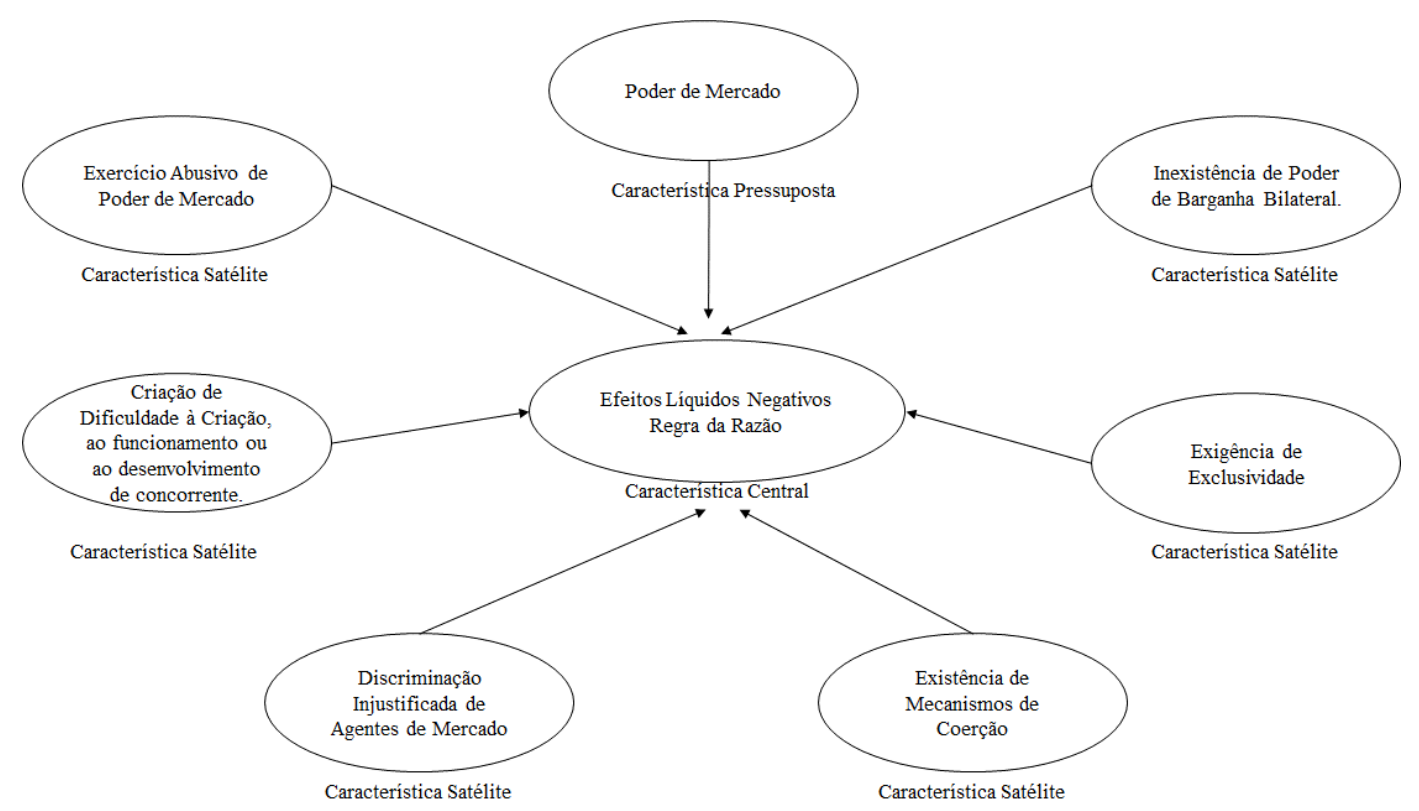

Fonte: elaboração do autor.

A pesquisa realizada corrobora o entendimento doutrinário e os votos presentes nos julgados recentes do CADE. Uma conduta vertical e unilateral por si só não é um ilícito concorrencial. É necessário que a conduta seja entendida à luz da regra da razão a fim de compreender os efeitos líquidos no mercado. Nos casos em que exista poder de mercado e a conduta traga como consequência efeitos líquidos negativos é caracterizado o ilícito concorrencial. 


\section{Sugestão para Pesquisas Futuras}

$\mathrm{O}$ estudo da conduta denominada exigência de exclusividade tem como busílis a preocupação com a dimensão do fechamento de mercado em decorrência da exclusividade.

Neste ponto nem a doutrina nem os votos dos conselheiros do CADE não identificam um patamar de fechamento de mercado considerado tolerável e incapaz de produzir efeitos negativos no mercado.

O fechamento de mercado considerado seguro, também denominado na doutrina internacional de safe harbor, permanece desconhecido pelos agentes no Brasil.

Como uma das principais preocupações das autoridades antitruste no mundo é promover comunicação transparente com o mercado e não dar sinais equivocados, também o CADE atua dessa mesma forma.

Destarte, uma pesquisa sobre o patamar de fechamento de mercado considerado aceitável quando existe conduta de exclusividade seria salutar tanto para o mercado quanto para o CADE.

A conduta classificada como abuso de posição dominante admite várias práticas na seara das condutas. Uma pesquisa que tenha como finalidade identificar ou classificar condutas que promovam fechamento de mercado como, verbi gratia, concessão de benefícios seria muito útil tanto para a autoridade antitruste quanto para o mercado.

Os agentes de mercado buscam, cada vez mais, novos meios para expandir suas operações. Dentre tais meios é possível observar algumas condutas unilaterais e verticais. Uma pesquisa sobre abuso de posição dominante por meio de condutas contemporâneas, especialmente as que promovem fechamento de mercado, seria enriquecedora para a doutrina, para os agentes e para a autoridade concorrencial. 
Um dos principais temas que geram divergência entre os conselheiros do CADE é a multa aplicada nas condutas unilaterais e verticais consideradas ilícitas. Há amplo debate sobre o tema e, especialmente no caso ACECOMVI, a discussão sobre o valor da multa tomou mais tempo e debate dos conselheiros que o julgamento da conduta.

A discussão do valor da multa está sempre presente nos debates entre os conselheiros do CADE. Uns defendem o caráter dissuasório, outros entendem mais importante a vinculação entre a multa e a vantagem auferida. A redação da legislação dá amplo espaço para debate e interpretações.

Em meio a tal polêmica, seria salutar uma pesquisa sobre algum método objetivo para cálculo de multas nos casos de condutas unilaterais e verticais. Alguns conselheiros já citam a necessidade de um Guia de Dosimetria ou Guia de Sanções Pecuniárias a fim de dar previsibilidade aos agentes econômicos.

Se alguns criticam a possibilidade de previsão da multa como critério decisório do agente para exercer a conduta, há bons argumentos contra tal crítica.

Primeiro, há grande discussão na doutrina econômica se os agentes tomam todas as decisões de forma racional. Os últimos ganhadores do Prêmio Nobel de Economia apresentaram estudos que afastam o paradigma da total racionalidade dos agentes ${ }^{24}$.

Segundo, a previsibilidade de sanção é uma realidade no Estado Democrático de Direito em diversas áreas. Na esfera cível, uma cláusula penal prefixa perdas e danos das partes. Na área penal, o indivíduo sabe, antes de cometer o crime, a qual pena estará sujeito. Nesse sentido, não há óbice algum para que seja conhecida a pena de uma conduta concorrencial ilícita antes de o agente cometê-la.

\footnotetext{
${ }^{24}$ Destacam-se nos estudos comportamentais o psicólogo Daniel Kahneman e o economista Richard Thaler, ambos ganhadores do Prêmio Nobel de Economia.
} 
Uma pesquisa sobre o mecanismo de interação entre autoridades envolvidas em investigações, análises e atuação nos casos de condutas tanto verticais quanto horizontais, especialmente as que envolvem indenizações, seria importante para o melhor funcionamento do sistema de defesa antitruste.

Salvo no caso Rio Madeira, em que se observou amplo processo de cooperação entre os agentes, ainda não há estudos sobre mecanismos eficientes de cooperação. Os casos que tiveram como gênese os programas de colaboração premiada da Operação Lava Jato mostram a importância de mecanismos de cooperação entre autoridades.

Em que pese o presente estudo ser dedicado às condutas unilaterais e verticais ilícitas, é difícil estudar o tema sem explorar as condutas horizontais. Dessarte, o exame de algumas condutas horizontais mostrou a importância de algumas pesquisas futuras, que são sugeridas a seguir.

$\mathrm{Na}$ seara dos acordos cooperativos entre concorrentes diversos da prática de cartel, seria importante alguma pesquisa sobre referências e parâmetros sobre tais acordos.

Um guia de orientação que, em conjunto com a Resolução CADE n. 20, regulasse os acordos cooperativos entre concorrentes diversos de cartéis seria muito importante para o mercado. A experiência internacional mostra que autoridades antitruste estrangeiras já se dedicaram ao tema como, verbi gratia, o Antitrust Guideline for Collaborations Among Competitors nos EUA e o Tratado sobre Funcionamento da União Europeia a Acordos de Cooperação Horizontal no mercado Europeu.

Na seara das condutas predatórias, observou-se dificuldade de aplicar sanções, uma vez que a condenação requer sejam vencidas muitas etapas até que se conclua pela prática predatória.

A inexistência de qualquer negativa nas fases faz que o processo seja arquivado. Nesse sentido, uma pesquisa futura sobre formas mais flexíveis 
de avaliar condutas predatórias seria de grande valia, pois as autoridades julgadoras tendem a ter postura mais conservadora ao julgar tais condutas. 


\section{Bibliografia}

ANDERSON, David R.; SWEENEY, Dennis J.; WILLIAMS, Thomas A. Estatística aplicada à administração e economia. 2.ed. São Paulo: Pioneira Thomson Learning, 2005. 642 p.

ASSOCIAÇÃO BRASILEIRA DE NORMAS TÉCNICAS. NBR 6023: informação e documentação: referências: elaboração. Rio de Janeiro, 2002.

ASSOCIAÇÃO BRASILEIRA DE NORMAS TÉCNICAS. NBR 10520: informação e documentação: citações em documentos: apresentação. Rio de Janeiro, 2002.

BORBA, José Edwaldo Tavares. Direito Societário. 14.ed. São Paulo: Atlas, 2015. 550 p.

BRASIL. Agência Nacional de Saúde Suplementar. Resolução Normativa n. 175 de 22 de set. de 2008. Acrescenta o item 2 ao Anexo I e o item 3 ao Anexo IV da Resolução Normativa n. 85, de 7 de dezembro de 2004, acrescenta o inciso $\mathrm{V}$ ao art. 25 da mesma Resolução e dá outras providências. Diário Oficial da República Federativa do Brasil, Brasília, DF, 23 set. 2008. Disponível em: <http://www.ans.gov.br/component/legislacao /?view=legislacao\&task=TextoLei\&format=raw\&id=MTMzMA==>.

Acesso em: 12 dez. 2017.

BRASIL. Conselho Administrativo de Defesa Econômica. Representada SKF do Brasil Ltda. Processo Administrativo n. 08012.001271/2001-44, Relator Conselheiro Vinícius Marques de Carvalho, Brasília, 19 jan. 2010.

BRASIL. Conselho Administrativo de Defesa Econômica. Representada Bematech S.A. e Fagundez Distribuição Ltda. Processo Administrativo n. 08012.010829/2011-54, Relator Conselheiro Gilvandro Vasconcelos Coelho de Araújo, Brasília, 05 set. 2014.

BRASIL. Conselho Administrativo de Defesa Econômica. Representada Kibon - Kraft Suchard Brasil S.A. Processo Administrativo n. 148/1992, Relator Conselheiro Leônidas Rangel Xausa, Brasília, 5 nov. 1997.

BRASIL. Conselho Administrativo de Defesa Econômica. Representada Associação dos Centros Comercias Atacadistas de Santa Catarina (ACECOMVI). Processo Administrativo n. 08012.007155/2008-13, Relatora Conselheira Cristiane Alkmin Junqueira Schmidt, Brasília, 13 dez. 2017. 
BRASIL. Conselho Administrativo de Defesa Econômica. Representada Unimed Missões RS. Processo Administrativo n. 08700.009890/2014-43, Relator Conselheiro Márcio de Oliveira Júnior, Brasília, 30 mar. 2016.

BRASIL. Conselho Administrativo de Defesa Econômica. Representada Administradora Gaúcha de Shopping Center S/A e outros. Processo Administrativo n. 08012.012740/2007-46, Relator Conselheiro Márcio de Oliveira Júnior, Brasília, 22 jun. 2016.

BRASIL. Conselho Administrativo de Defesa Econômica. Representados Multi Armazéns Ltda. e Transportadora Simas Ltda. Processo Administrativo n. 08012.005422/2003-03, Relator Conselheiro Gilvandro Vasconcelos Coelho de Araújo, Brasília, 04 fev. 2016.

BRASIL. Conselho Administrativo de Defesa Econômica. Representados Petróleo Brasileiro S.A., White Martins Gases Industriais Ltda. e NL Gemini e Comercialização e Logística de Gás Ltda. Processo Administrativo n. 08012.011881/2007-41, Relator Conselheiro Paulo Burnier da Silveira, Brasília, 7 dez. 2016.

BRASIL. Conselho Administrativo de Defesa Econômica. Resolução n. 16, de 01 de set. de 2016. Alteração do artigo $7^{\circ}$ da Resolução CADE $n^{\circ} 2 / 2012$ e estabelecimento do prazo de (30) trinta dias para análise, pela Superintendência-Geral, de atos de concentração com base em procedimento sumário. Diário Oficial da República Federativa do Brasil, Brasília, DF, 6 set. 2016. Disponível em: <https://www.jusbrasil.com.br/diarios/DOU/2016/09/06>. Acesso em: 5 dez. 2017.

BRASIL. Conselho Administrativo de Defesa Econômica. Resolução n. 20, de 07 de jun. de 2017. Aprova o Regimento Interno do Conselho Administrativo de Defesa Econômica. Boletim Interno CADE, Brasília, DF, 7 jun. 2017. Disponível em: <http://www.cade.gov.br/assuntos/normas-elegislacao/portarias/portaria70_2002.pdf/view>. Acesso em: 20 dez. 2017.

BRASIL. Conselho Administrativo de Defesa Econômica. Súmula n. 7, de 09 de dez. de 2009. Cooperativas Médicas. Diário Oficial da República Federativa do Brasil, Brasília, DF, 9 dez. 2009. Disponível em: $<$ http://www.cade.gov.br/assuntos/normas-e-legislacao/sumulas-docade/sumula-no-7-publicada-no-d-o-u-de-09-12-2009/view>. Acesso em: 20 dez. 2017.

BRASIL. Constituição (1988). Constituição da República Federativa do Brasil. 12.ed. São Paulo: Saraiva, 2016.

BRASIL. Constituição (1934). Constituição da República dos Estados Unidos do Brasil. Rio de Janeiro, 1934. Disponível em: 
<http://www.planalto.gov.br/ccivil_03/constituicao/constituicao34.htm>. Acesso em: 6 jan. 2018.

BRASIL. Decreto-Lei n ${ }^{\circ} 7.666$, de 22 de junho de 1945. Dispõe sobre os atos contrários à ordem moral e econômica. Diário Oficial da República Federativa do Brasil, Rio de Janeiro, Capital Federal, 22 de jun. 1945. Disponível em: <https://www.jusbrasil.com.br/diarios/2394956/pg-4-secao1-diario-oficial-da-uniao-dou-de-22-06-1945/pdfView?ref=next_button>. Acesso em: 5 jan. 2018.

BRASIL. Lei $n^{\circ}$ 4137, de 10 de setembro de 1962. Regula e repressão ao abuso do Poder Econômico. Diário Oficial da República Federativa do Brasil, Brasília, DF, 12 set. 1962. Disponível em: <http://www.planalto.gov.br/ccivil_03/leis/1950-1969/L4137.htm>. Acesso em: 9 dez. 2017.

BRASIL. Lei $\mathrm{n}^{\circ}$ 8.078, de 11 de setembro de 1990. Dispõe sobre a proteção do consumidor e dá outras providências. Diário Oficial da República Federativa do Brasil, Brasília, DF, 12 set. 1990. Disponível em: <http://www.planalto.gov.br/ccivil_03/Leis/L8078.htm>. Acesso em: 11 dez. 2017.

BRASIL. Lei ${ }^{\circ}$ 8.884, de 11 de junho de 1994. Transforma o Conselho Administrativo de Defesa Econômica (CADE) em Autarquia, dispõe sobre a prevenção e a repressão às infrações contra a ordem econômica e dá outras providências. Diário Oficial da República Federativa do Brasil, Brasília, DF, 13 jun. 1994. Disponível em: <http://www.planalto.gov.br/ccivil_03/leis/18884.htm>. Acesso em: 9 dez. 2017.

BRASIL. Lei $n^{\circ}$ 9.656, de 03 de junho de 1998. Dispõe sobre os planos e seguros privados de assistência à saúde. Diário Oficial da República Federativa do Brasil, Brasília, DF, 3 jun. 1998. Disponível em: <http://www.planalto.gov.br/ccivil_03/leis/L9656.htm>. Acesso em: 8 dez. 2017.

BRASIL. Lei $\mathrm{n}^{\mathrm{o}} 12.529$, de 30 de novembro de 2011. Estrutura o sistema brasileiro de defesa da concorrência. Diário Oficial da República Federativa do Brasil, Brasília, DF, 2 dez. 2011. Disponível em: <http://www.planalto.gov.br/ccivil_03/_ato2011-2014/2011/Lei/L12529.htm>. Acesso em: 10 dez. 2017.

BRASIL. Receita Federal. Instrução Normativa SRF n. 248, de 25 de novembro de 2002. Dispõe sobre a aplicação do regime de trânsito aduaneiro. Diário Oficial da República Federativa do Brasil, Brasília, DF, 27 nov. 2002. Disponível

em: 
<http://normas.receita.fazenda.gov.br/sijut2consulta/link.action?idAto=15125>. Acesso em: 15 dez. 2017.

BRASIL. Secretaria de Acompanhamento Econômico. Portaria n. 70, de 12 de dez. de 2002. Expede o Guia para análise econômica da prática de preços predatórios. Diário Oficial da República Federativa do Brasil, Brasília, DF, 13 dez. 2002. Disponível em: <http://www.cade.gov.br/assuntos/normas-elegislacao/regimento-interno/regimento-interno-do-conselho-administrativo-dedefesa-economica-13-06-17.pdf/view>. Acesso em: 8 dez. 2017.

BRASIL. Superior Tribunal de Justiça. Recurso Especial n. 1.181.643, da $2^{\mathrm{a}}$ Turma do Superior Tribunal de Justiça de 01 de março de 2011. Administrativo e concorrencial. Ação civil pública. Ordem econômica. Portos. Tarifa de armazenagem. Carga Pátio. Diário de Justiça Eletrônico, Brasília, DF, 20 maio 2011. Disponível em: <https://stj.jusbrasil.com.br/jurisprudencia/19086024/recurso-especial-resp1181643-rs-2010-0028927-4/inteiro-teor-19086025?ref=juris-tabs $>$. Acesso em: 15 dez. 2017.

BRASIL. Supremo Tribunal Federal. Súmula Vinculante n. 49, de 17 de junho de 2015. Ofende o princípio da livre concorrência lei municipal que impede a instalação de estabelecimentos comerciais do mesmo ramo em determinada área. Diário Oficial da República Federativa do Brasil, Brasília, DF, 23 jun. 2015. Disponível em: <http://www.stf.jus.br/portal/jurisprudencia/menuSumario.asp?sumula=2506>. Acesso em: $20 \mathrm{dez} .2017$.

CONSELHO ADMINISTRATIVO DE DEFESA ECONÔMICA. Averiguação preliminar n. 08012.007155/2008-13 vol. 1, de 19 de dez. de 2014. ZF Serviços Ltda v. Associação dos Centros Comerciais Atacadistas de Santa Catarina (ACECOMVI). Disponível em: <https://bit.ly/2KB6ilB>. Acesso em: 5 dez. 2017.

CONSELHO ADMINISTRATIVO DE DEFESA ECONÔMICA. Procedimento preparatório n. 08700.00.009890/2014-43 vol. 1, de 20 de nov. de 2014. Cade ex officio v. Unimed Missões. Disponível em: <https://bit.ly/2INwThT>. Acesso em: 20 dez. 2017.

CONSELHO ADMINISTRATIVO DE DEFESA ECONÔMICA. Procedimento preparatório n. 08700.00.009890/2014-43 vol. 1, de 20 de nov. de 2014. Cade ex officio v. Unimed Missões. Disponível em: <https://bit.ly/2INwThT>. Acesso em: 20 dez. 2017.

CRISTOFARO, Pedro Paulo Salles. As cláusulas de raio em shopping centers e a proteção à livre concorrência. Revista do IBRAC, São Paulo, vol. 10, n. 3, dez. 2003. Disponível em: 
<http://www.ibrac.org.br/UPLOADS/PDF/RevistadoIBRAC/Revista10n3.pdf> . Acesso em: 7 dez. 2017.

FILHO, José dos Santos Carvalho. Manual de Direito Administrativo. 30.ed. São Paulo: Atlas, 2016. 1.331 p.

FORGIONI, Paula Andréa. Os fundamentos do antitruste. 7.ed. São Paulo: Revista dos Tribunais, 2014. 491p.

HOVENKAMP, Herbert. Antitrust. 4.ed. Minnesota: Thomson West, 1986. (Black Letter Outlines).

INSTITUTO BRASILEIRO DE ESTUDOS DE CONCORRÊNCIA, CONSUMO E COMÉRCIO INTERNACIONAL. 5 anos Lei de Defesa da Concorrência: gênese, jurisprudência e desafios para o futuro. São Paulo: IBRAC, out. 2017. 394 p. Disponível em: <http://www.ibrac.org.br/UPLOADS/Livros/arquivos/5_ANOS_DE_LEI_ DA_CONCORR\%C3\%8ANCIA_-_IBRAC.pdf>. Acesso em: 5 dez. 2017.

McCLAVE, James T.; BENSON, P. George; SINCICH, Terry. Statistics for business and economics. 8.ed. Upper Saddle River: Prentice-Hall, 2001. $1.028 \mathrm{p}$.

NEGRÃO, Ricardo. Manual de Direito Comercial e de Empresa. 12.ed. São Paulo: Saraiva, 2015. 578 p.

NETO, Caio Mário da Silva Pereira; CASAGRANDE, Paulo Leonardo. Direito Concorrencial. São Paulo: Saraiva, 2016. 512 p.

PEDREIRA, José Luiz Bulhões; FILHO, Alfredo Lamy. Direito das Companhias. 2.ed. Rio de Janeiro: Forense, 2017. 1.614 p.

RIO GRANDE DO SUL. Conselho de Autoridade Portuária Porto Rio Grande. Regulamento de Exploração do Porto do Rio Grande. Disponível em: <http://www.portoriogrande.com.br/site/autoridade_portuaria_legislacao.php>. Acesso em: 13 dez. 2017.

SILVA, José Afonso. Curso de Direito Constitucional Positivo. 38.ed. São Paulo: Malheiros Editores, 2015. 936 p.

UNIÃO EUROPEIA. Tribunal Geral, Acórdão Processo n. T-208/13 de 28 de julho de 2016. Jornal Oficial da União Europeia, Luxemburgo, LX, 08 ago. 2016. Disponível em: <https://publications.europa.eu/pt/publicationdetail/-/publication/f53f0c17-5d2d-11e6-89bd-01aa75ed71a1/language-pt $>$. Acesso em: 23 dez. 2017. 
UNIMED MISSÕES. Código de Conduta Unimed Missões. Aprimora os relacionamentos internos, externos e princípios que norteiam a conduta de colaboradores, dirigentes, cooperados que ocupam cargos administrativos e plantonistas, perante suas partes interessadas. Santo Ângelo, 2002. Disponível em: <http://www.unimedmissoes.com.br/materialsite/codigodeconduta2014.pdf >. Acesso em: 17 dez. 2017.

UNITED STATES OF AMERICA. Sherman Anti-Trust Act, de 2 de julho de 1890. Protect trade and commerce against unlawful restraints and monopolies. Presidência dos Estados Unidos da América, Washington, DC, 2 dez. 1890. Disponível em: $<$ https://www.ourdocuments.gov/doc.php?flash=false \&doc=51\&page=trans cript>. Acesso em: 30 nov. 2017.

WHISH, Richard. Competition Law. 6.ed. New York: Oxford University Press, 2009. 